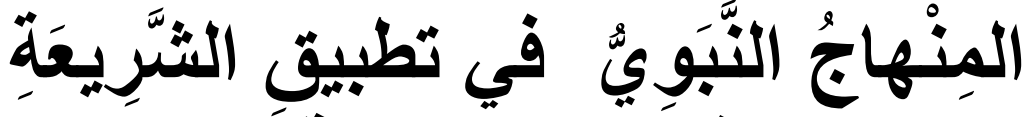 في ضوء السنة
}

إعداد :

الدكتور / محمد عيد عبد العزيز أبو كُرَيّمٍ المدرس بقسم الحديث بالكلية

$$
\text { لعام (2015) }
$$




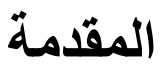

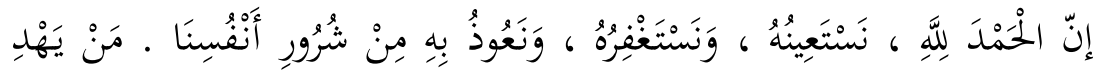

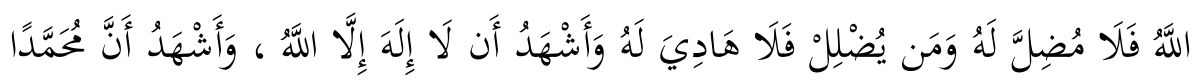

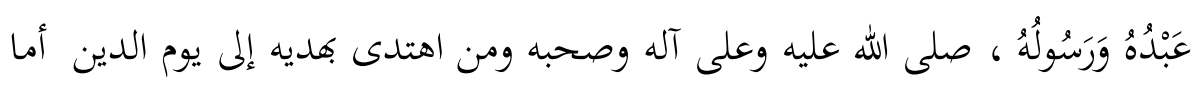
:

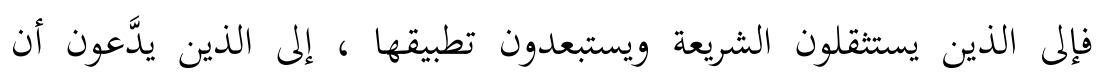

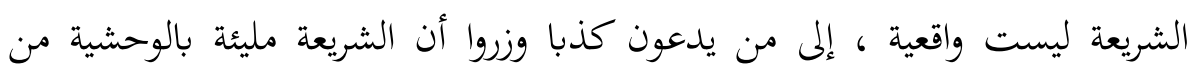

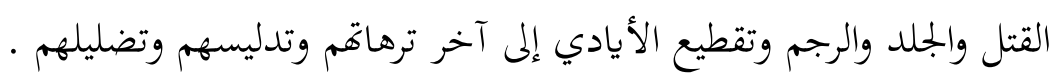

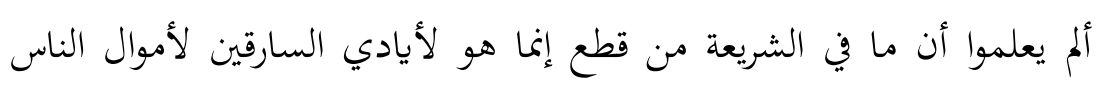

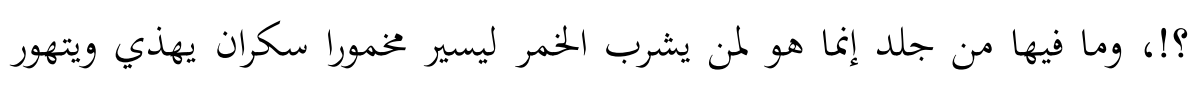

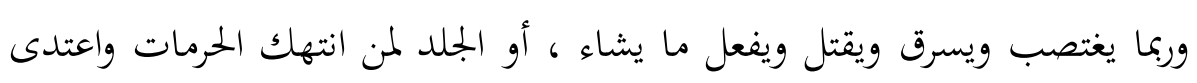

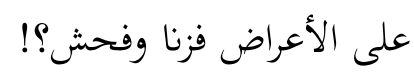

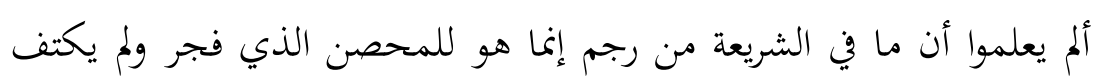

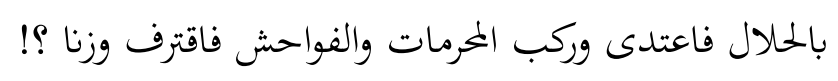

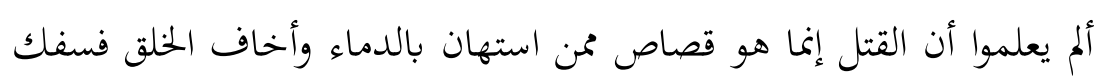

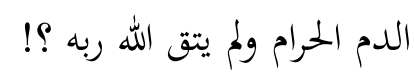

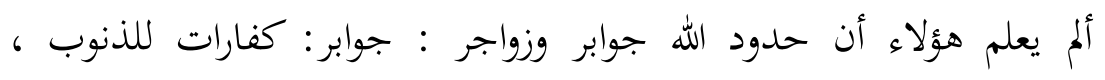

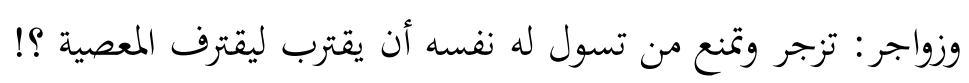

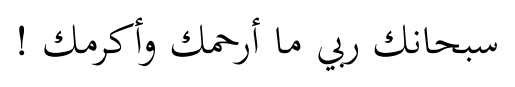

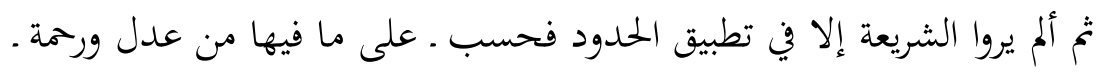

ألم يروها في صلاة تريح قلوبًا، وفي صوم يعين على تقوى، وفي زكاة تطهر مالًا، 


$$
\text { وفي حج يغسل ذنوبًا ؟! }
$$

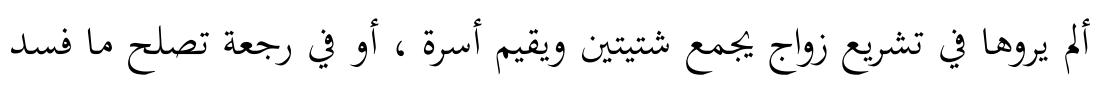

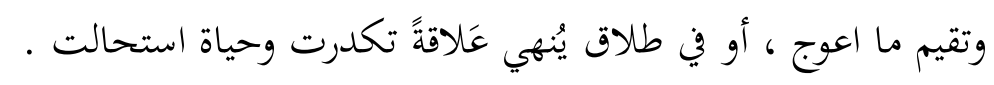

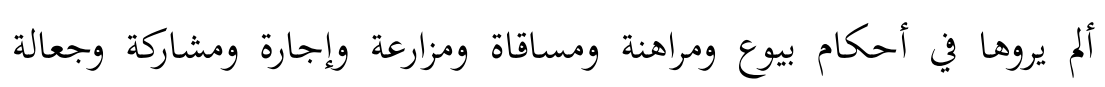

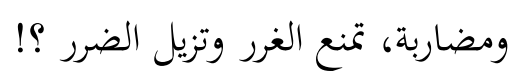

ألم يروها في أحكام عقيقة وأضحية ووديعة وعارية وشفعة وحوالة ولقطة وكفالة

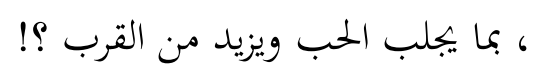

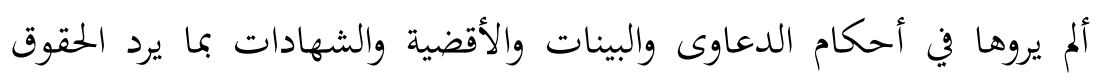

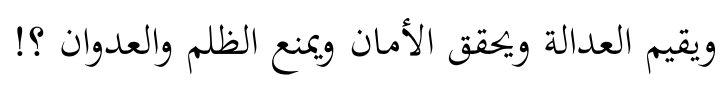

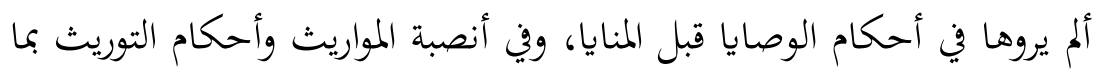

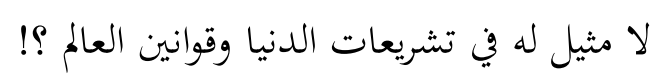

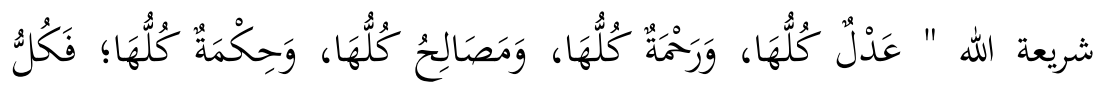

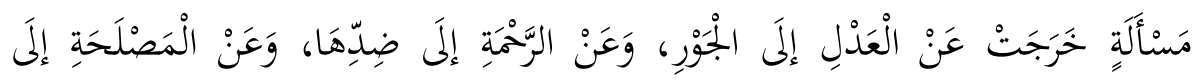

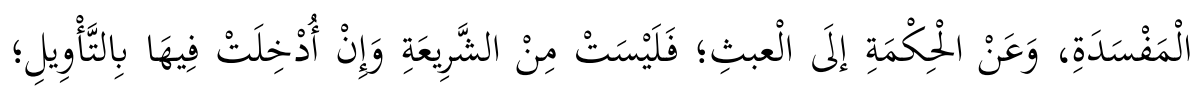

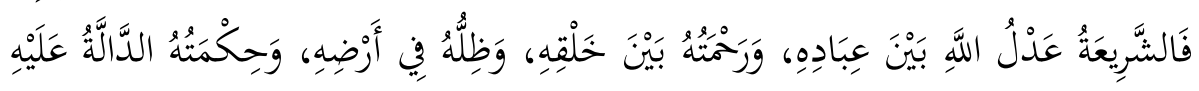

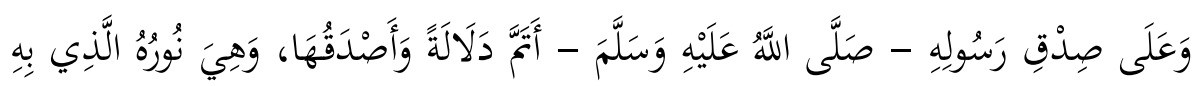

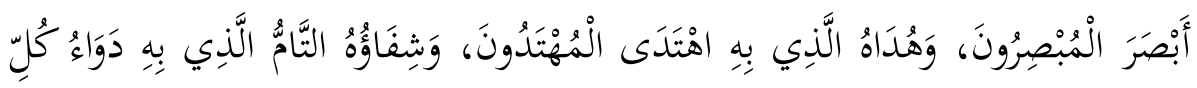

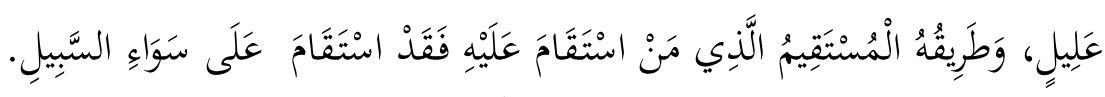

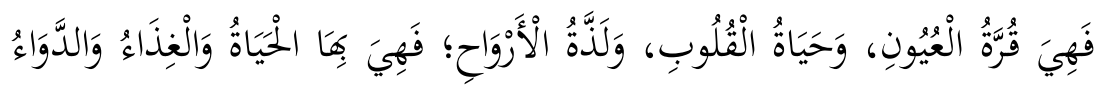

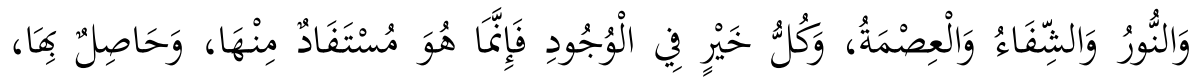

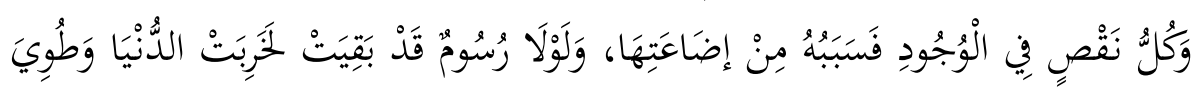
الْعَالََ.

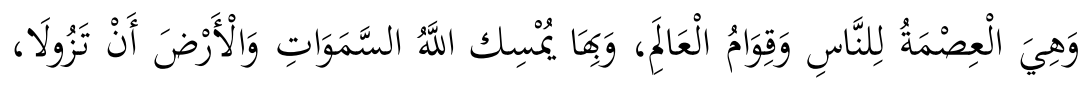




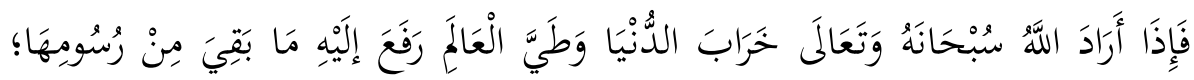

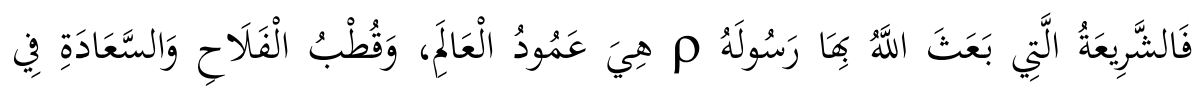

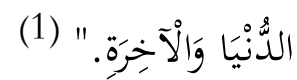

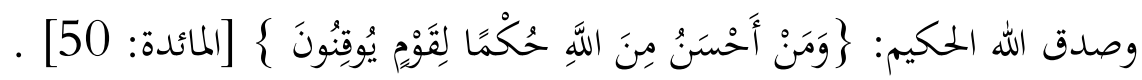

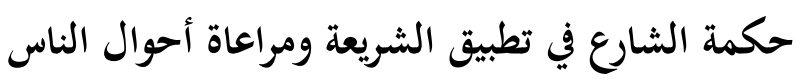

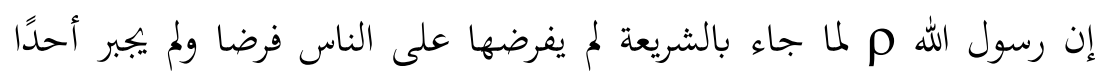

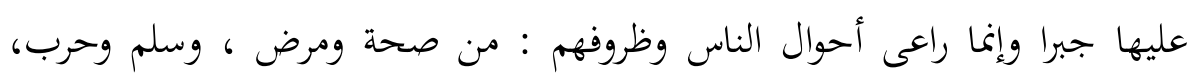

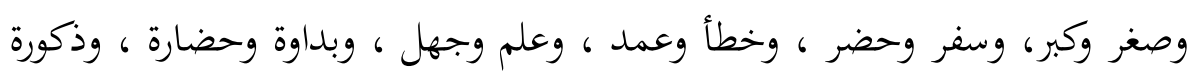
وأنوثة . ومغر وكرن.

كما أنه راعى ظروف المكان والزمان وقدر لكل قدره ، فكانت الشريعة صالحة

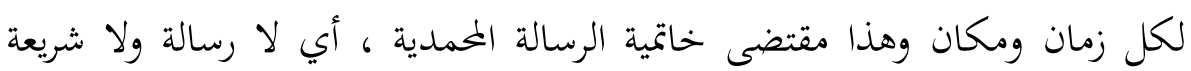

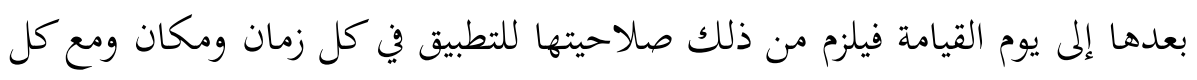

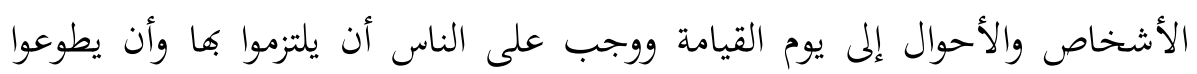

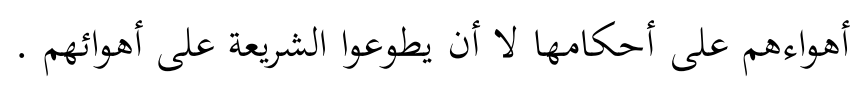

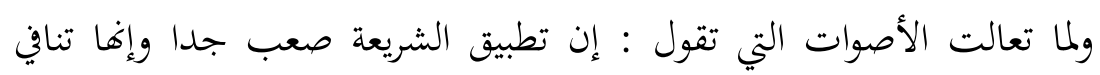

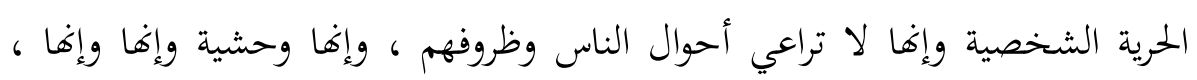

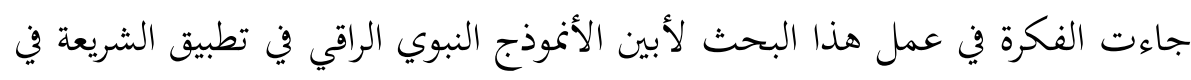

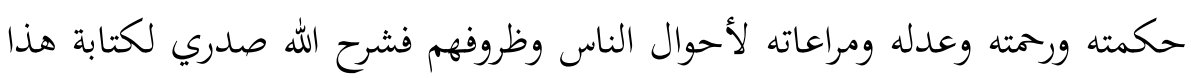

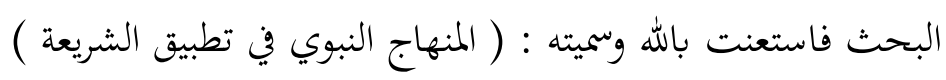

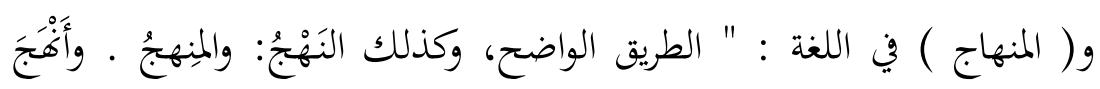

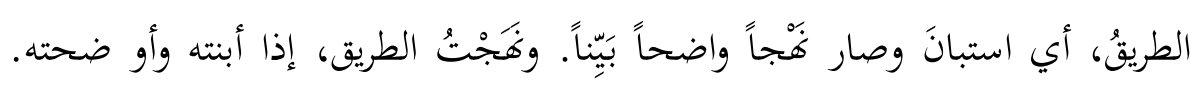




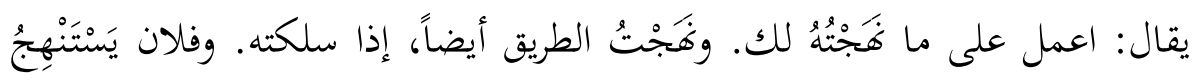

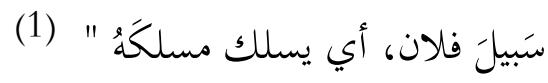

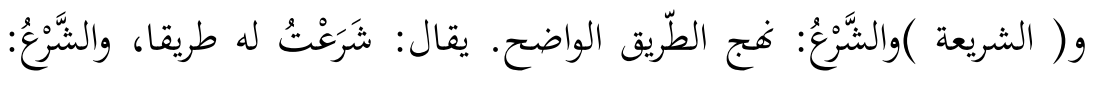

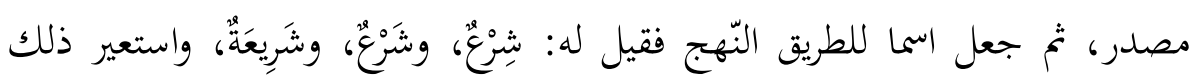

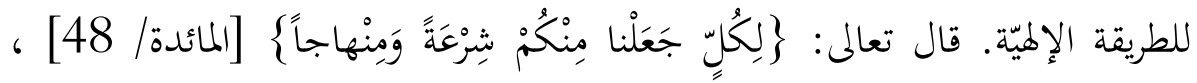

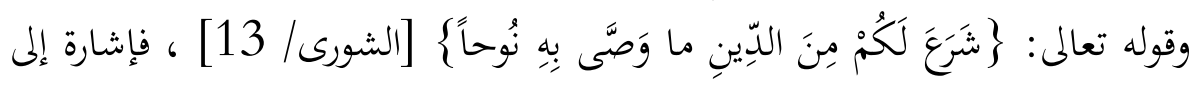

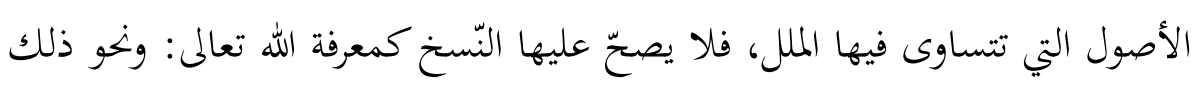

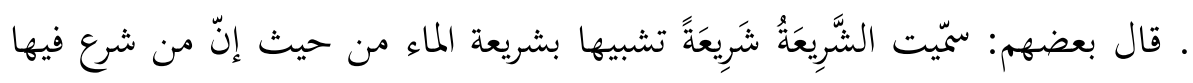
على الحتيقة المصدوقة روي وتطهّر . مان.

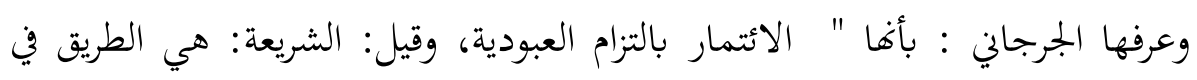

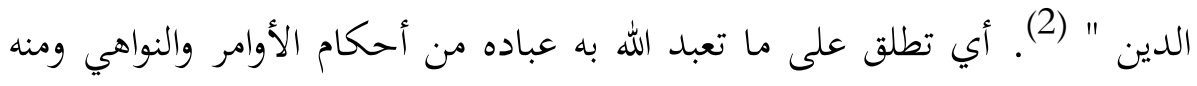
حديث طلحة بن عبيد الله في قصة الأعرابي السائل عن الصلاة والصوم والزكاة وفيه:

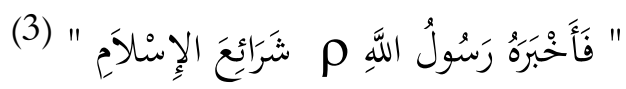
وقصدت بالعنوان : المنهاج البين والطريقة الواضحة المكيمة الرحيمة التي سلكها النبي

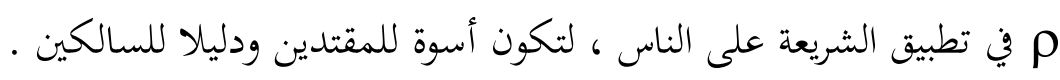

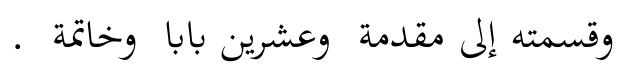
أما المقدمة فذكرت فيها سبب تأليف البحث والتعريف بعفردتي البحث ومنهجي فيه وتقسيمه

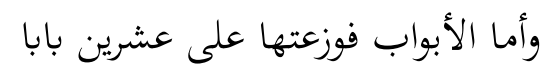

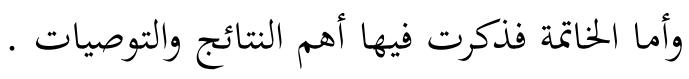

$$
\text { (1) التعريفات للجرجاني (ص: 127 1276) . }
$$

(3) البخاري :كتاب الصوم باب وجوب صوم رمضان (3/ (27 24 رقم 1891 ) . 


\section{منهجي في البحث :}

1 ـ ذكرت تحت كل باب غالبا ما يناسبه من آيات قرآنية اقتداء بالأئمة

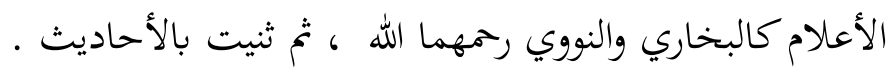

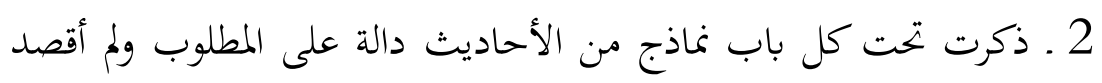

الحصر مخافة الطول .

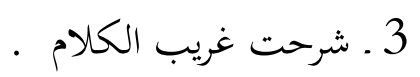

4 ـ ثم ذكرت فوائد مناسبة لترجمة الباب مستقاة من الأحاديث المذكورة.

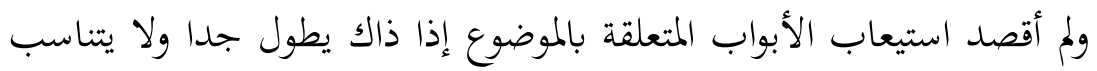

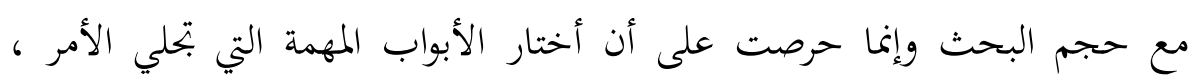

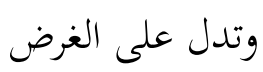

وكل باب حقيق بأن يفرد ببحث مستقل تكثر فيه الأحاديث الصحيحة

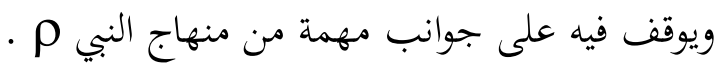

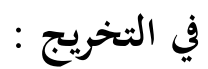

1 ـ أقدم في التخريج الكتب الستة ثم أرتب من بعدهم الأعلى فالأعلى إسنادا

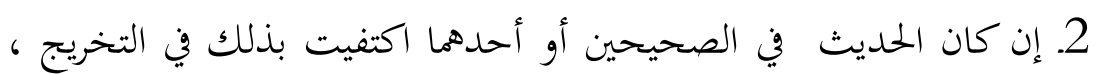

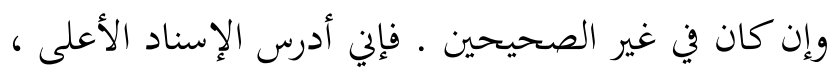

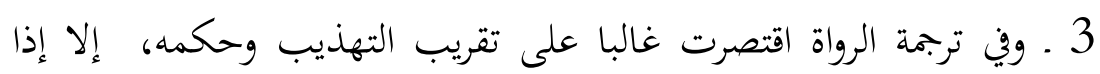

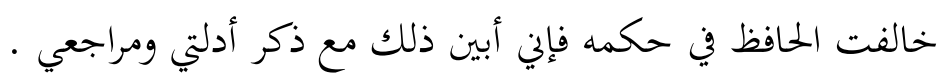

وأسأل الله تعالى أن ينفعني والمسلمين به إنه ولي ذلك ومولاه وهو على كل

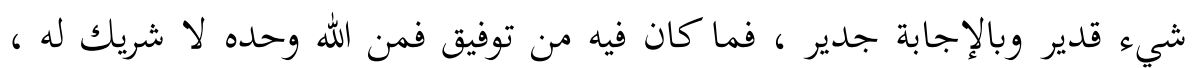

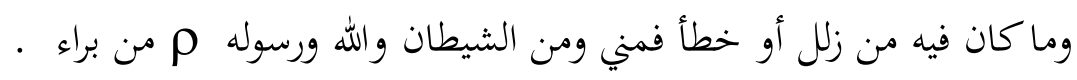

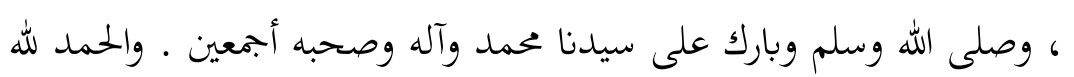


رب العالمين 


\section{باب (1) في تيسير الببي م وتخفيفه على الأمة}

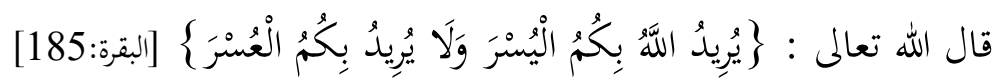

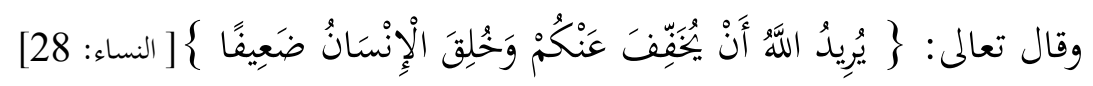

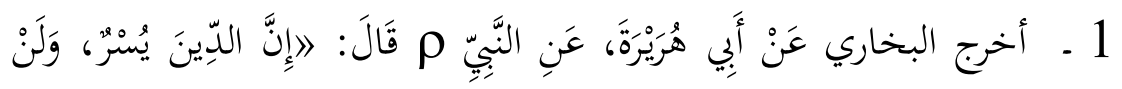

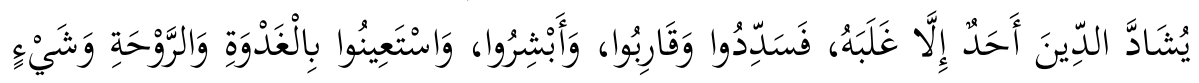

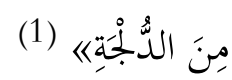

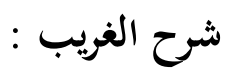

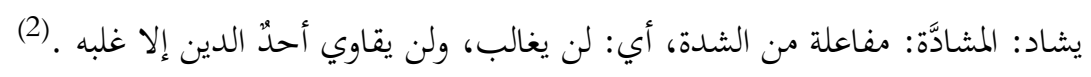

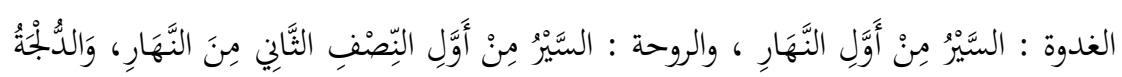

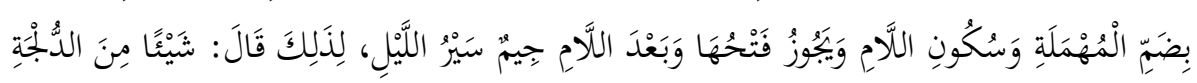

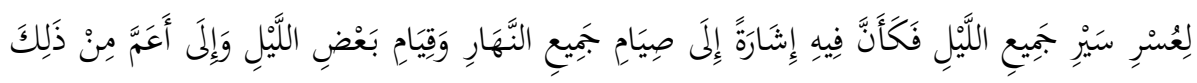

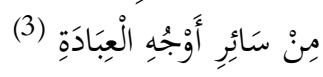

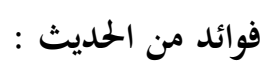

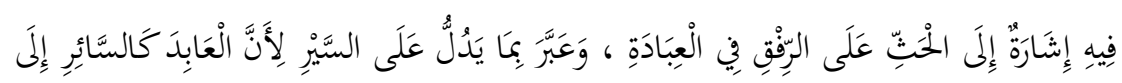

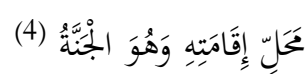

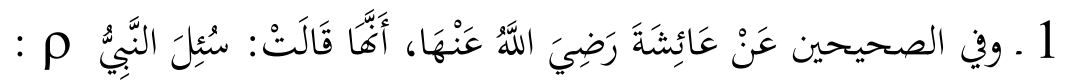

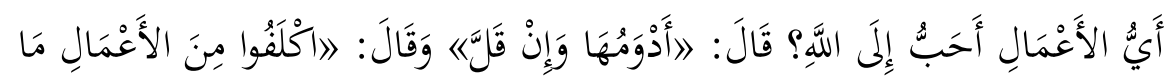
تُطِيقُونَه(5) واللفظ للبخاري

شرح الغريب : ون

$$
\begin{aligned}
& \text { البخاري كتاب الإيمان باب الدين يسر (1/ 16 (16) رقم } 39 \text { (1) }
\end{aligned}
$$

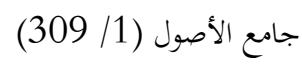

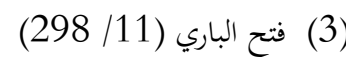

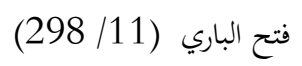

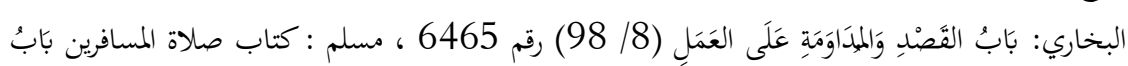

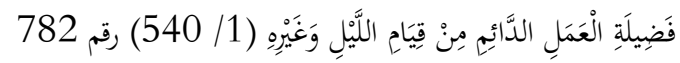




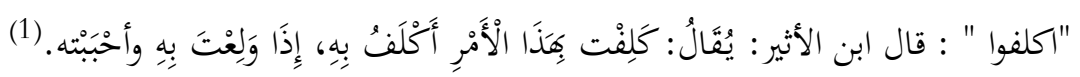

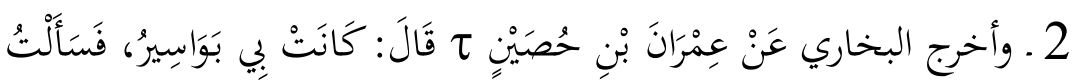

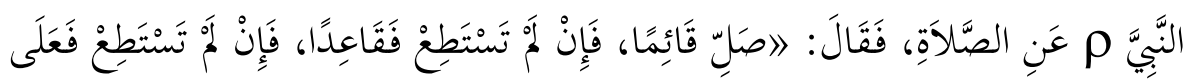

(2)

3 ـ وفي الصحيحين عن أبي مسعود الأنصاري أَنَّ رَجْلًا، قَالَ: وَاللَّهِ يَا رَسُولَ اللَّهِ

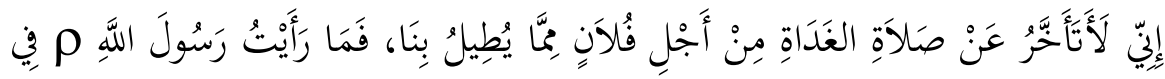

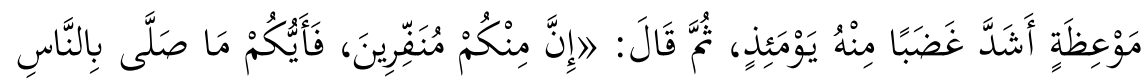

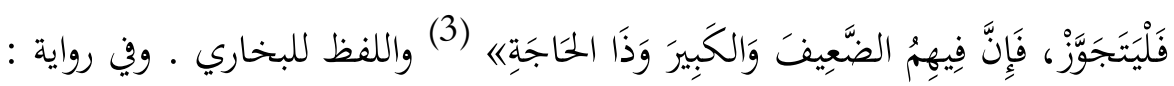

$$
\begin{aligned}
& \text { " فليخفف " . } \\
& \text { شرح الغريب : ( ) : }
\end{aligned}
$$

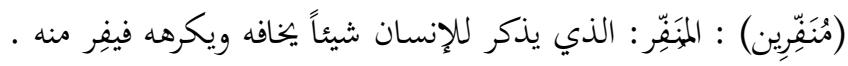

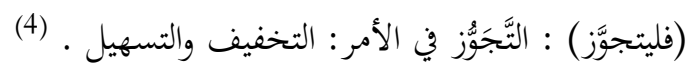

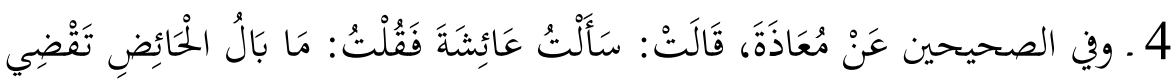

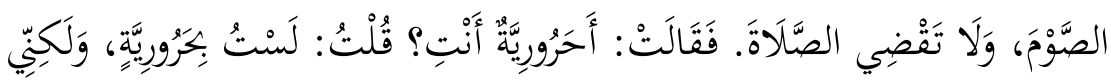

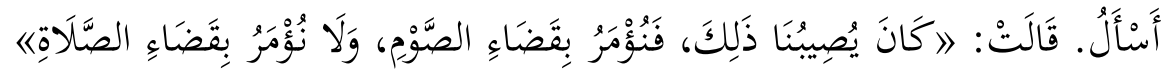

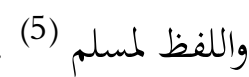

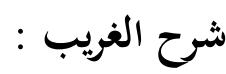

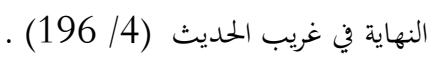

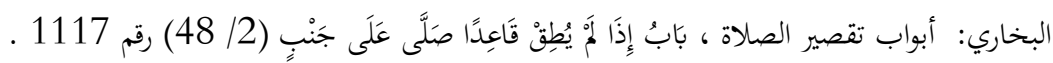

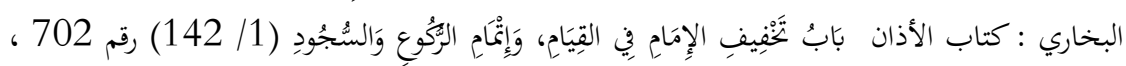

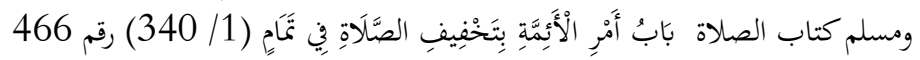

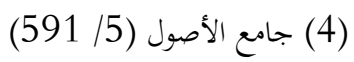

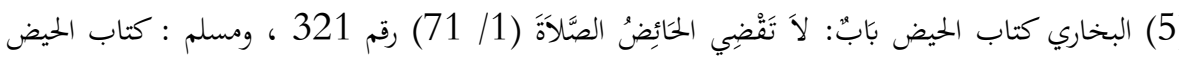

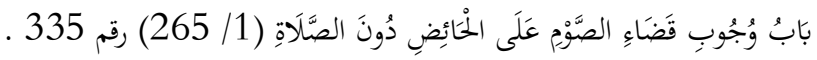


(أَحَرُورِِّّة؟) الحرورية: طائفة من الحوارج نزلوا قرية تسمى حَرُوراء، كان أول اجتماعهم وتعاهدهم

وقولها لها: أحرورية أنت؟) تريد : أغها خالفت السُّنَّ، وخرجت عن الجماعة، كما خرج أولكك عن جماعة المسلمين. وقيل: إنها شبهتها في سؤالها وتعنتها فيه بالحروريَّة، فإنهم يكثرون المسائل، ويتعنَّون الناس بما

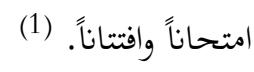

\section{باب (2) رفع الحرج والمشقة عن الأمة}

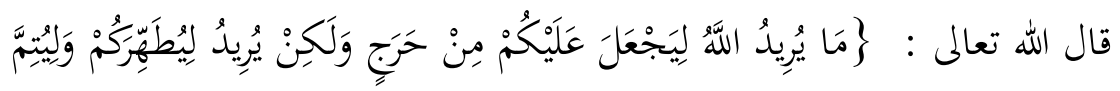

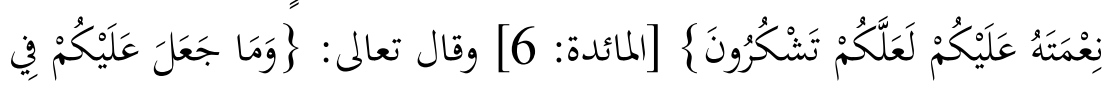

الدّيّنِ مِنْ حَرَجِ $\{$ [الحج:

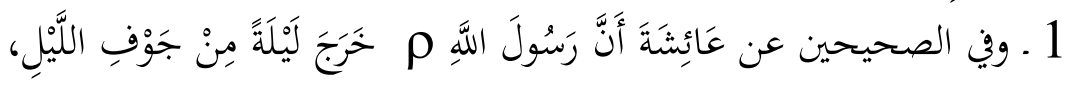

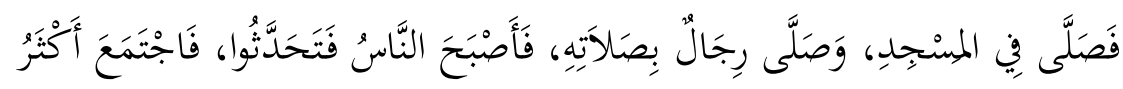

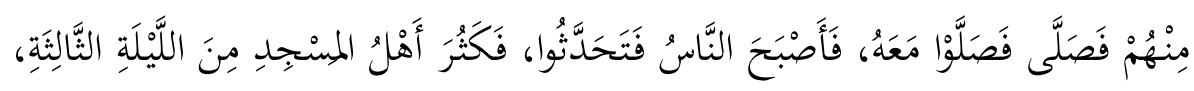

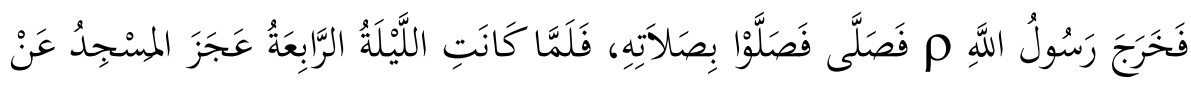

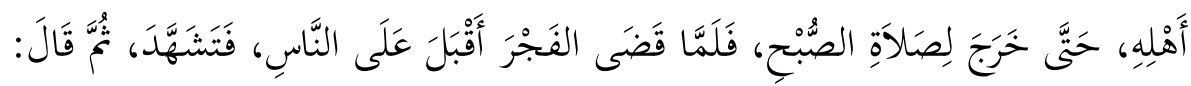

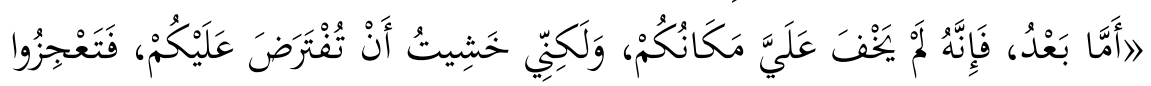
عَنْهاها (2) واللفظ للبخاري .

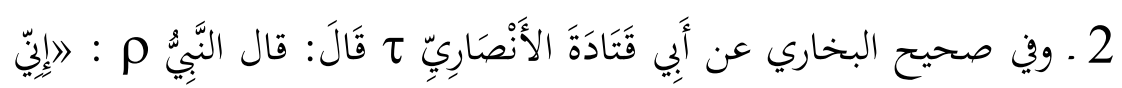

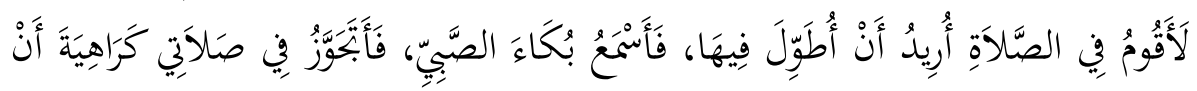

(2) البخاري كتاب صلاة التراويح باب فضل من قام رمضان (357) ـ 45 45 ) رقم 2012 ـ ومسلم كتاب صلاة

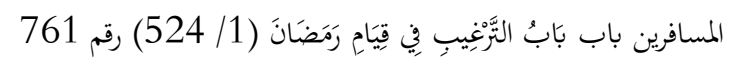




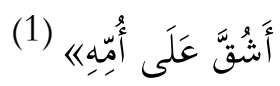

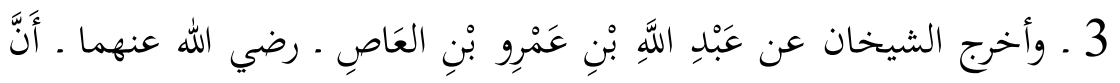

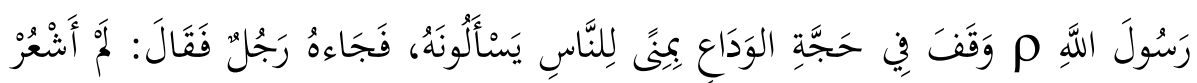

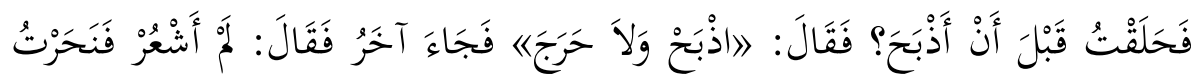

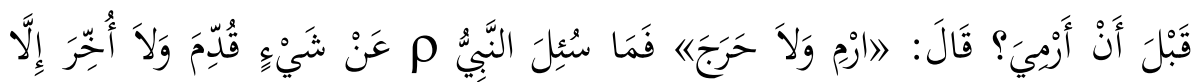

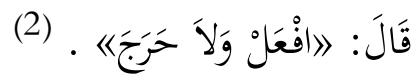

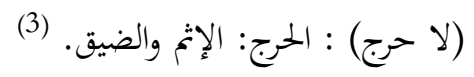

\section{باب (3) في التدرج في التشريع}

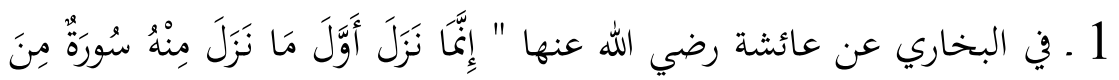

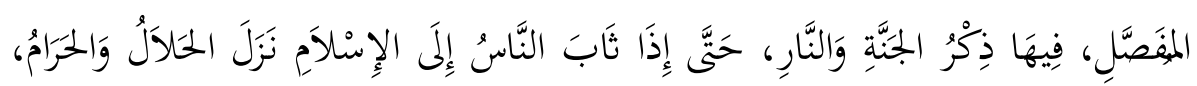

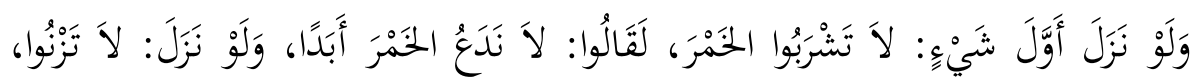

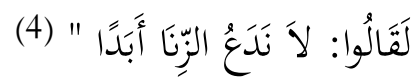

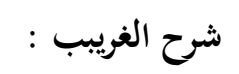

( المفصل ) : السور القِصار . سميت مفصلاً، لكثرة الفصول بينها بالبسملة . (5) وفي تحديد

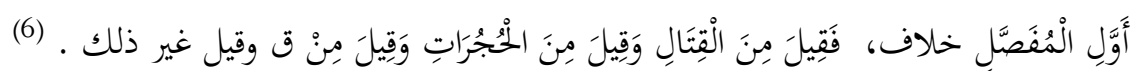

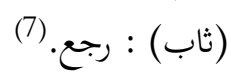

فوائد من الحمديث :

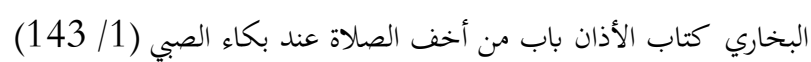

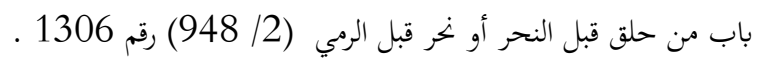

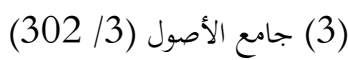

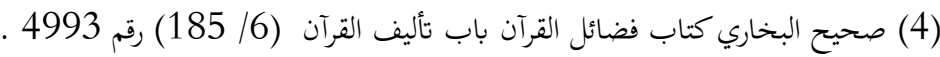

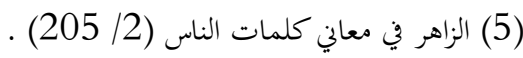

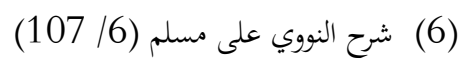

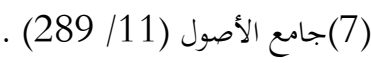




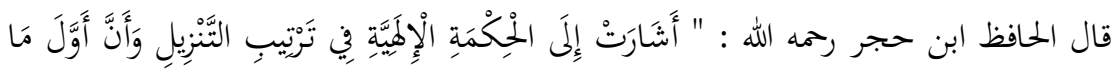

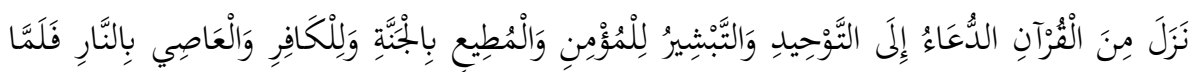

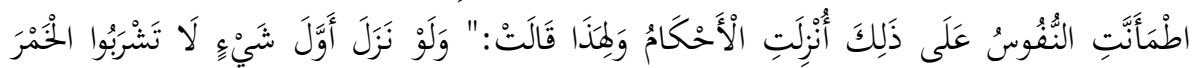

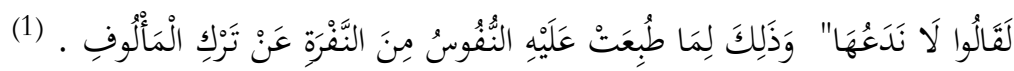

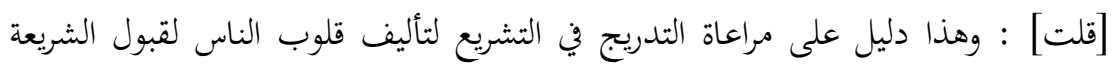

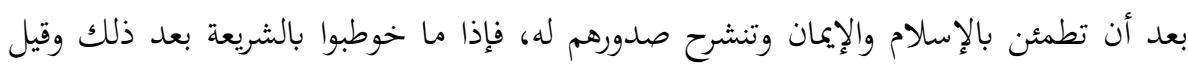

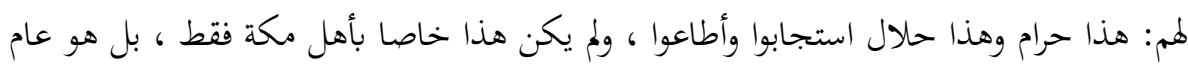

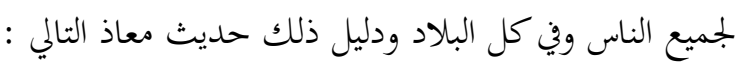

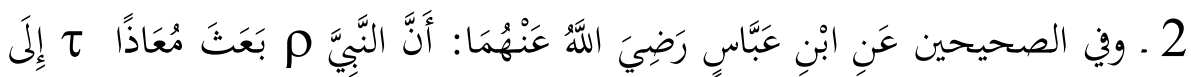

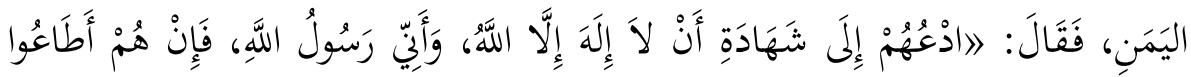

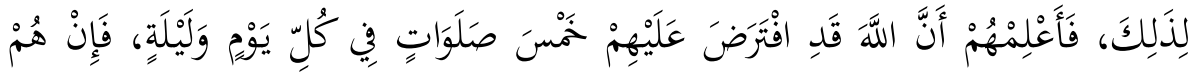

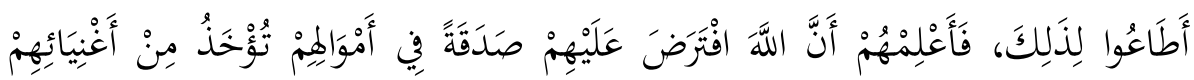

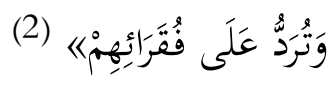

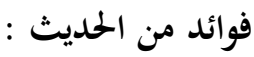

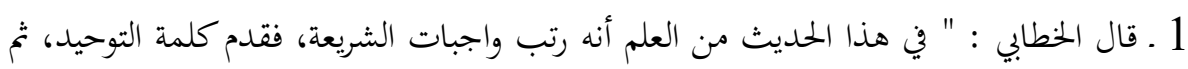

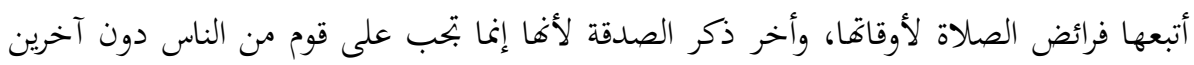

2 ـ وفيه التدرج في تطبيق الشريعة فلم يلزمهم بها دفعة واحدة ، وإنما أمرهم بالتوحيد فإذاذا

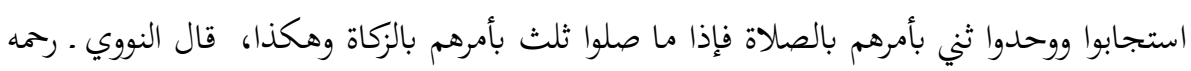

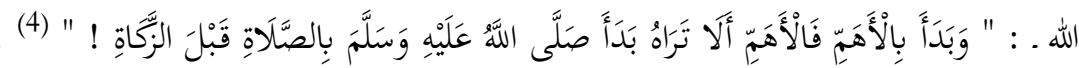

$$
\text { (1)فتح الباري لابن حجر (9/9/ 40) . }
$$

(2) البخاري كتاب الزكاة باب وجوب الزكاة (2/ 104) (10) رقم 1395 ، ومسلم كتاب الإيمان باب الدعاء إلى

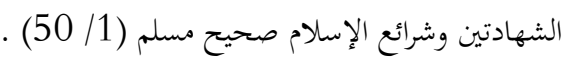

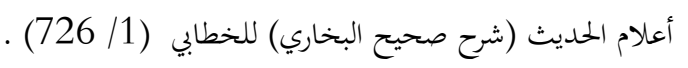

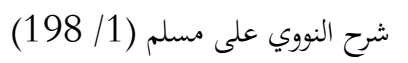




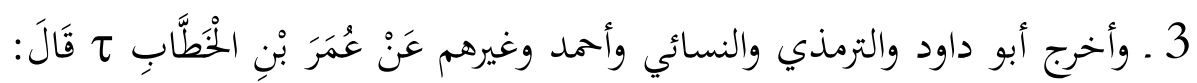

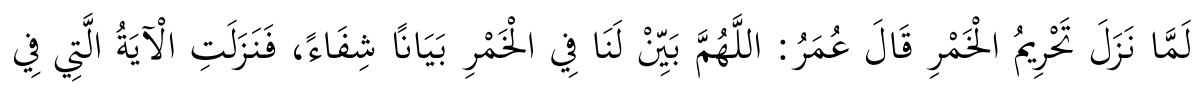

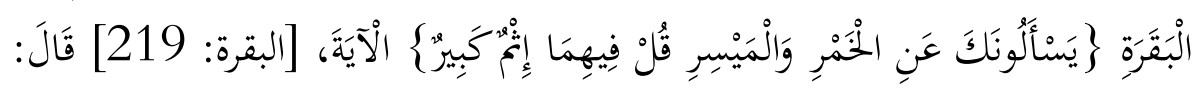

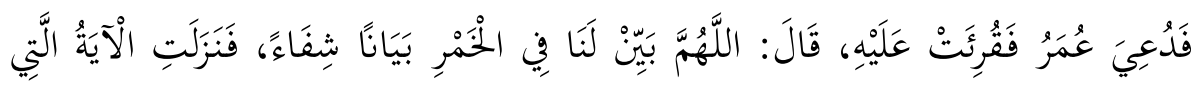

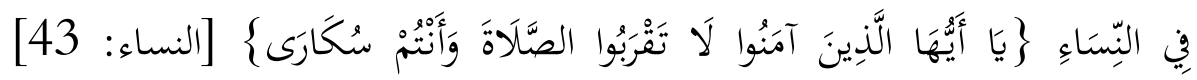

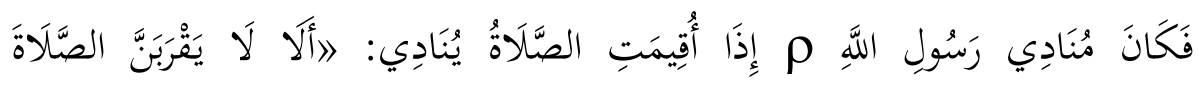

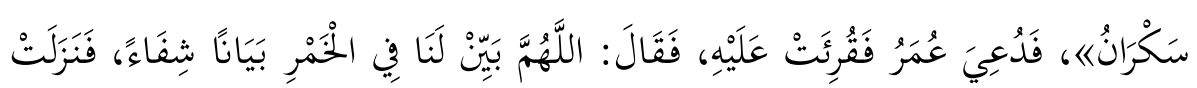

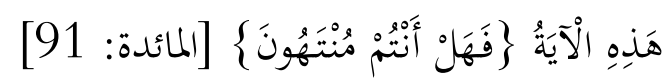

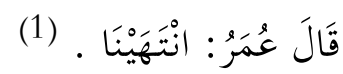

(1) أخرجه أبو داود في سنه ، واللفظ له :كتاب الأشربة باب في تريمع الخمر (5/ 514) رقم 670 : حدَّثنا

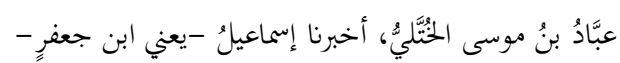

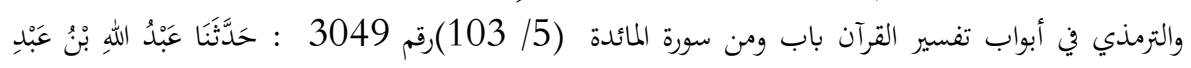

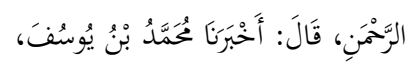

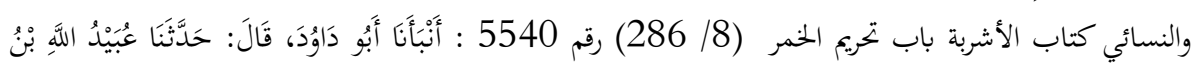

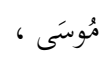

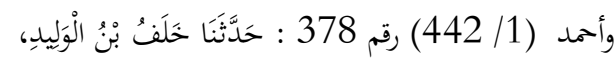

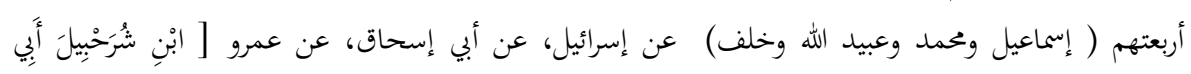

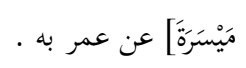

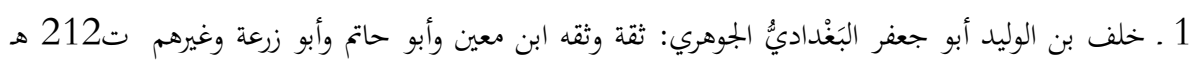

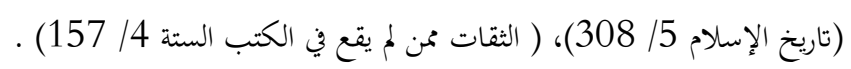

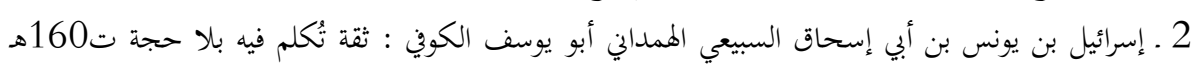

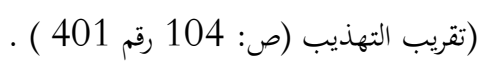

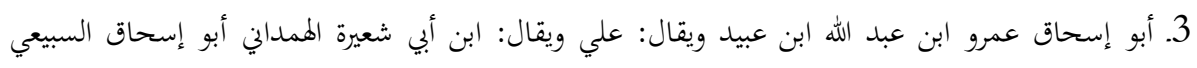

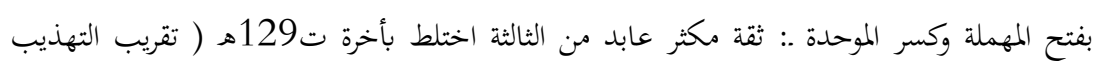
ص: 423) رقم 5065 . . ) 


\section{شرح الغريب}

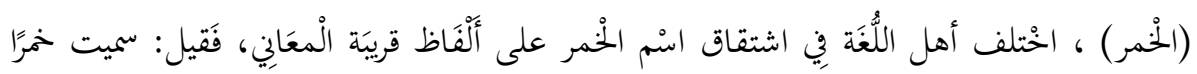

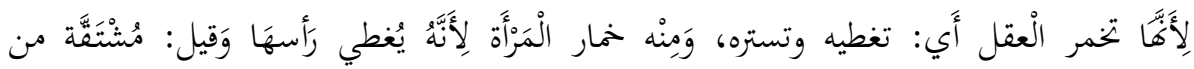

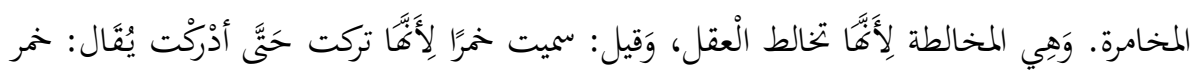

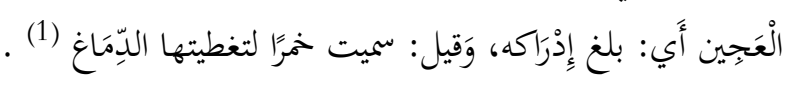

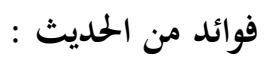

في الحديث بيان تطبيقي لقضية التدرج في التشريع وذلك بمرور تحريم الخمر بثلاث

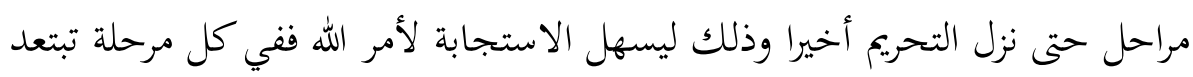

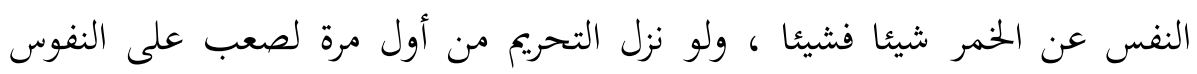

[قلت]:وسماع حفيده يونس منه صحيح فهو من أصحابه الملازمين الثقات ، وقد تعقب العراقيُّ ابنَ الصلاح في

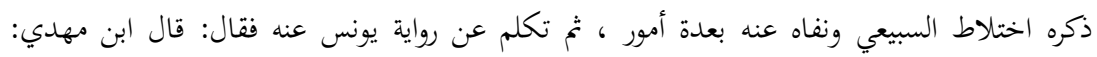

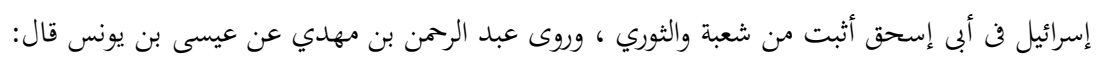

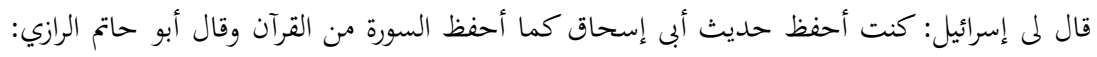

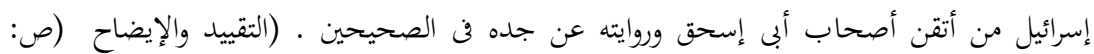

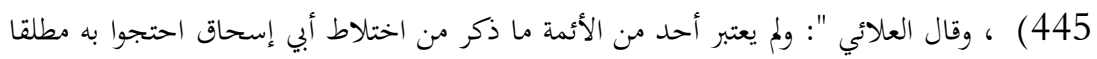

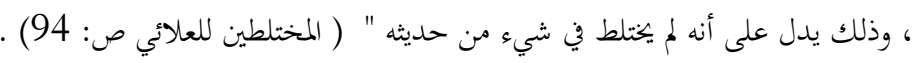

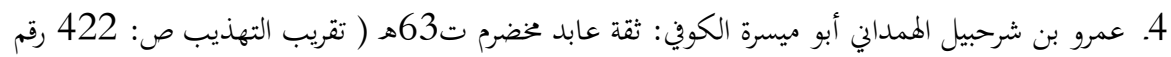

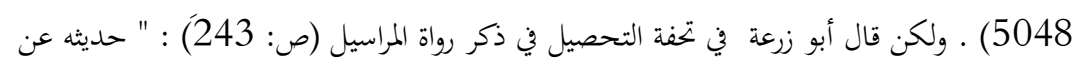

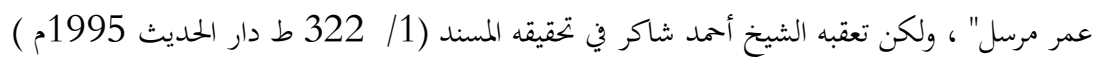

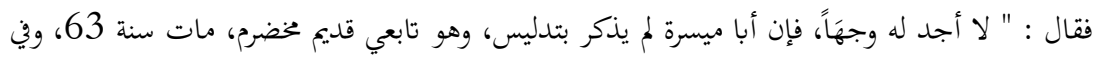

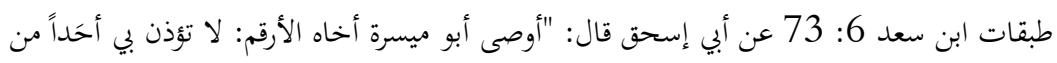

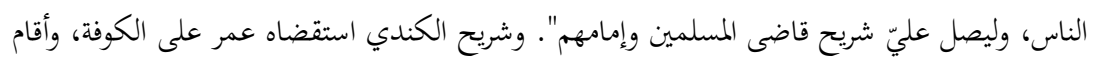

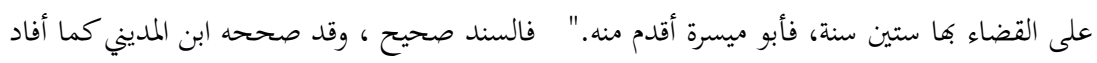

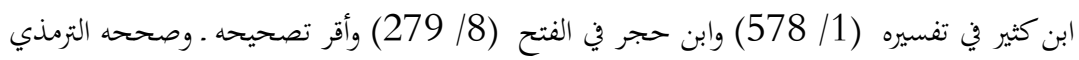

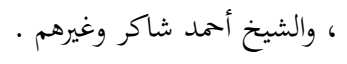

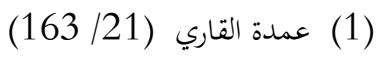


باب (4) في رحمة النبي م ورفقه بالمخطئين والجاهلين الأحكامَ والآدابَ

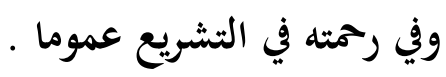

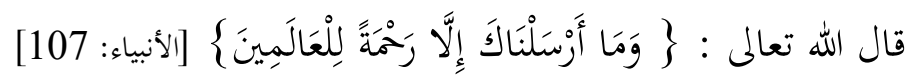

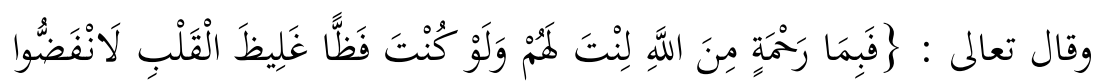

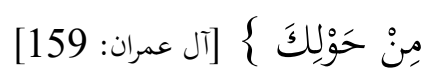

1 ـ في الصحيحين واللفظ لمسلم عن أَنَسِ بْنِ مَالِكٍ ، قَالَ: بَبْنَمَا نَنْنُ فِي

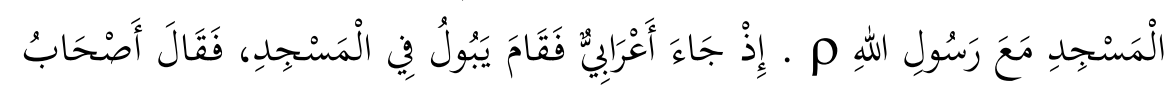

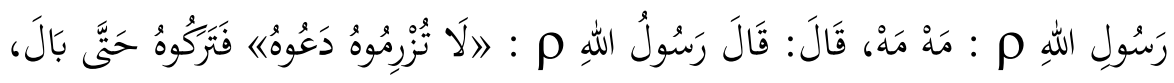

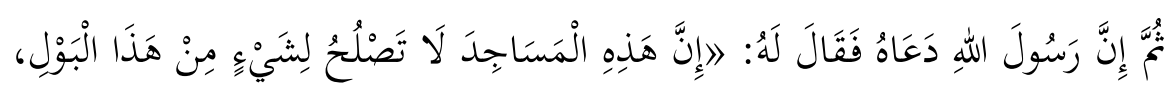

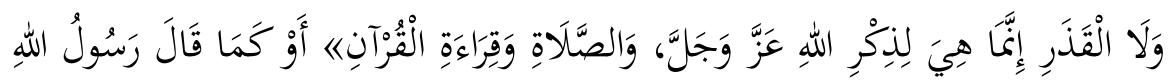

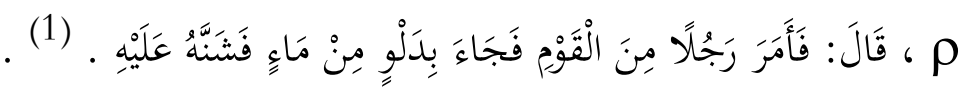

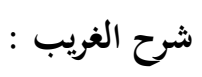

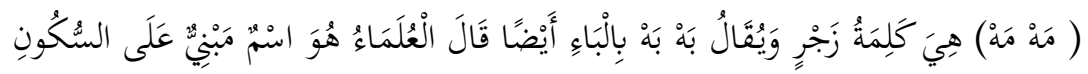

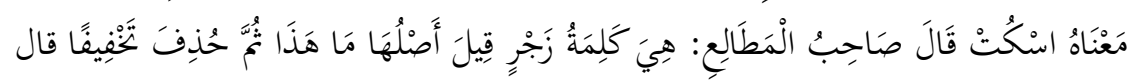

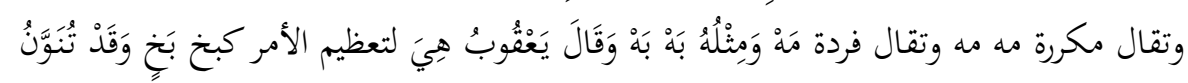

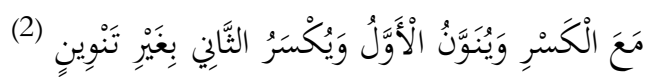

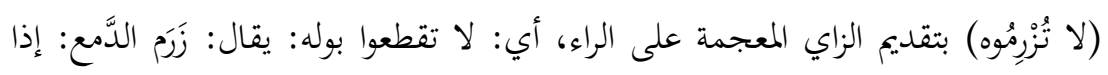

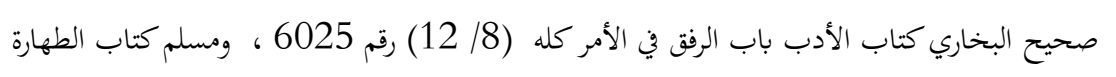

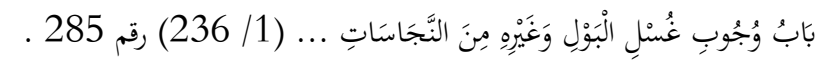

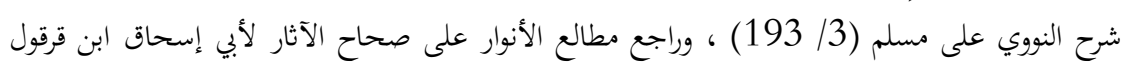


(فسنَّه عليه) سنتت الماء على الثوب وعلى الأرض ونو ذلك: إذا صبيته عله، وقد جاء

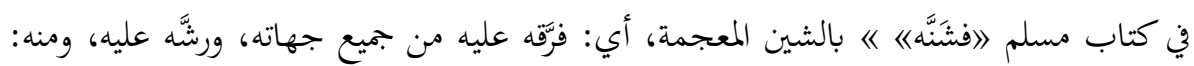

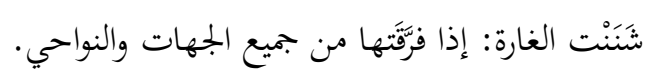

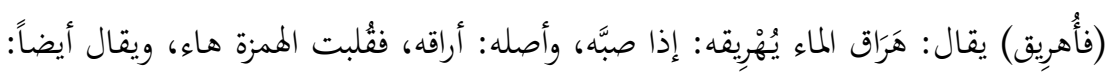

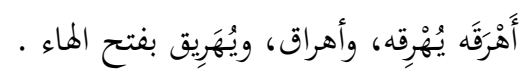

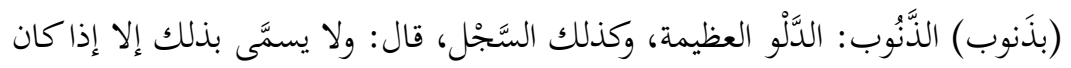

فيها ماء. (1)

$$
\text { فال الإمام النووي رممه الله : فيث }
$$

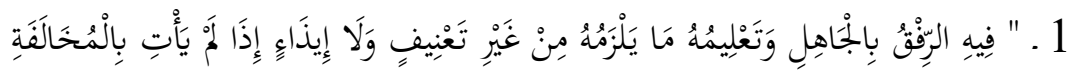

اسمتِخْفَفا أَوْْ عِنَادًا

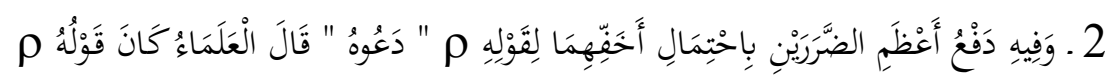

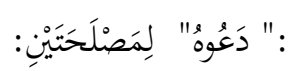

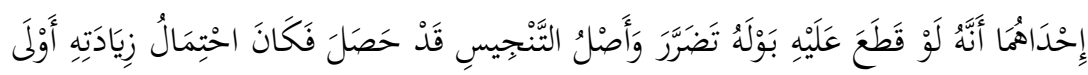

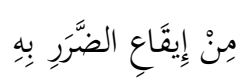

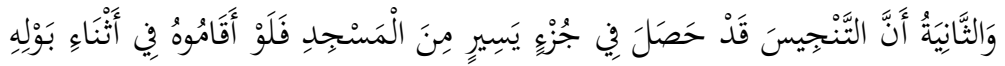

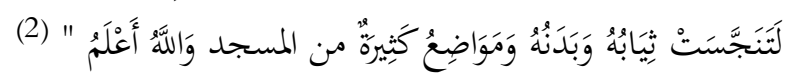

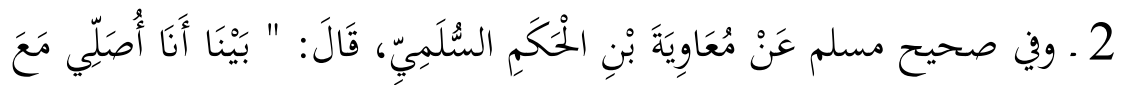

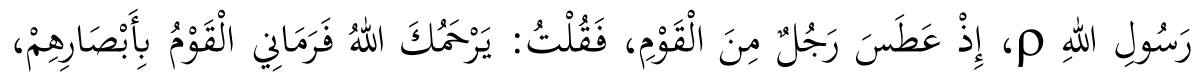

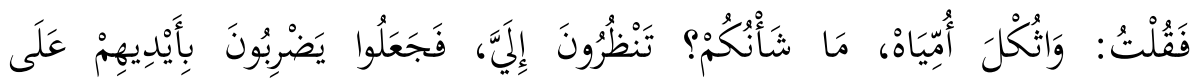

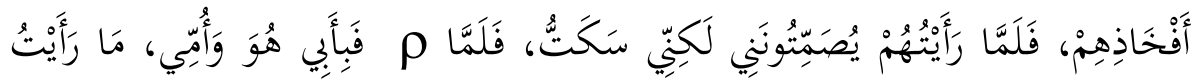

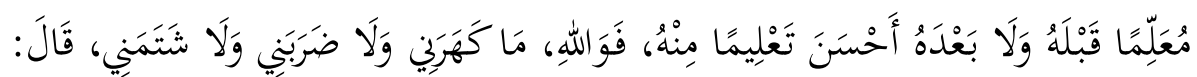

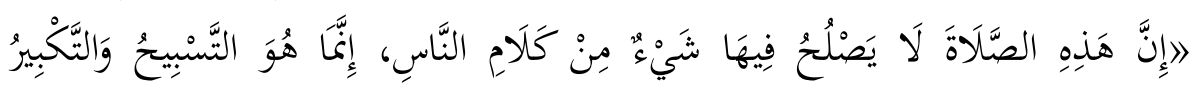

$$
\text { (2) شرح النووي على مسلم (17/ (17 191) }
$$




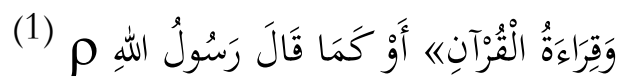

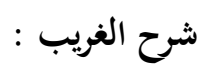

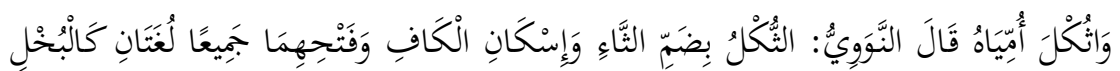

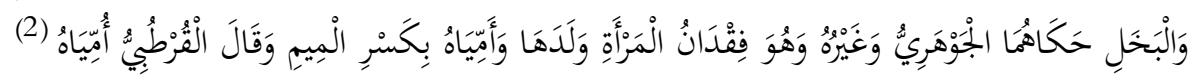

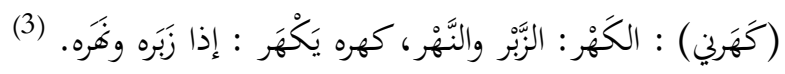

$$
\text { فوائد من الحديث : }
$$

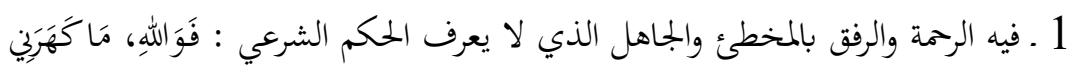

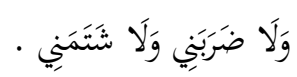

$$
\text { 2 } 2 \text { وفيه حسن تعليم الجاهل وتأدييه بلين الكلام . }
$$

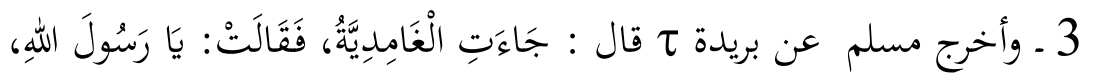

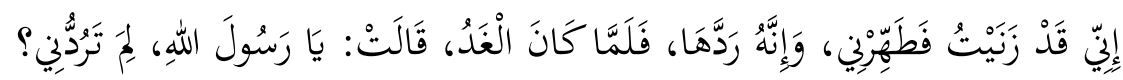

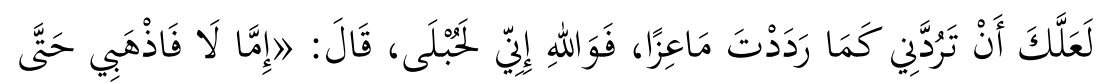

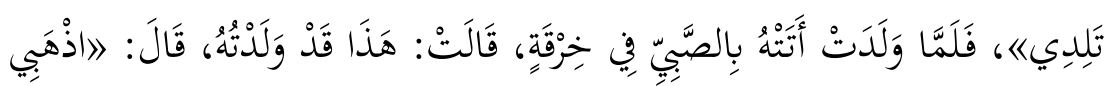

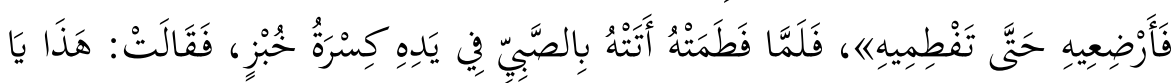

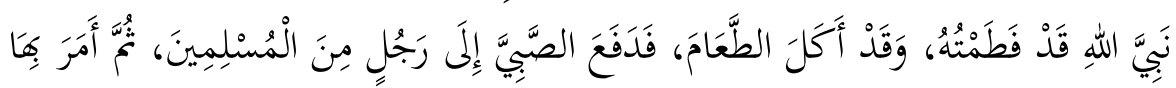

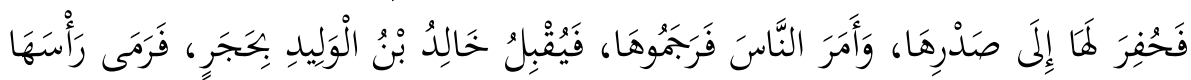

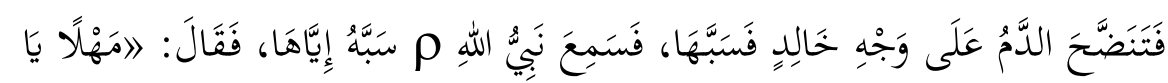

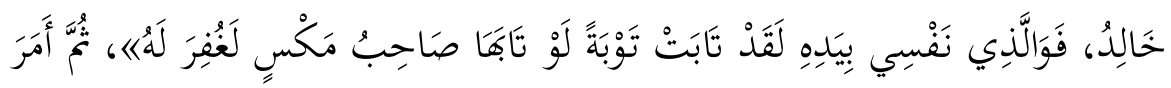

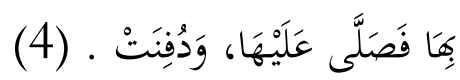

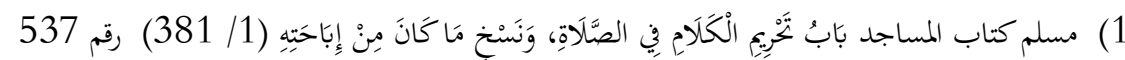

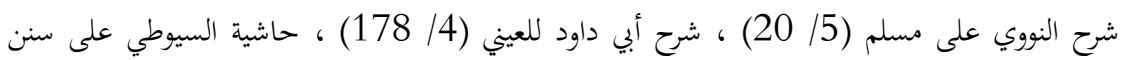

$$
\begin{aligned}
& \text { النسائي (3/ 16) . النولي }
\end{aligned}
$$

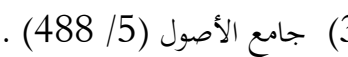

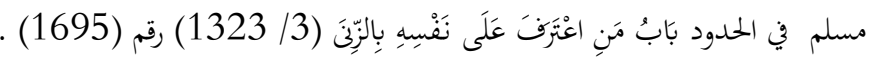




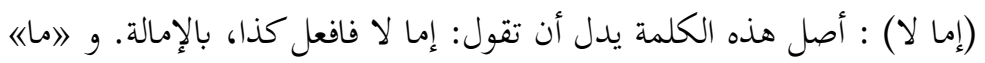

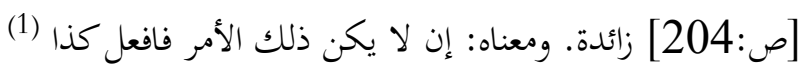

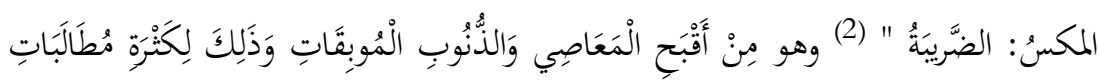

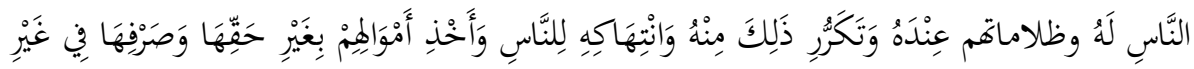

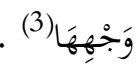

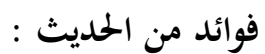

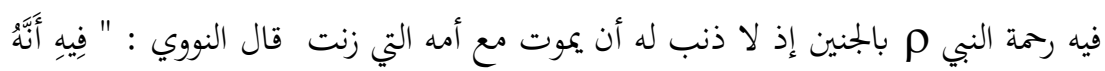

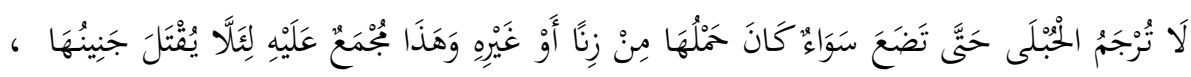

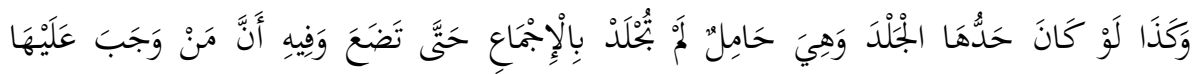

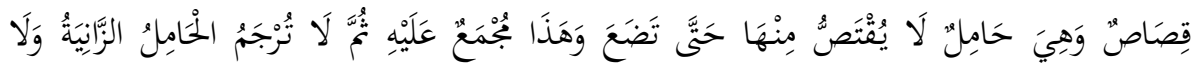

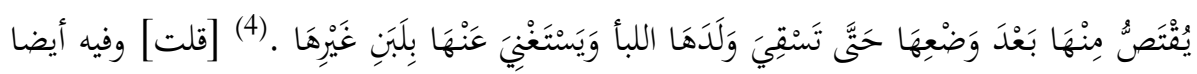

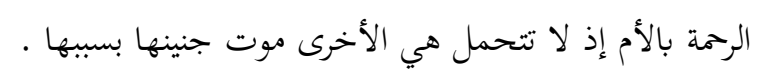

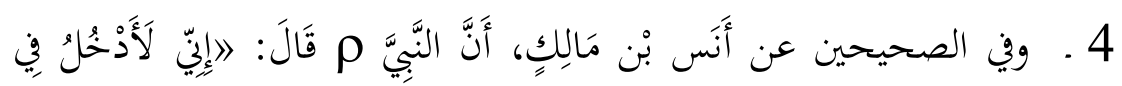

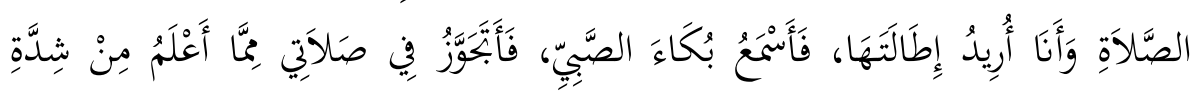

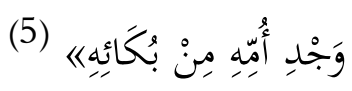

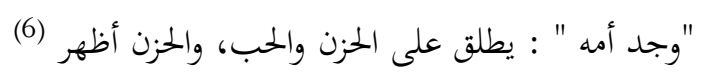
فوائد من الحديث : فيه رمة النبي م بالأم المتلهفة على ولدها الذي يبكي تريد إسكاته فخفف الصلاة من

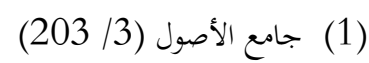

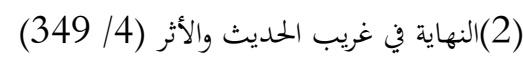

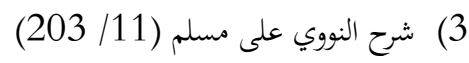

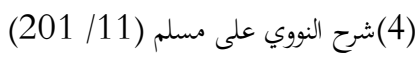

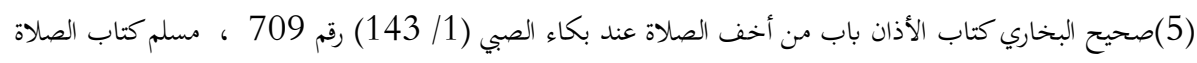

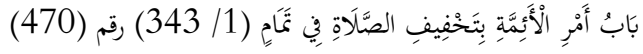

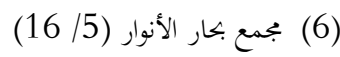


أجلها وولدها .

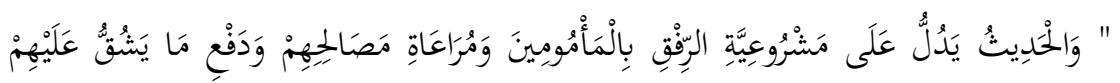

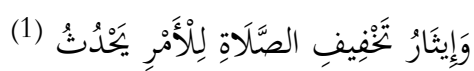

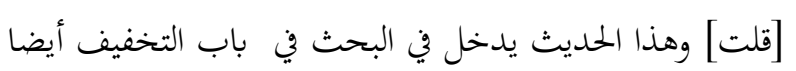

\section{باب(5) في أمر النبي م بالإحسان في التطبيق}

قال الله تعالى : $\}$

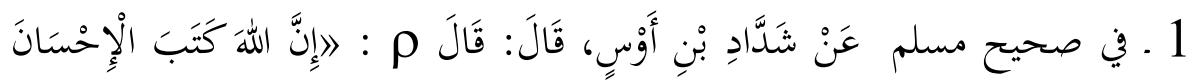

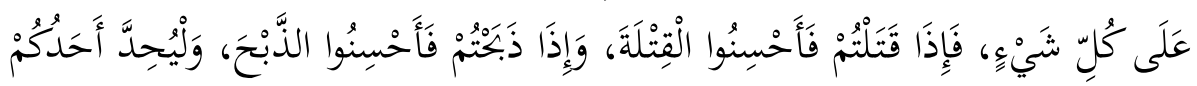

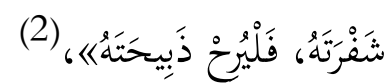
شرح الغريب :

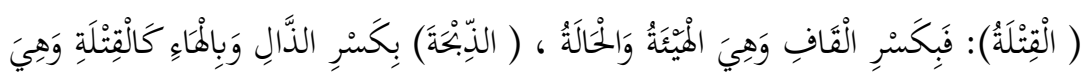

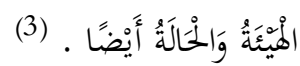

\section{فوائد من الحديث :}

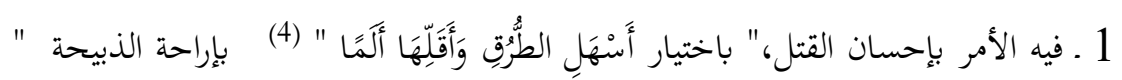

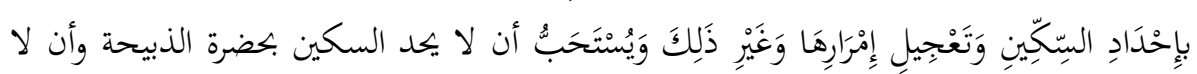

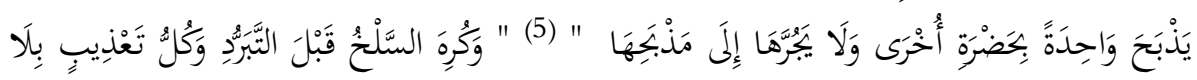

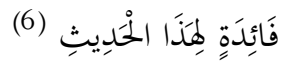

يقول ابن دقيق العيد : " وإحسان الذبح في البهائم: أن يرفق بالبهيمة ولا يصرعها بغتة ولا

(1) عون المعبود (255/2) (1) (25)

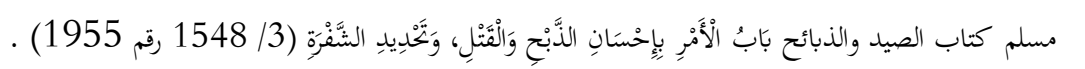

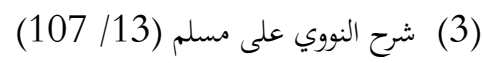

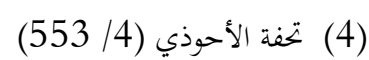

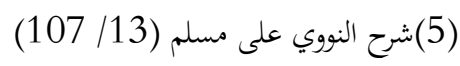

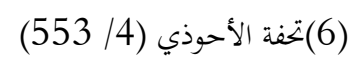

18 


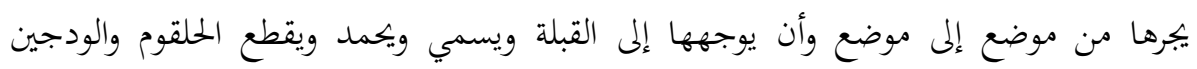

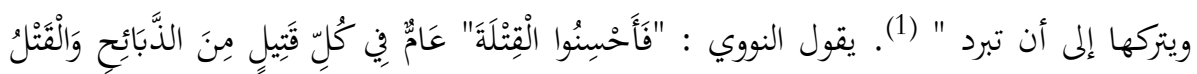

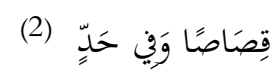

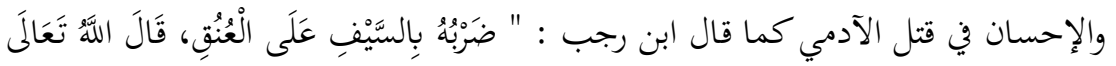

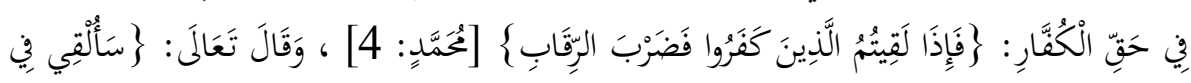

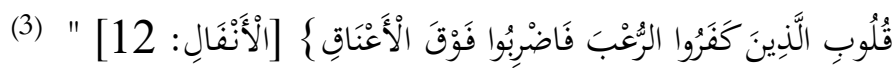

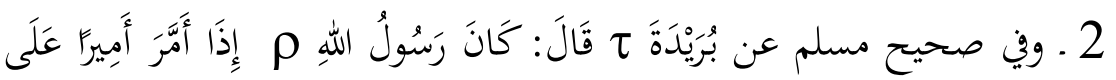

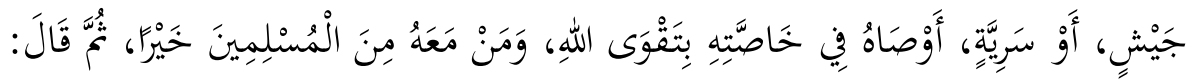

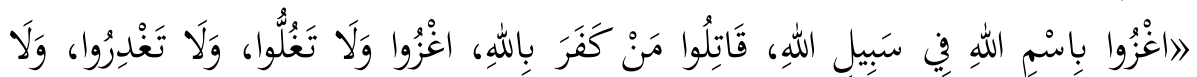

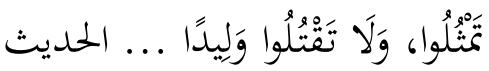

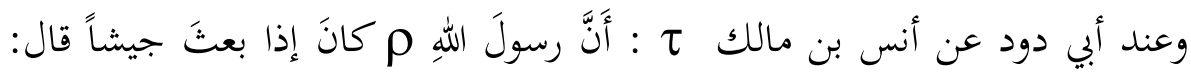

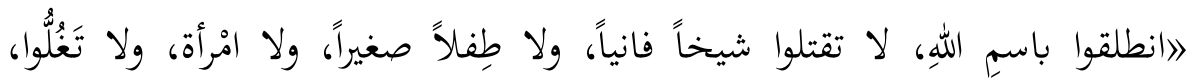

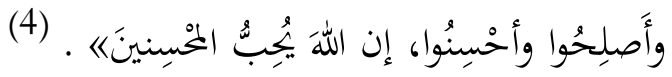

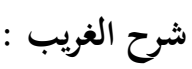
(لا تغلوا) الغل الخيانة، والغُلول: ما يخفيه أحد الغزاة من الغنيمة، ولم يُشضره إلى أمير الجيش ليدخله في القسمة. (لا تمثّلوا) المثلة: تشويه خلقة القتيل، والتنكيل به.

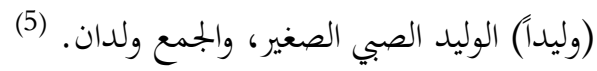

$$
\begin{aligned}
& \text { (1)شرح الأربعين النوية لابن دقيق العيد (ص: 72) }
\end{aligned}
$$

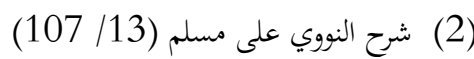

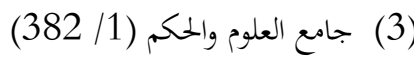

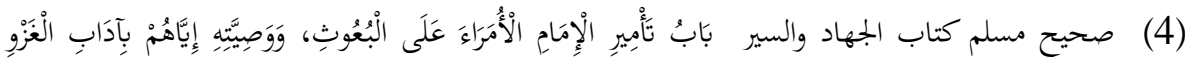

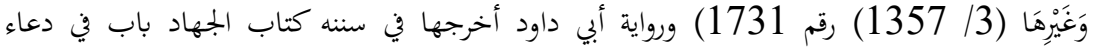

$$
\begin{aligned}
& \text { المشركين (4/4 256) رقم } 2614 \text { ـ } 262 \text {. } \\
& \text { (5) جامع الأصول (2/ 592) . }
\end{aligned}
$$


فيه الإحسان في محاربة العدو فلا غدر ولا تثثيل ولا تعدي ولا قتل لشيخ ووليد وامرأة غير محاربين

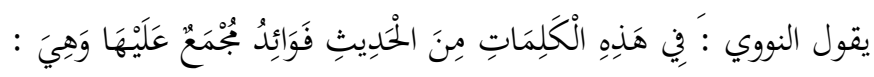

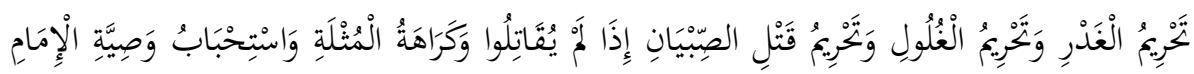

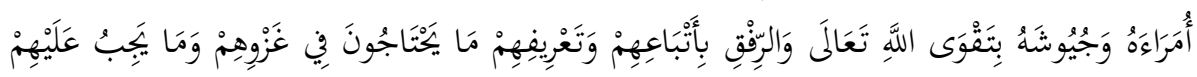

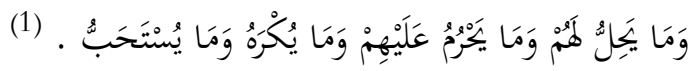

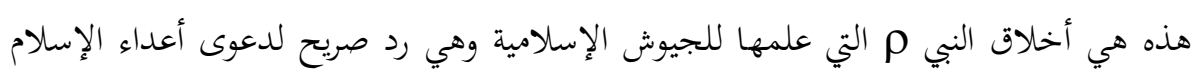

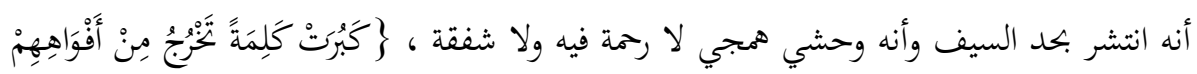

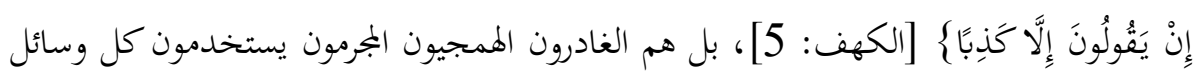

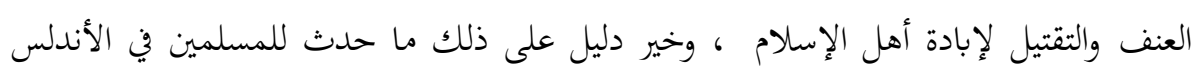

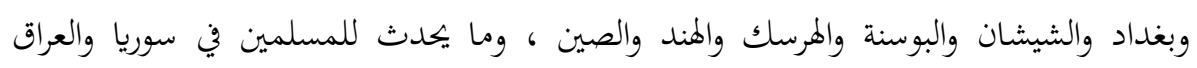

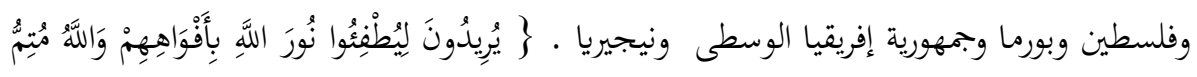

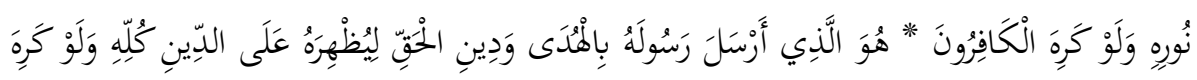

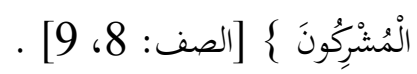

\section{باب (6) في ستر النبي م أهلَ المعاصي وعدم فضحِهم}

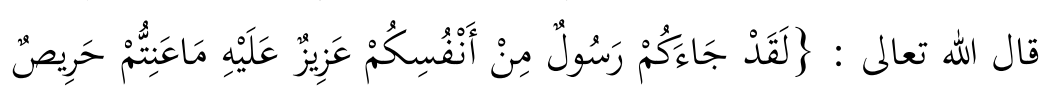

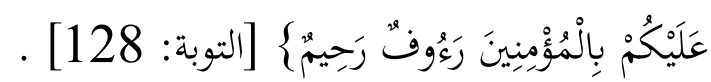

1

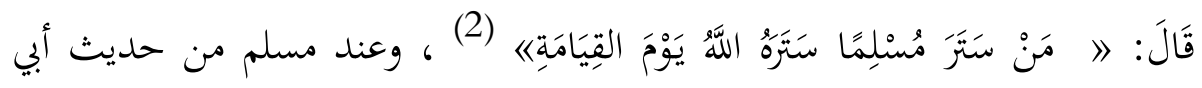

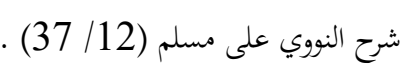

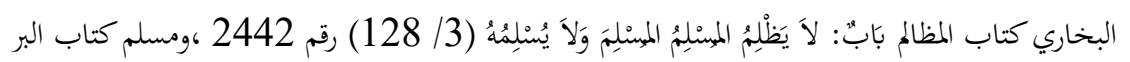

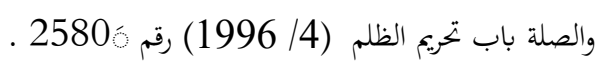




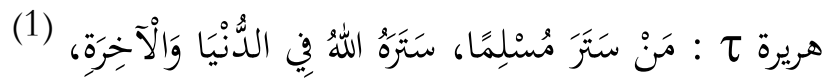

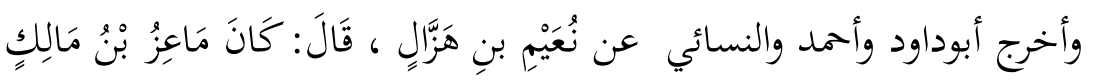

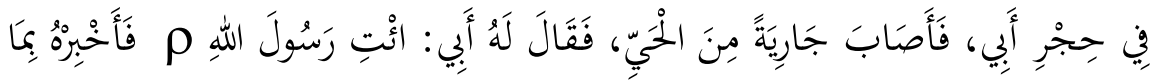

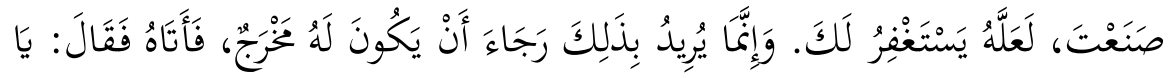

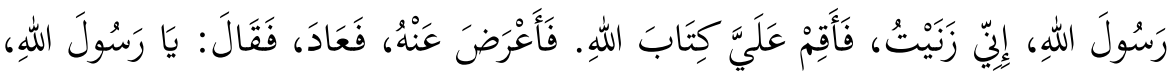

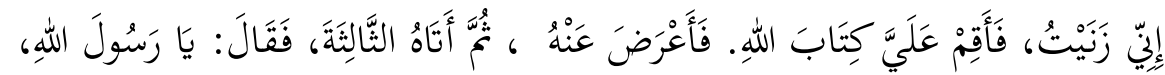

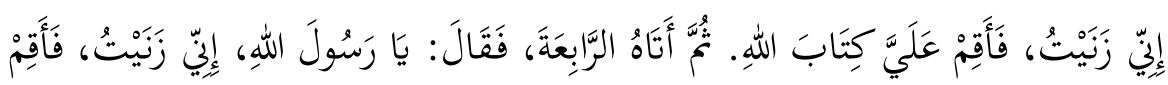

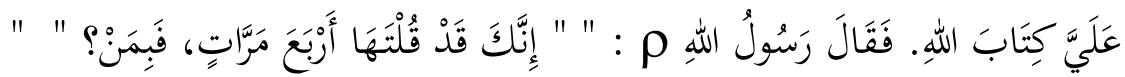

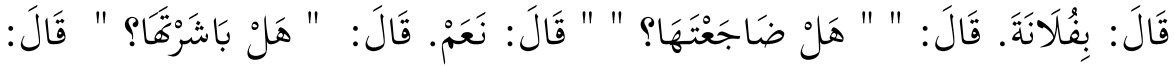

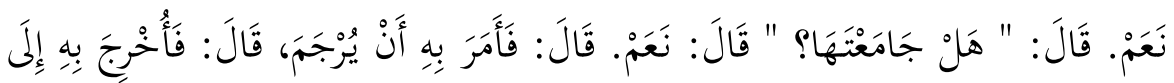

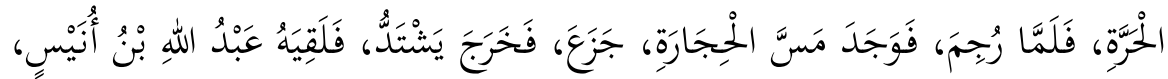

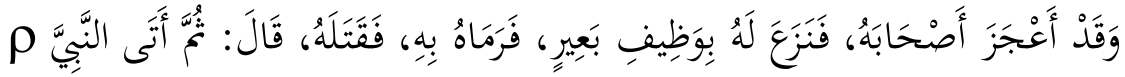

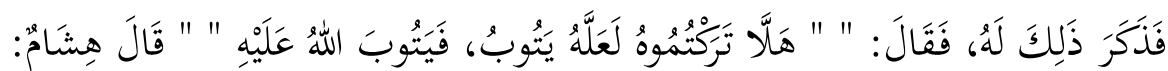

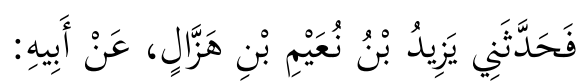

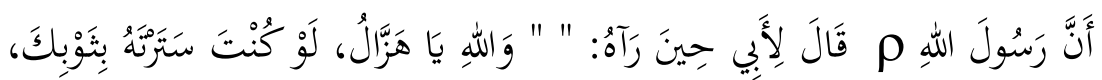

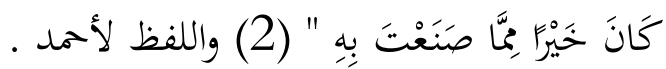

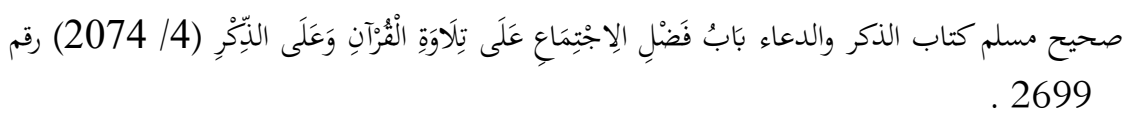

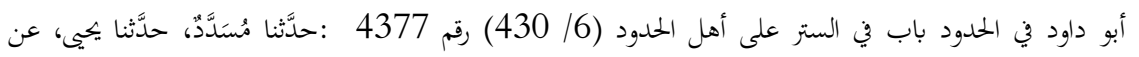

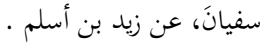

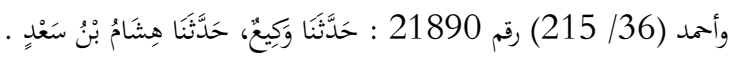

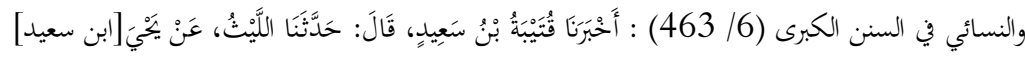

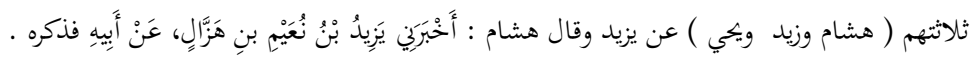

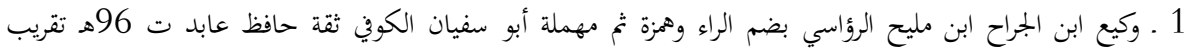
التهذيب (ص: 581 5رقم 7414 ) . 
وأصل الحديث في الصحيحين عن ابن عباس رضي الله عنهما وفيه : الََلَّلَكَ

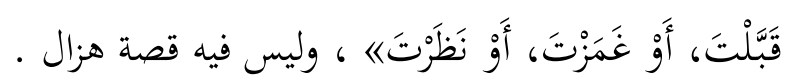

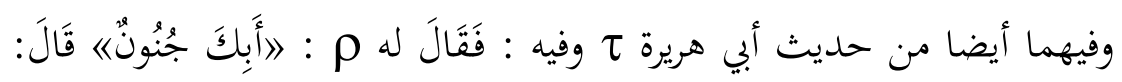

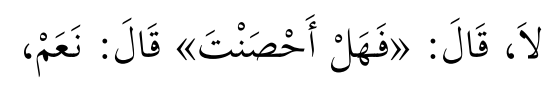

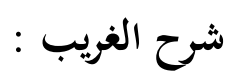

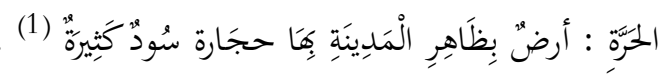

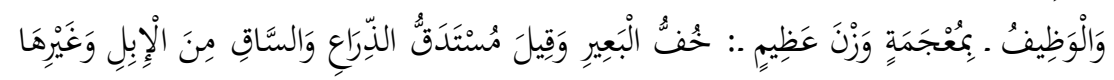

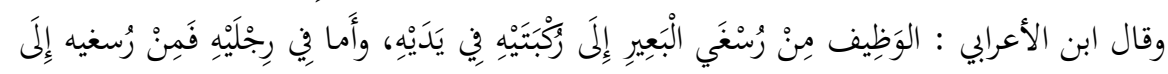
عُرقوبيه (2)

\section{فوائد من الحمديث :}

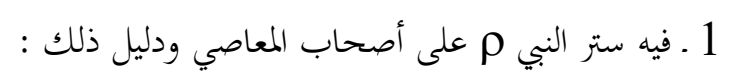

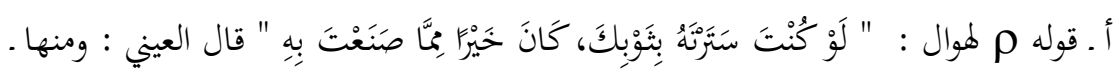

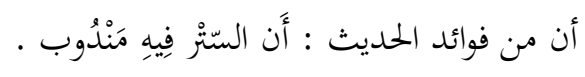

ب ـ وأيضا في إعراض النبي م عن ماعز أربع مرات ، ليرجع ماعز ويتوب ويستر على فئل

2 ـ هشام ابن سعد المدني أبو عباد أو أبو سعيد صدوق له أوهام . تقريب التهذيب ت 160هـ (ص: 572 رقم 7294

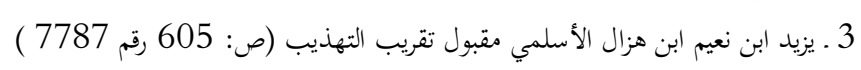

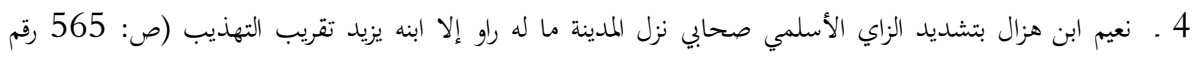
( 7176

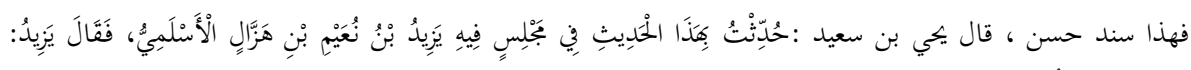

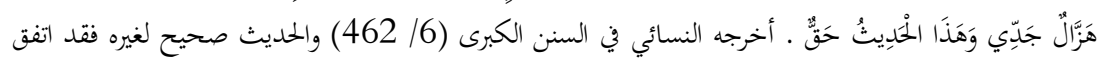

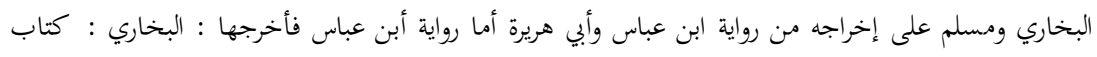

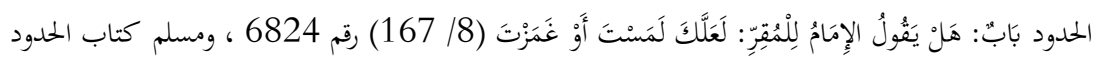

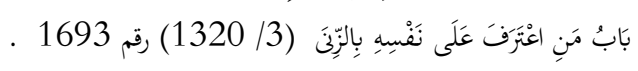

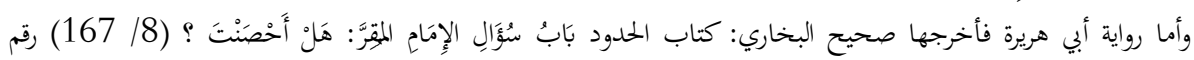

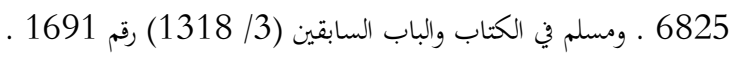

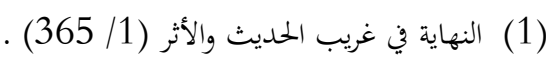

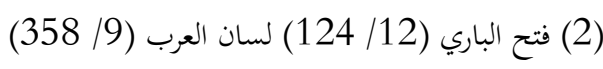


وهذا دليل على أن توبة الإنسان بينه وبين الله خير من اعترافه بالمعصية ، والمسألة فيها

$$
\text { خلاف بين العلماء . - ماك. }
$$

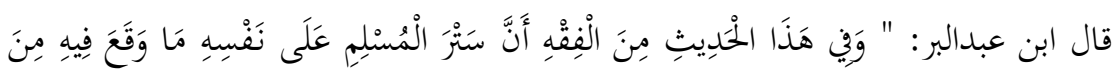

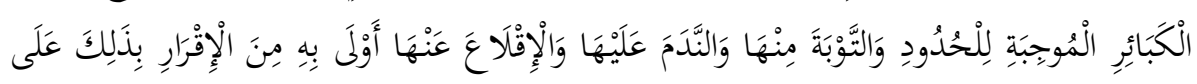

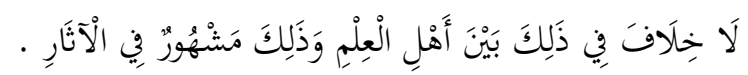

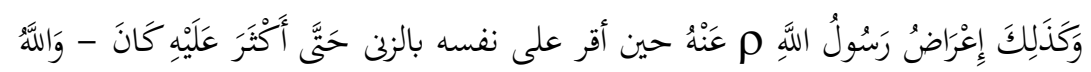

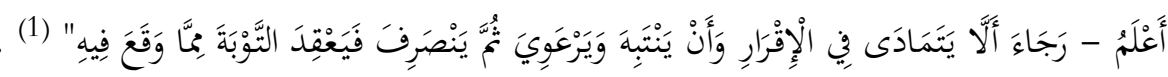

$$
\text { باب(7) درء النبي م الحدود ما استطاع }
$$

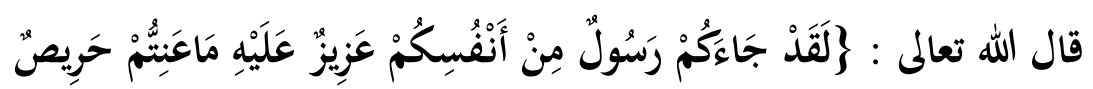

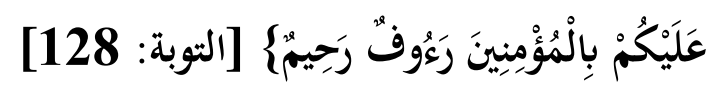

$$
\begin{aligned}
& 1 \text { ـ ـ حديث الصحيحين السابق عن ابن عباس في قصة ماعز وقول النبي م : }
\end{aligned}
$$

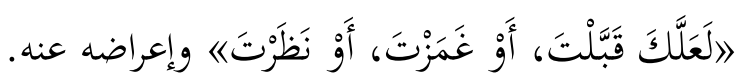

2 ـ حديث الصحيحين السابق عن أبي هريرة ح وقول النبي م لماعز : اأَبِكَ

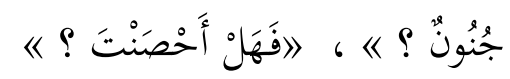

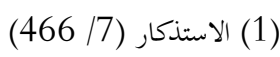


3 ـ وأخرج أبوداود والنسائي عن عبدِ الله بنِ عمرو بنِ العاص، أن رسولَ الله م

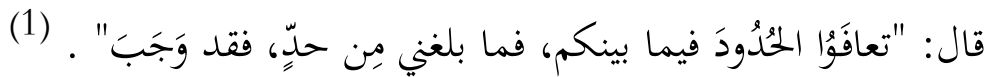

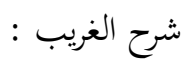

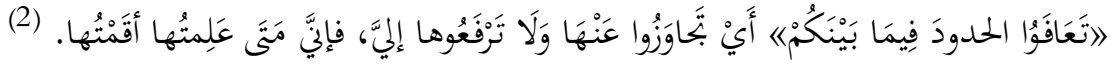

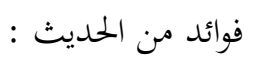

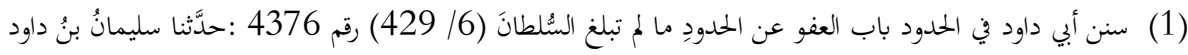

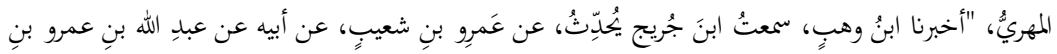

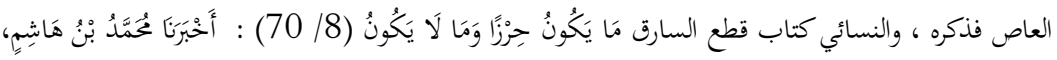

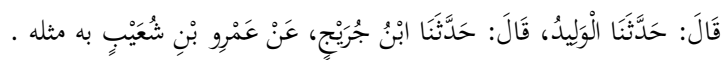

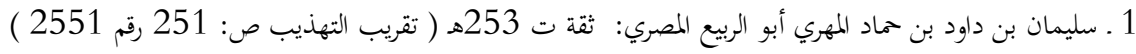

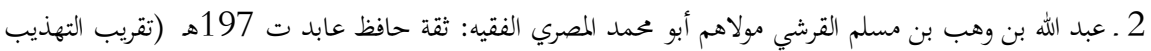

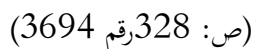

3 3 ابن جريج : عبد الملك بن عبد العزيز بن جريج الأموي مولاهم المكي: ثقة فقيه فاضل وكان يدلس ويرسل ت 150 150ه.

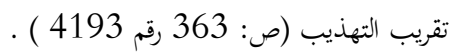

4. عمرو بن شعيب بن حمد بن عبد الله بن عمرو ابن العاص صدوق ت 118 هـ تقريب التهذيب (ص: 423 رقم . 5050

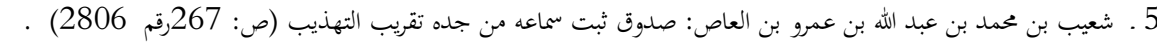

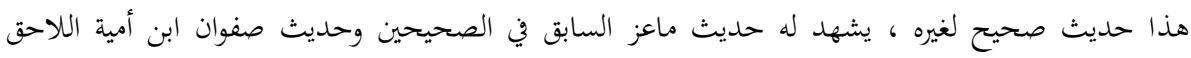

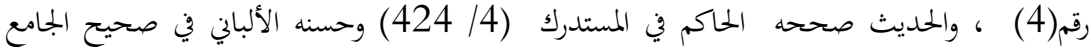

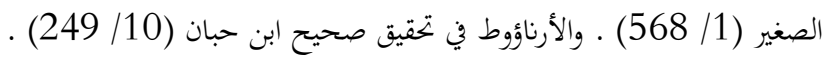

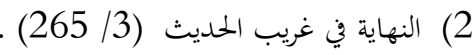




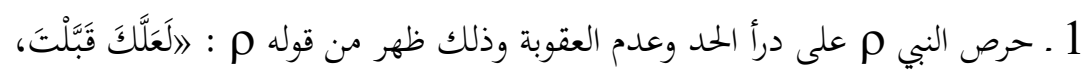

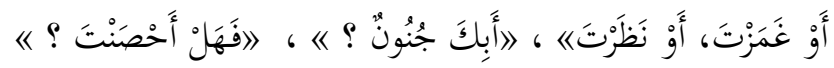

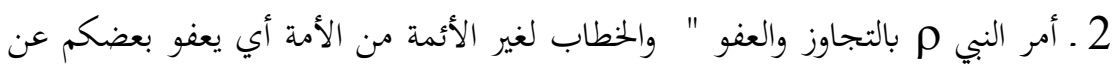

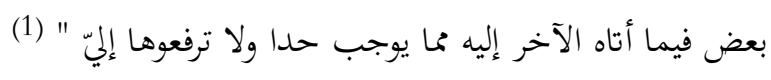

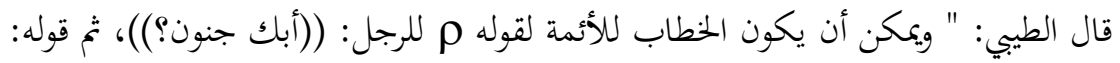

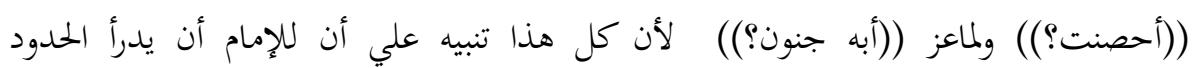
بالشبهات (2) (2) (1)

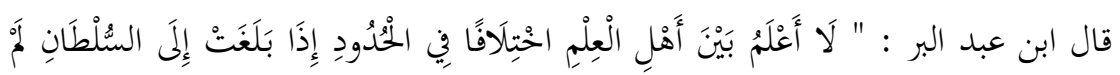

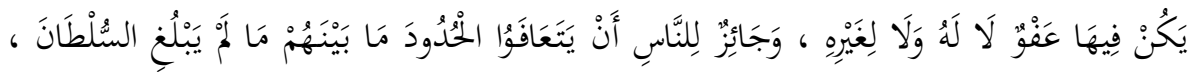

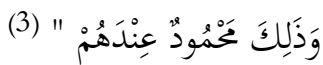

\section{باب(8) في قبول البي م رجوع المقر بالحد عن إقراره ، وأنه لا يُحُُّ}

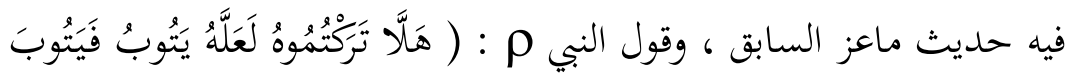

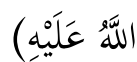

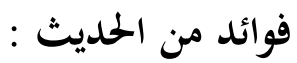

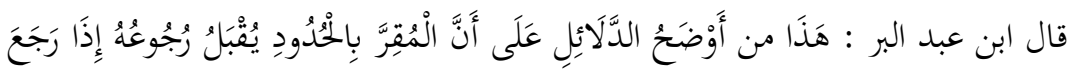

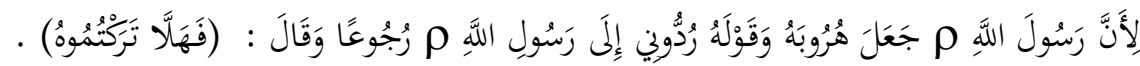

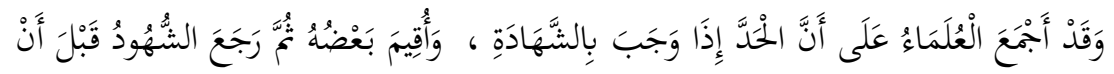

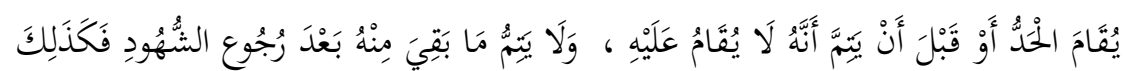

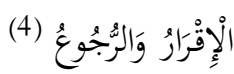

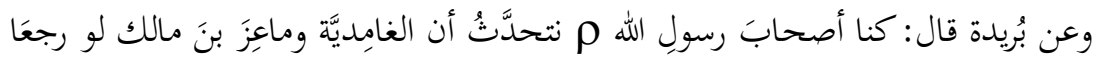

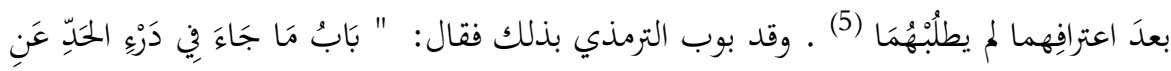

$$
\text { (1) التنوير شرح الجامع الصغير (5/ 51) (15) }
$$

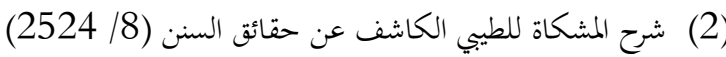

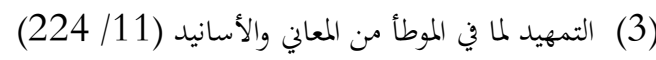

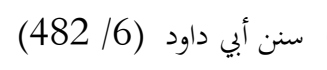




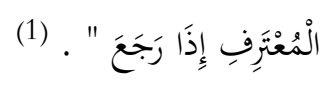

باب(9) بيان أن القائم بتطبيق الحدود هو الإمام أو نائبه ولا يترك لآحاد الناس منعا للفوضى

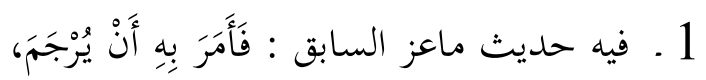

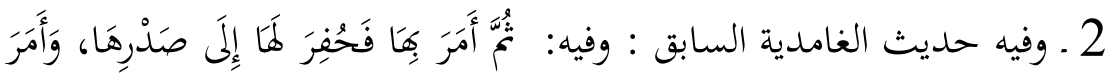

النَّاسَ فَرَجَمَوهَا

فوائد من الحديث : فركون

فيه أن الذي يتولى إقامة الحدود هو الإمام أو نائبه منعا للفوضى ، إذ لو تُرك الأمر للناس ،

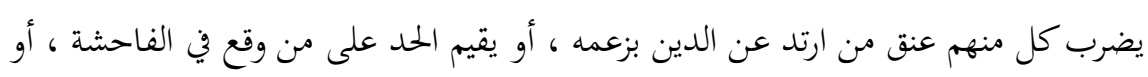

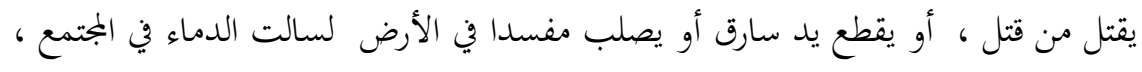

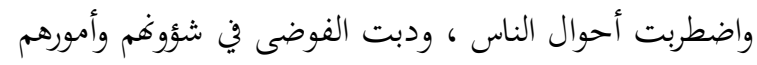

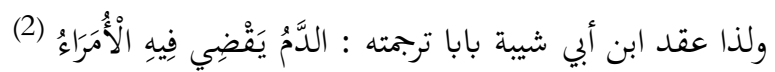

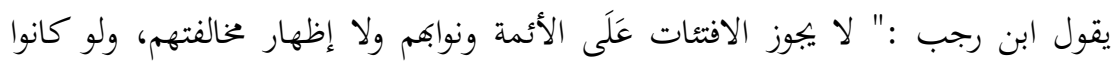

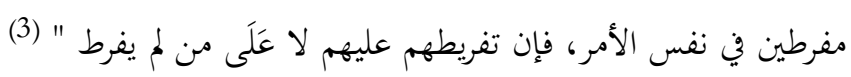

\section{باب (10) في مساواة النبي م بين الناس في تطبيق الشريعة وعدم قبول شفاعة في تعطيل شريعة}

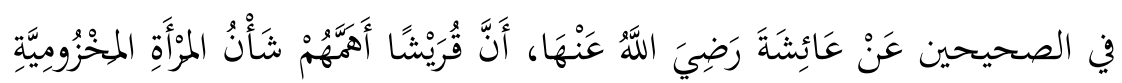

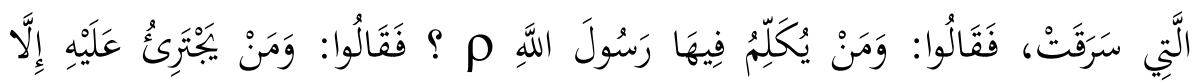

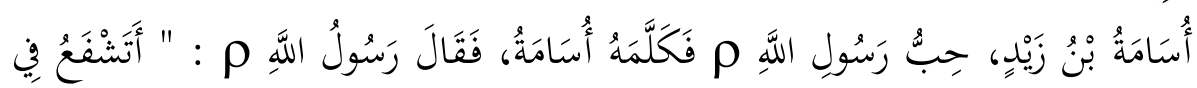

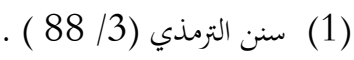

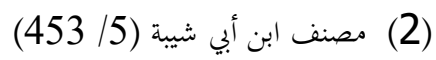

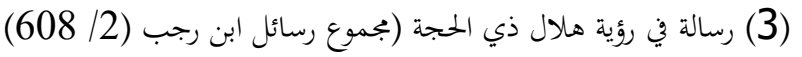




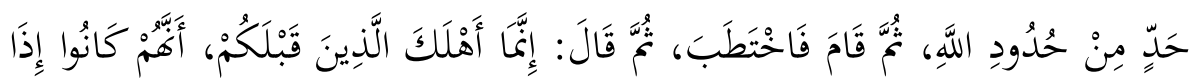

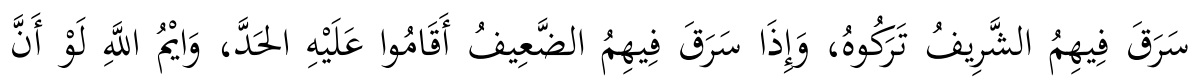

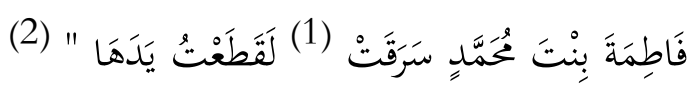

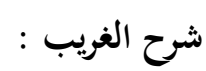

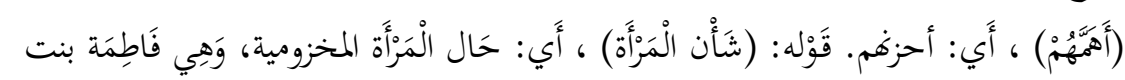

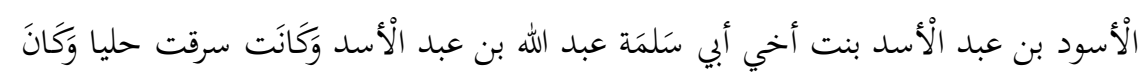
ذَلِكَ فِي غَزْوَة الْفَتْح.

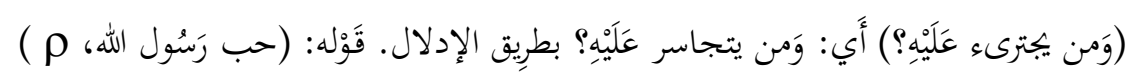

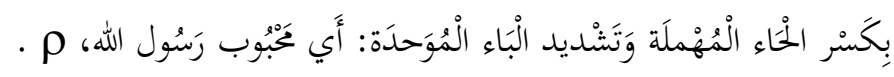

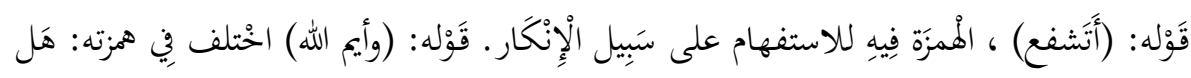

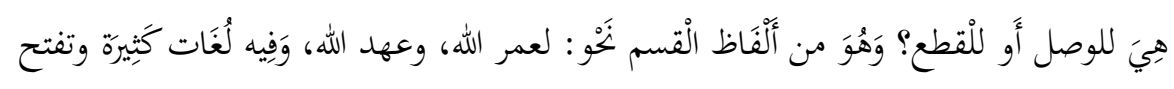

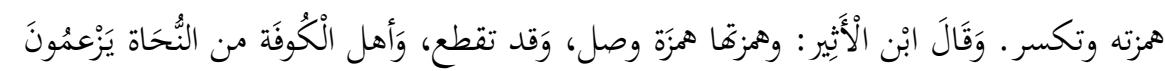

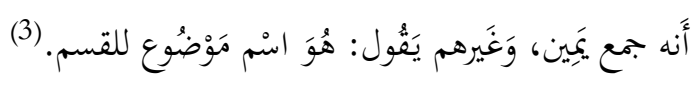
فوائد من المحديث :

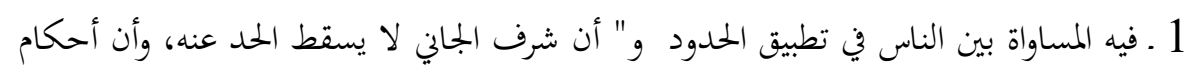

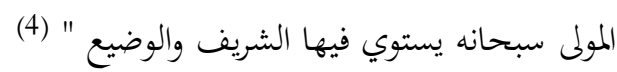
2 وفيه عدم قبول الشفاعة لإسقاط الحد ما دام وصل إلى الإمام .

\section{باب(11) في مراعاة النبي م الأولويات في التطبيق}

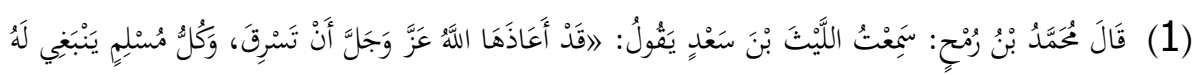

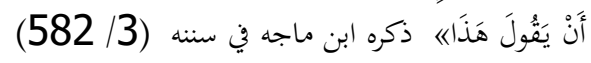

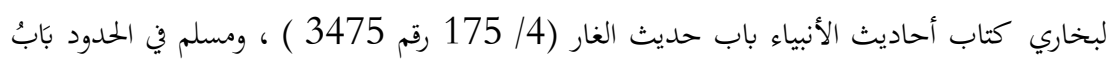

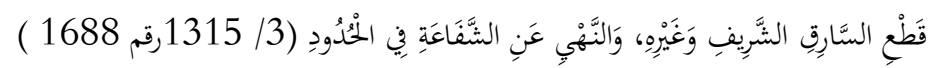

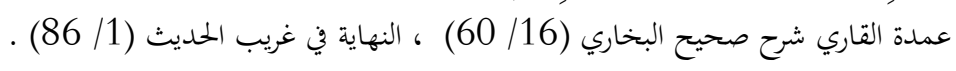

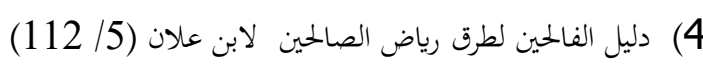




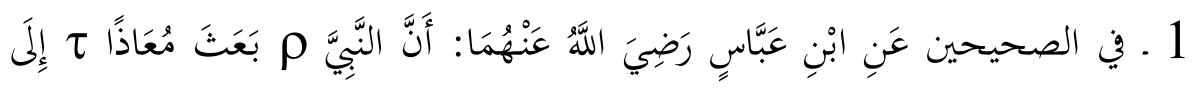

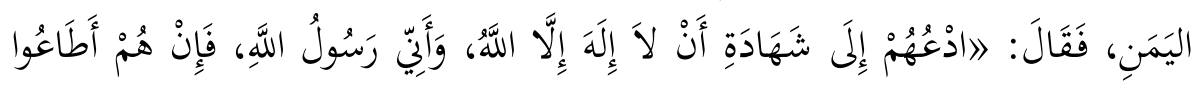

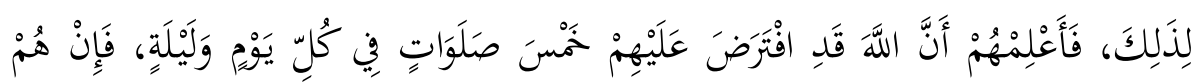

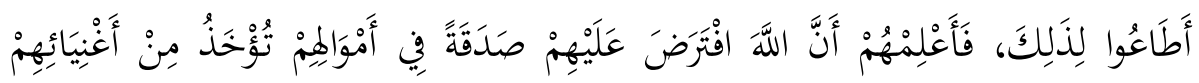

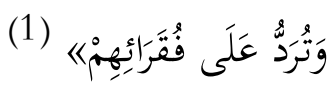

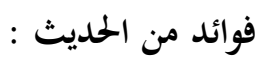

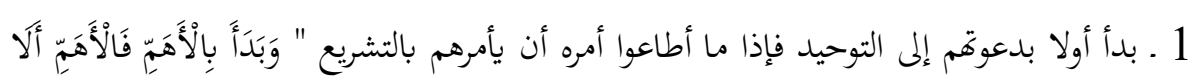

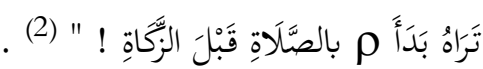

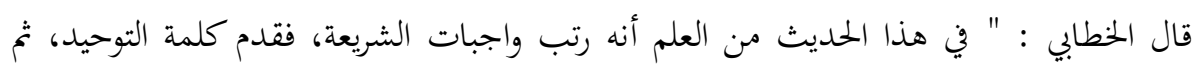

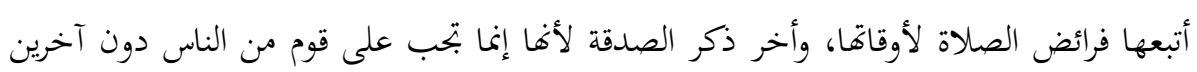

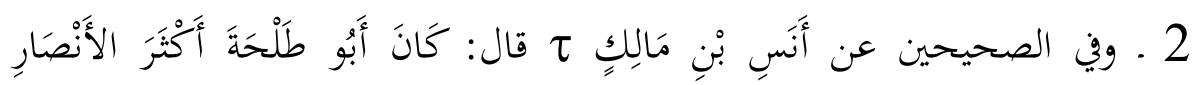

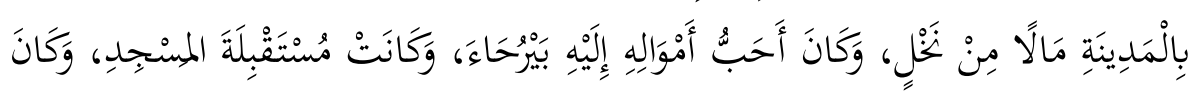

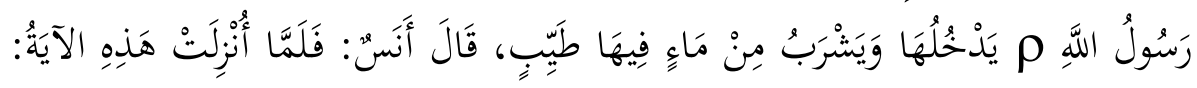

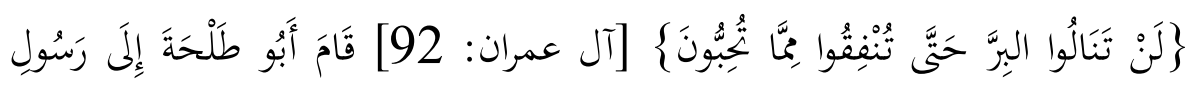

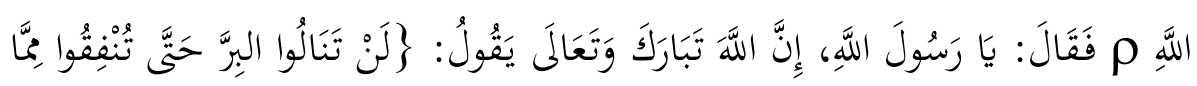

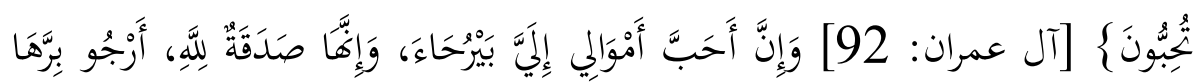

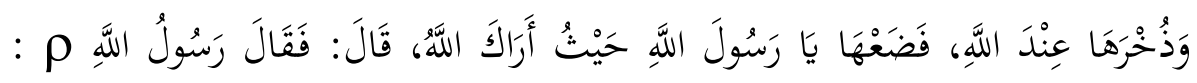

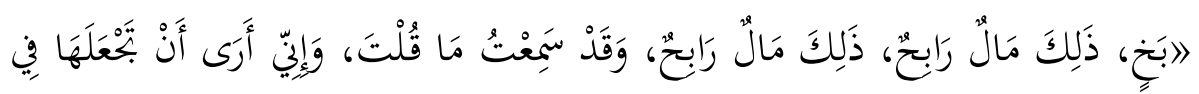

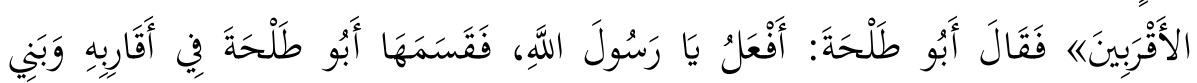

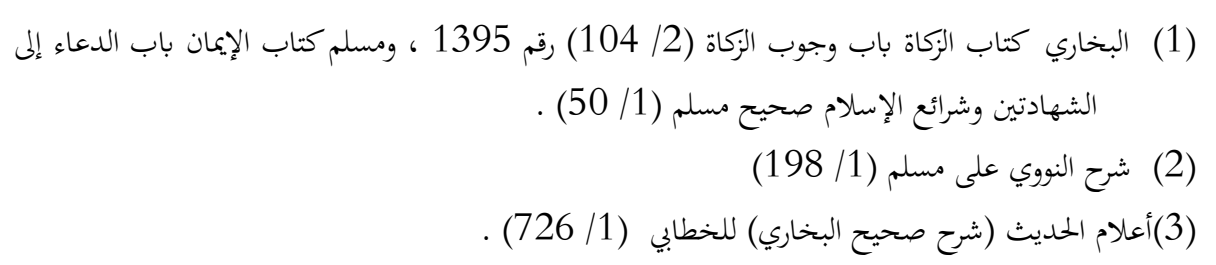




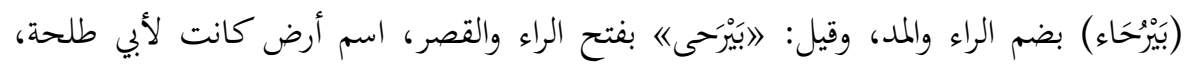

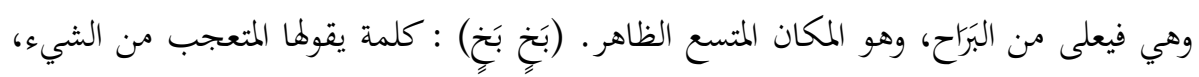

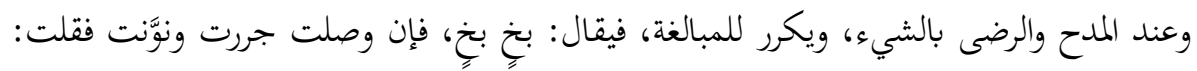

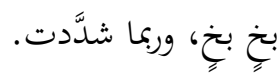
(مال رابح، ورايح) رابح بنقطة واحدة، معناه: ذو رِبْح، وأما بنقطتين، فمعناه: أنه قريب المسافة يروح خيره ولا يغرب.

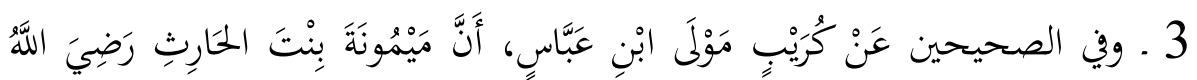

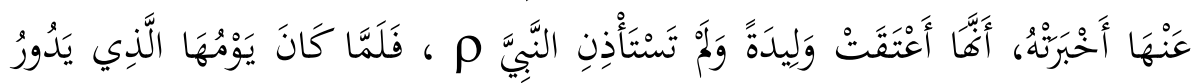

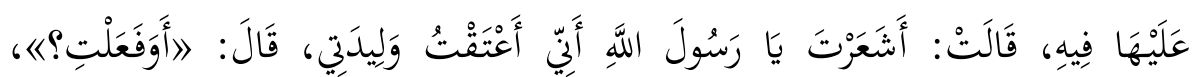

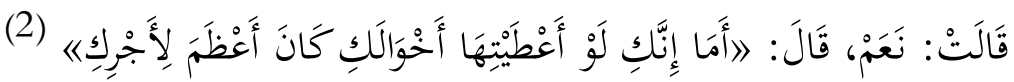
شرح الغريب

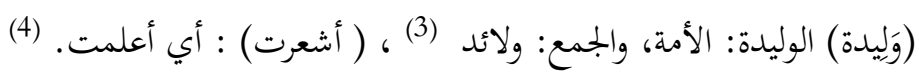

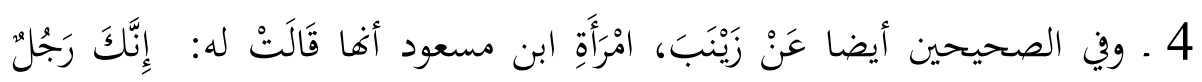

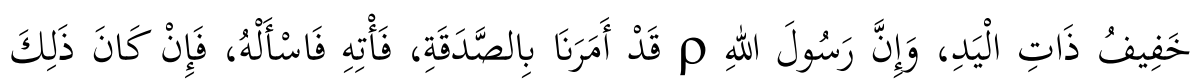

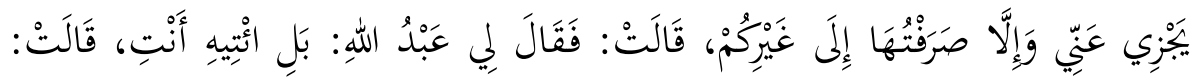

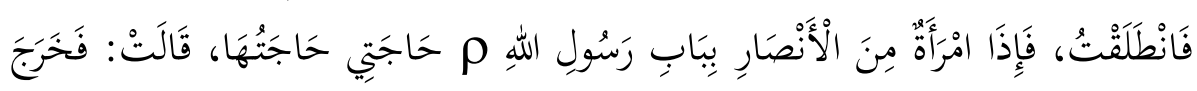

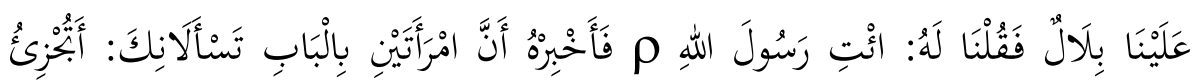

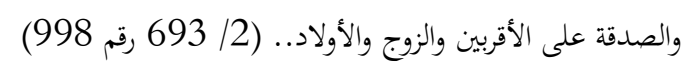

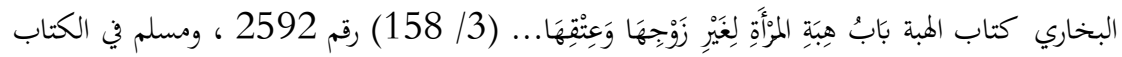

$$
\begin{aligned}
& \text { والباب السابقين (2/ 694) . }
\end{aligned}
$$

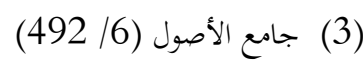

$$
\begin{aligned}
& \text { لسان العرب (4) (409) الاصول (402/4) . }
\end{aligned}
$$




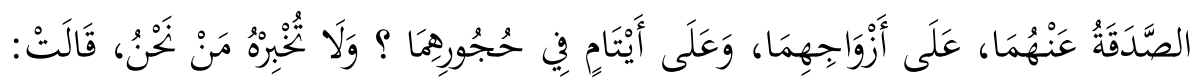

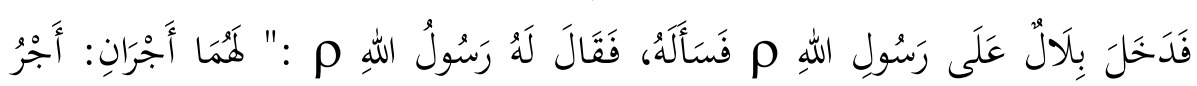

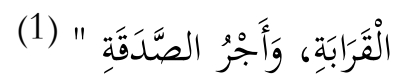

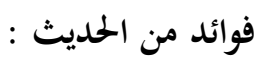

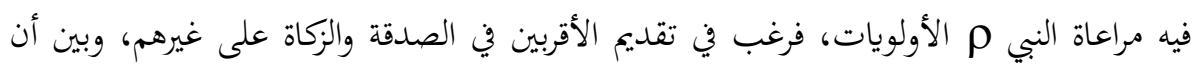

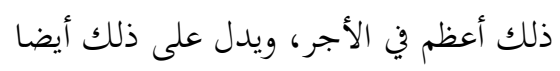

\section{باب (12) في إقامة النبي م الحجة والإعلام قبل التطبيق}

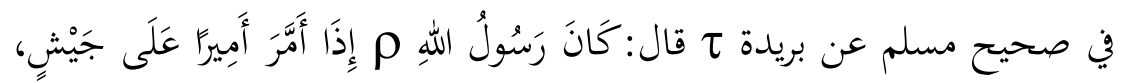

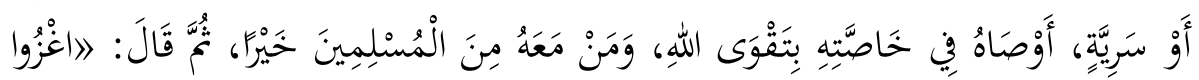

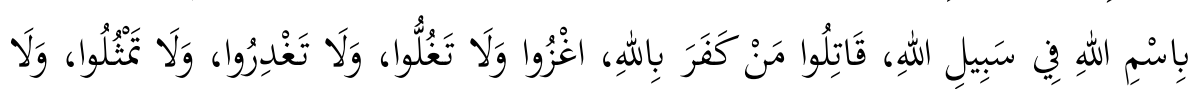

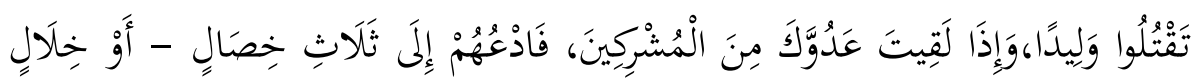

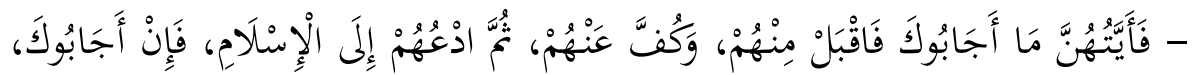

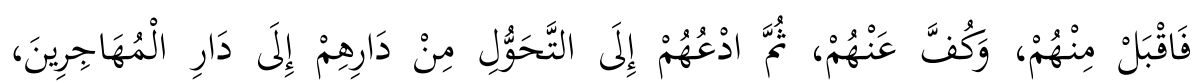

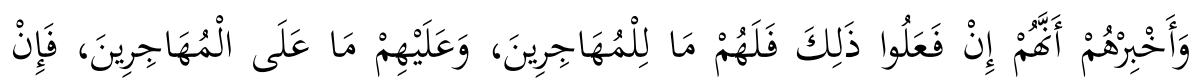

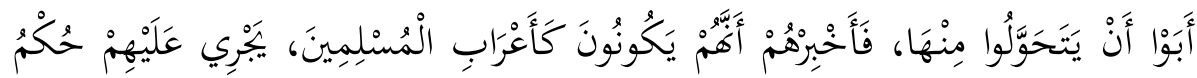

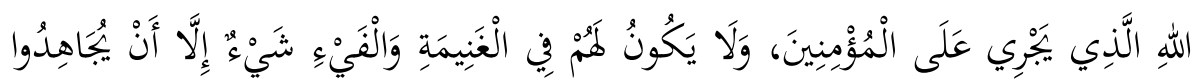

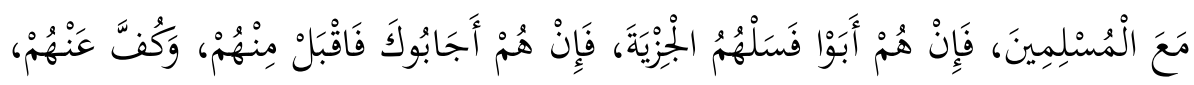

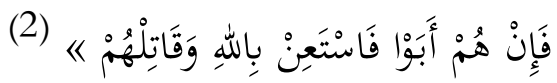

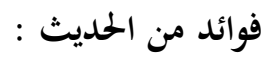

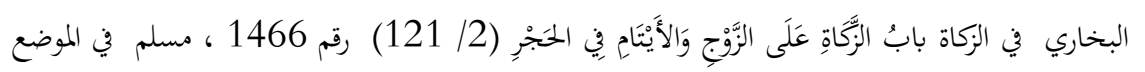

$$
\begin{aligned}
& \text { السابق (2/ 694) رقم (1000) . } \\
& \text { (2) تقدم تخريهه في باب الإحسان }
\end{aligned}
$$




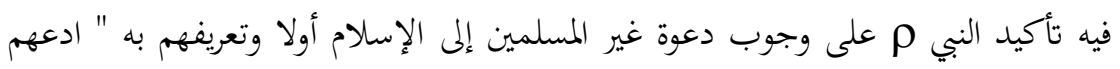

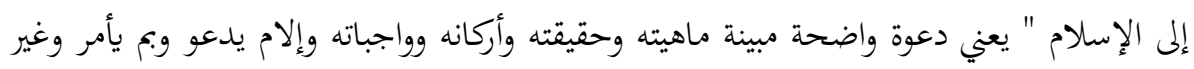

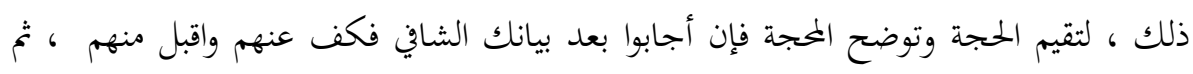

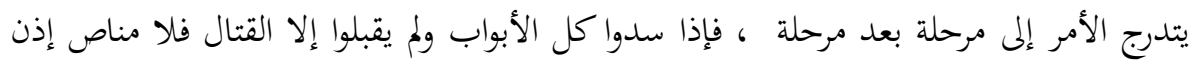

\section{باب (13) في امتثال النبي م الشرع قبل الناس}

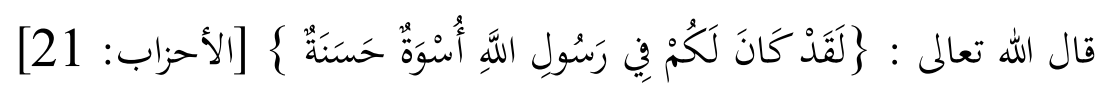

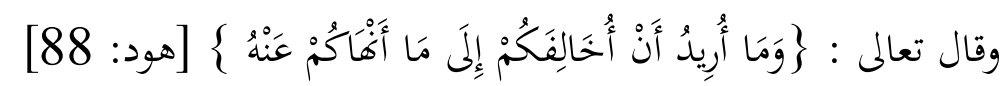

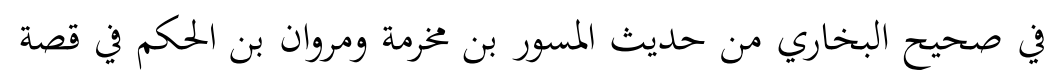

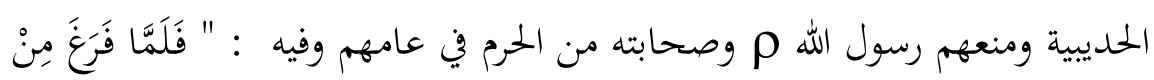

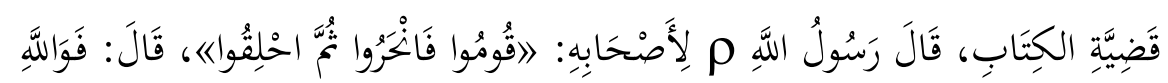

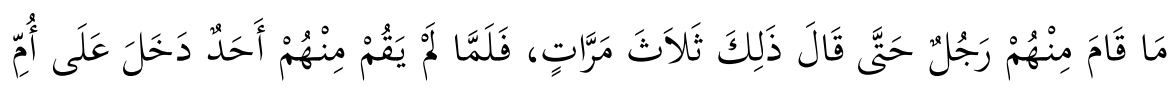

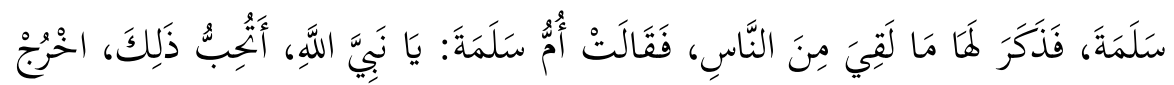

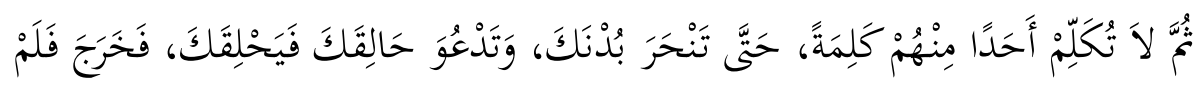

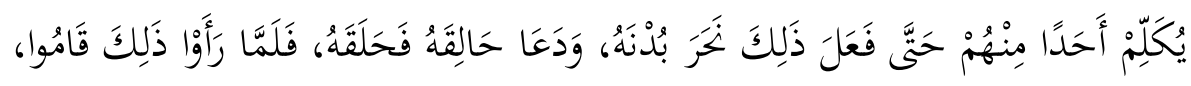

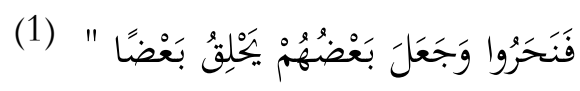
فوائد من الحديث :

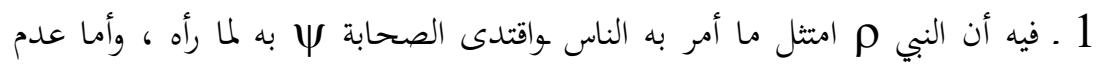

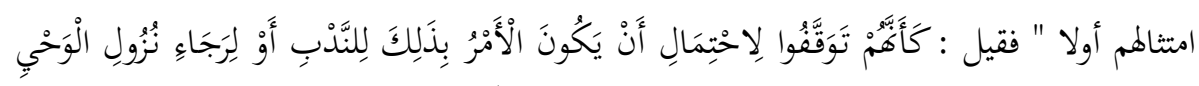

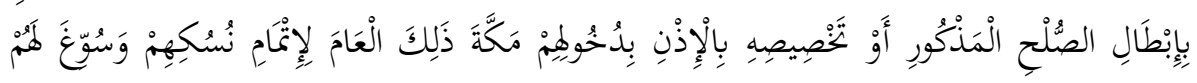

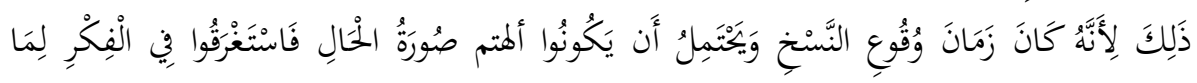

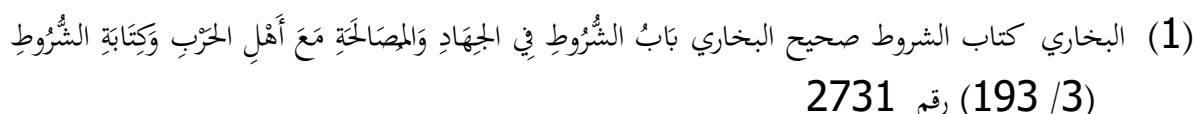




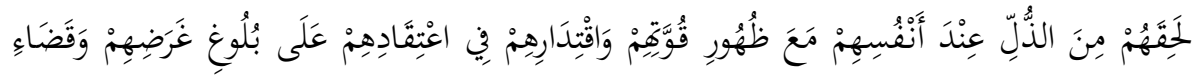

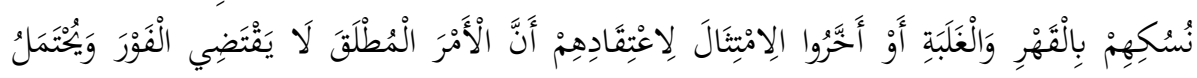

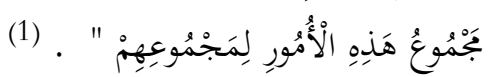

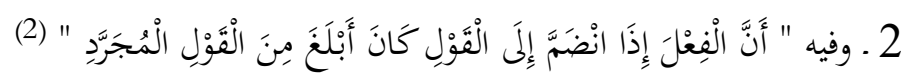

\section{باب(14) في مراعاة النبي م جلب المصالح ودفع المفاسد والنظر في المآلات}

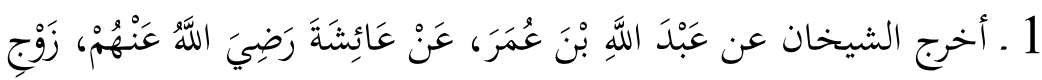

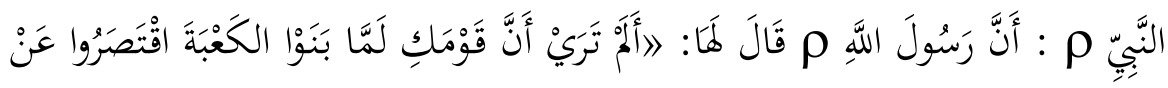

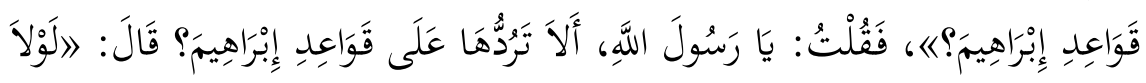

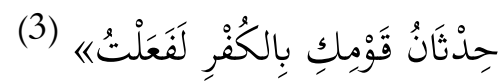

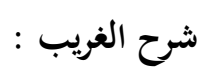

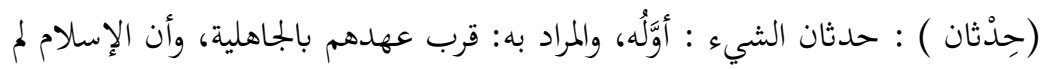

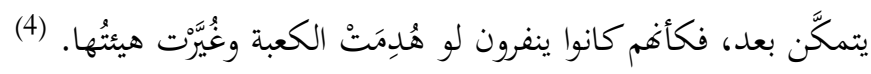

$$
\text { فوائد من الحديث : }
$$

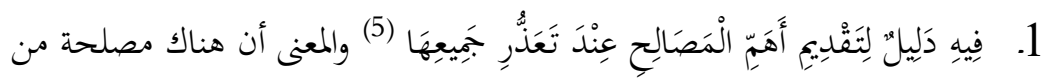

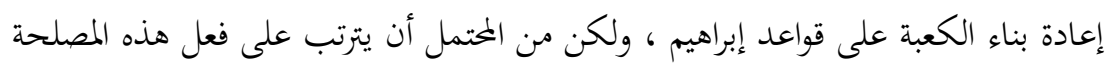

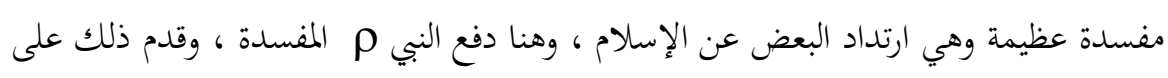

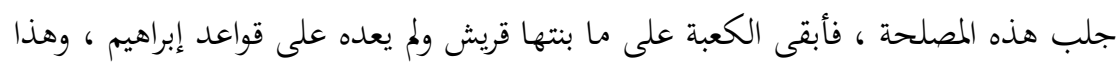

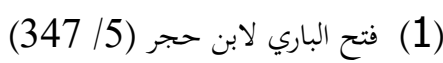

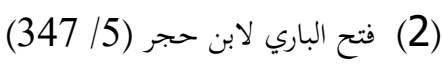

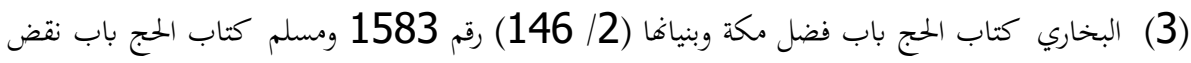

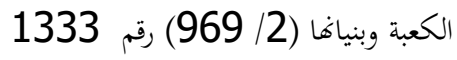

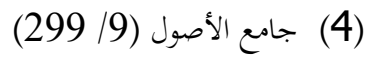

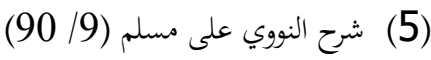




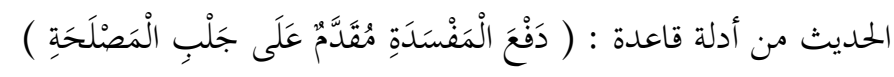

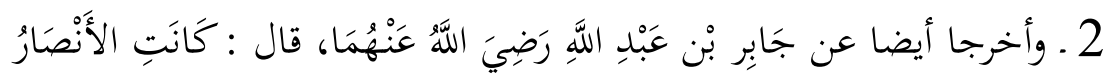

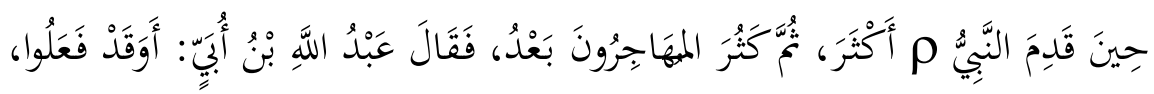

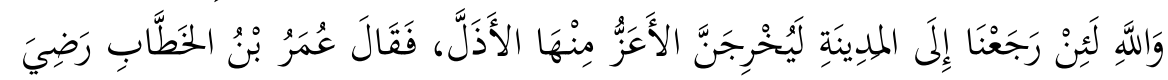

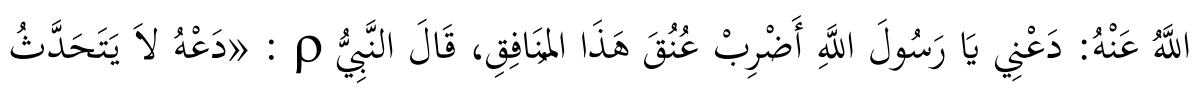

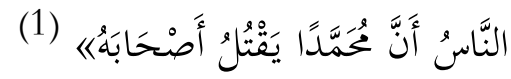

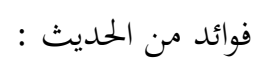

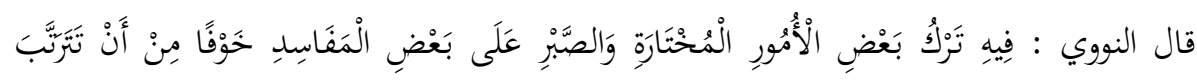

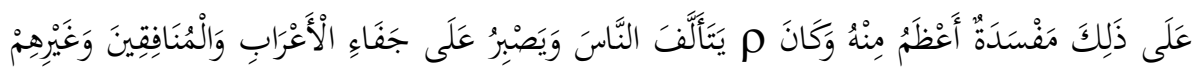

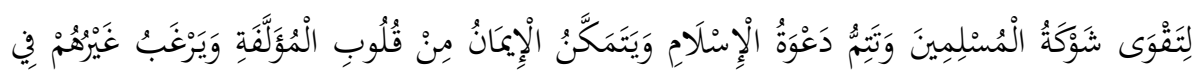

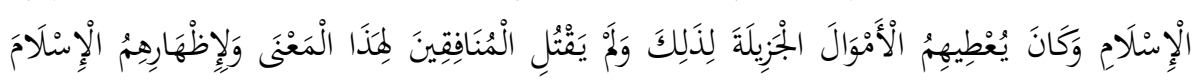

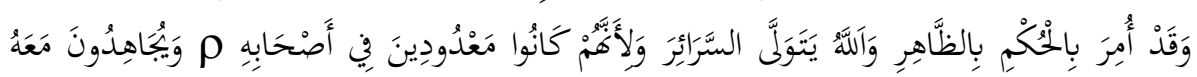

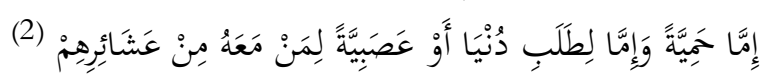

باب(15) في أمره م بإجراء الأحكام على الظاهر، وعدم الحكم على الى

$$
\text { السرائر }
$$

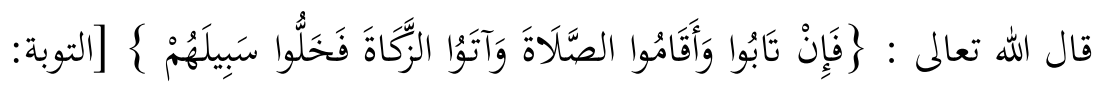

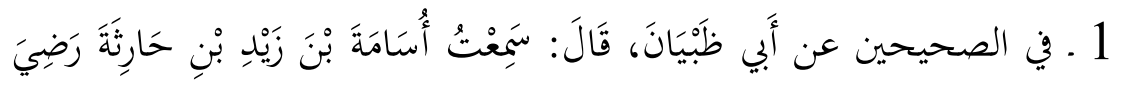

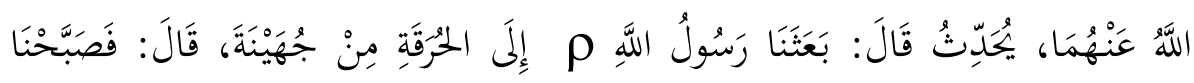

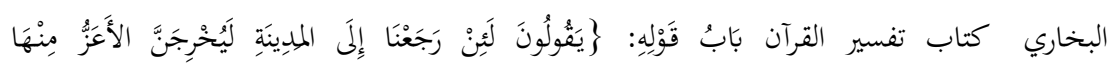

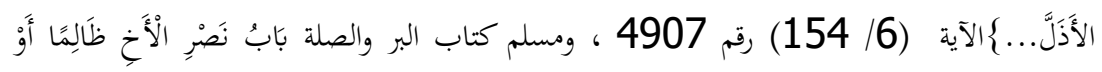
مَظُْومًا (4/ 1998) رقم 2584 (2) شرح النووي على مسلم (14 / 138) 


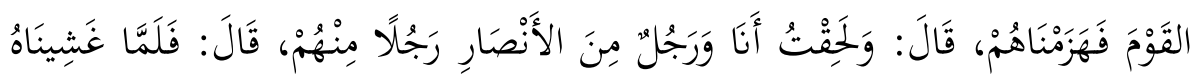

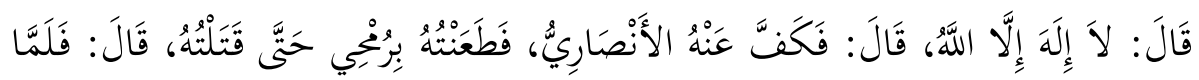

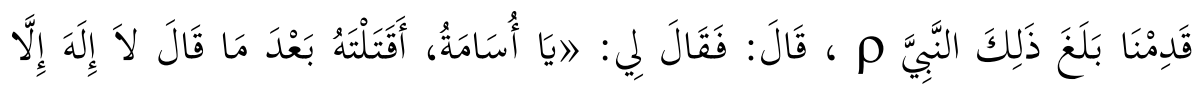

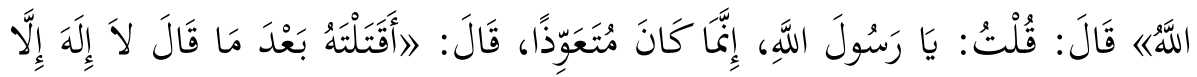

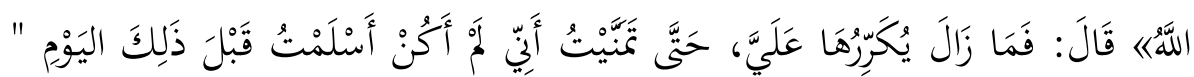

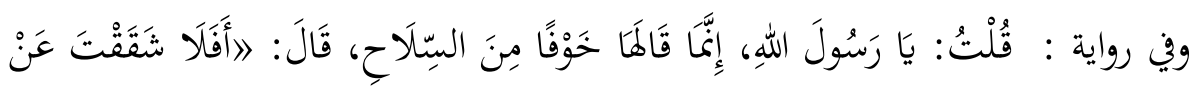

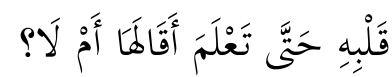

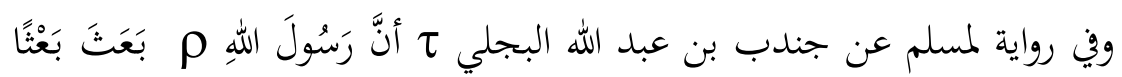

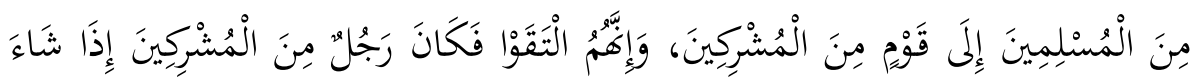

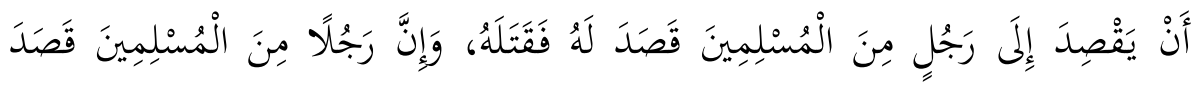

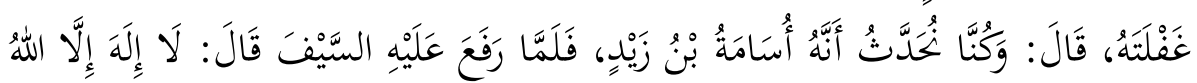

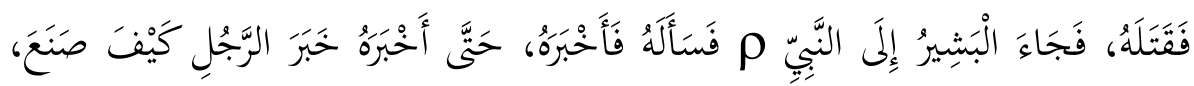

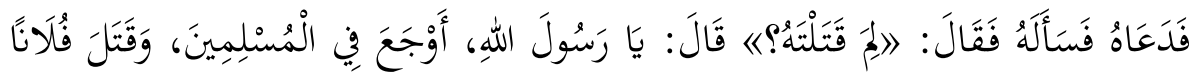

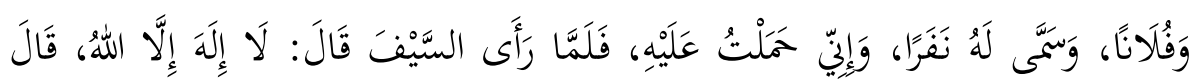

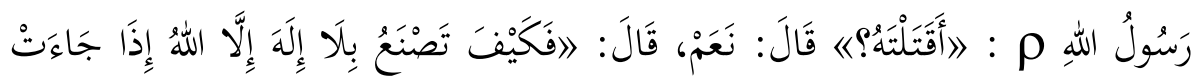

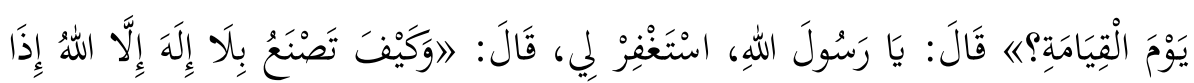

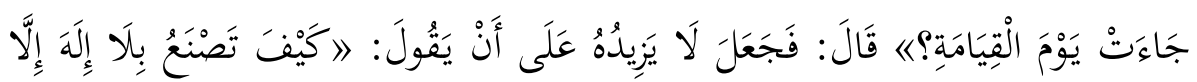

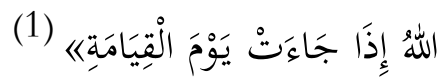

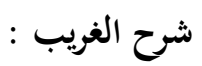
الححُرَّة: بضم الحاء، وفتح الراء، والقاف: هو ابن عامر بن مودعة بن جُجَهَيْنَة أبو قبيلة من

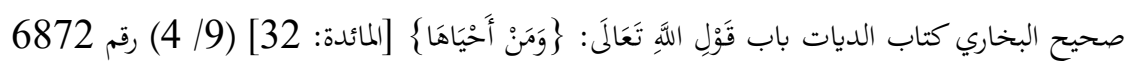

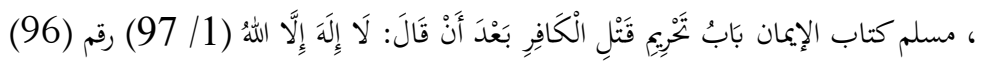




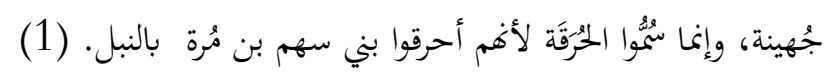
(غَشَيناه) أدركناه ولحقناه، كأفم أَتَوهُ من فَوقهه.

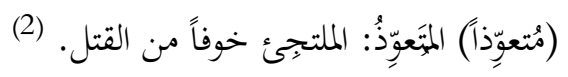

$$
\text { فوائد من الحمديث : }
$$

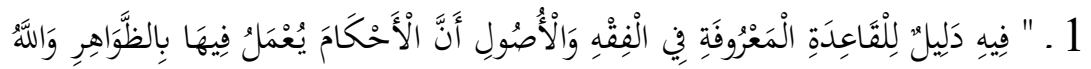

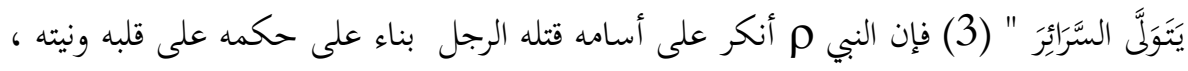
وقال له :

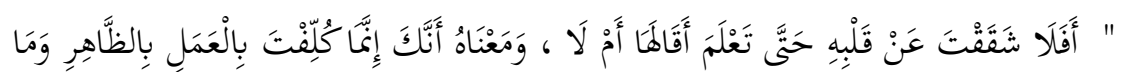

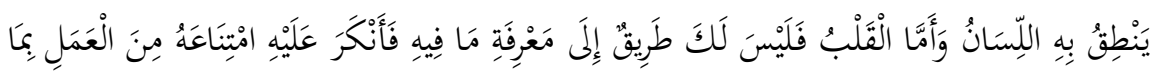

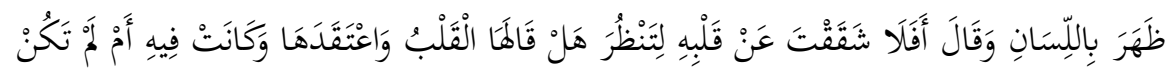

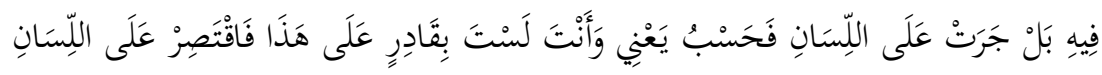

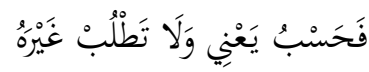

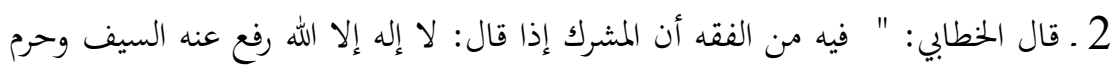

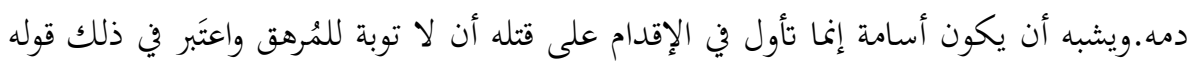

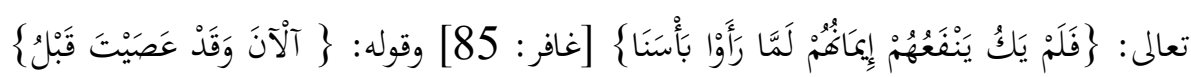

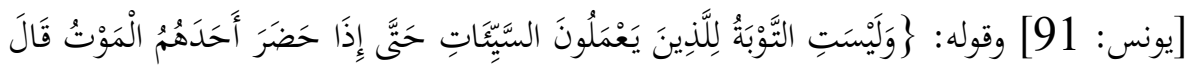

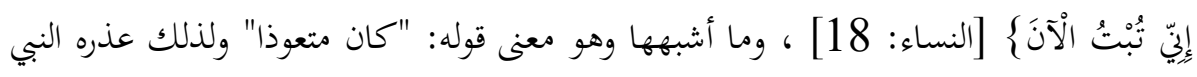

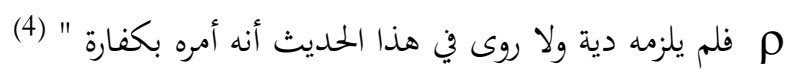

باب (16)مراعاة البي م سوابق الحخير للإنسان وقبول عذره إن أخطأ ،

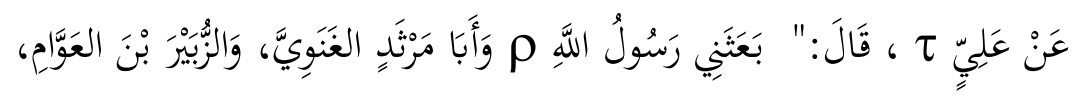

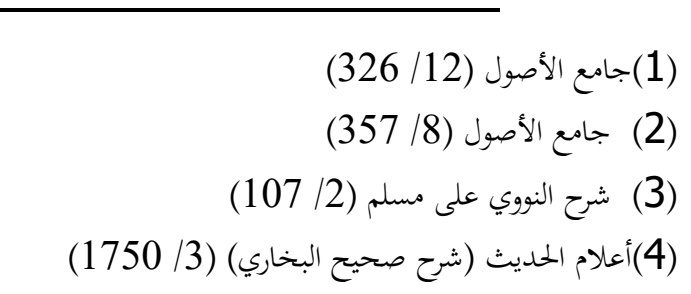




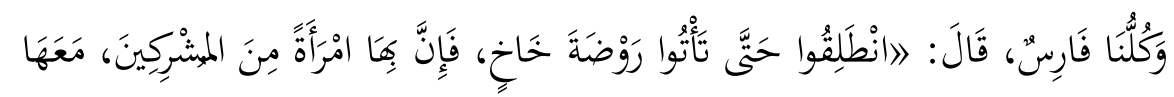

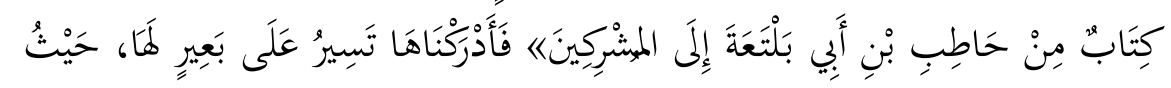

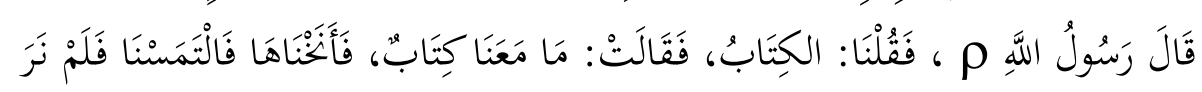

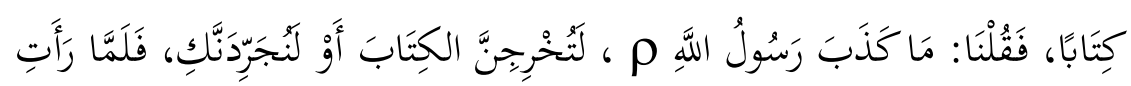

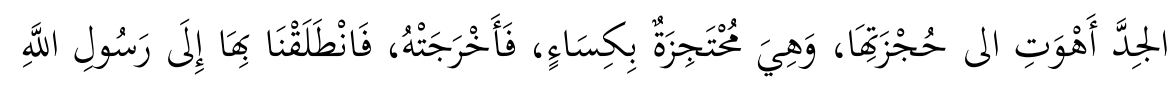

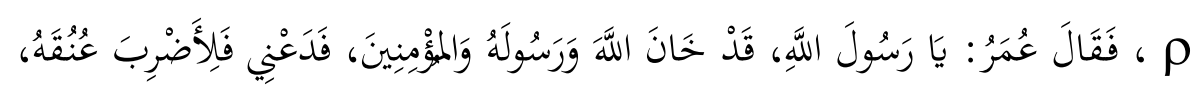

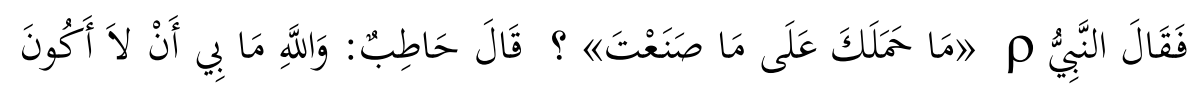

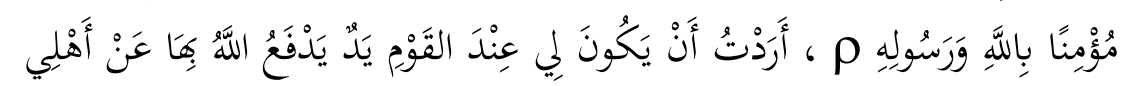

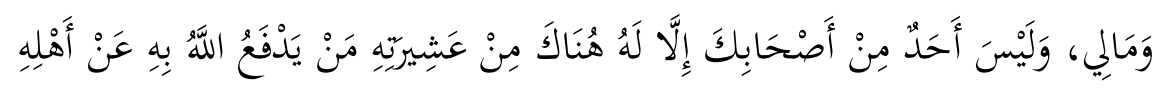

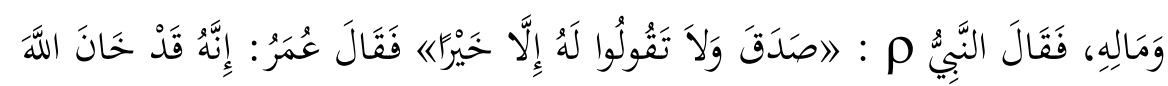

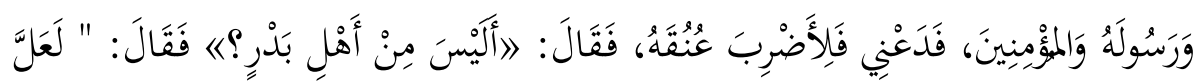

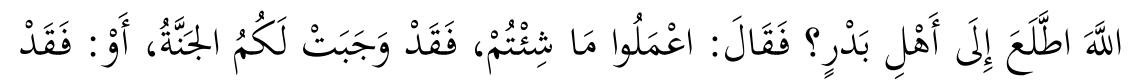

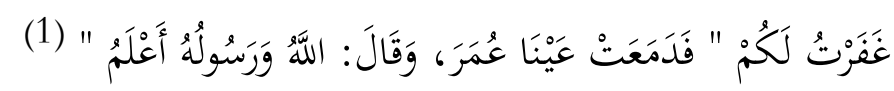

$$
\text { فوائد من الحديث }
$$

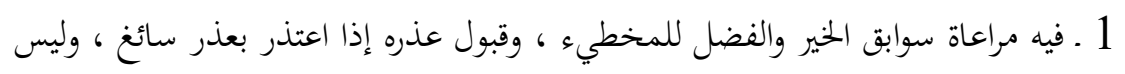

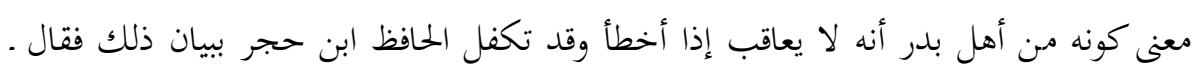

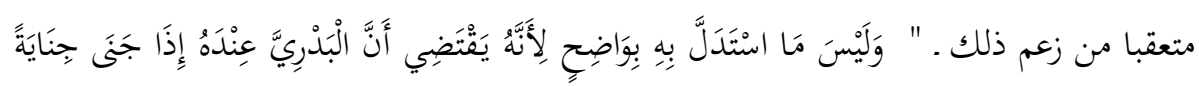

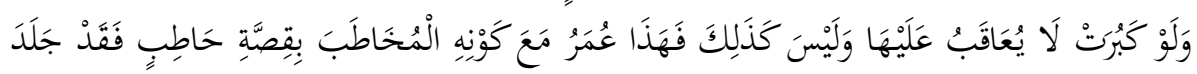

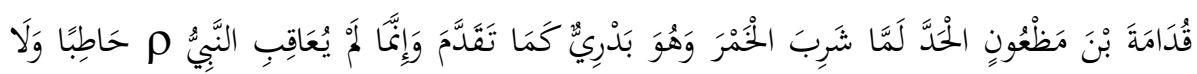

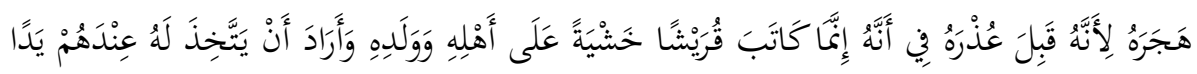

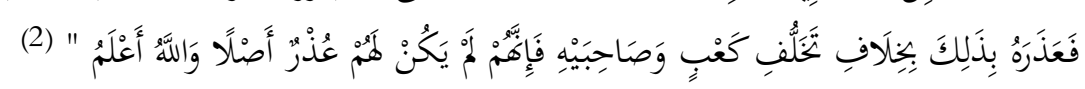

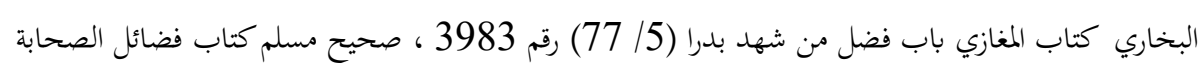

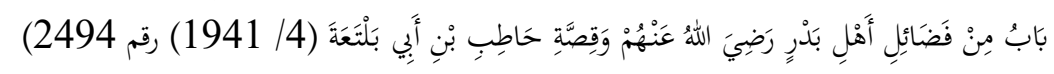




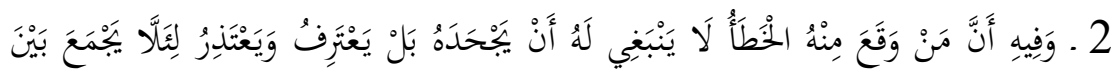

ذَنْبَيْنِ

باب(17) في التثبت والتروي قبل إصدار الحكم على الناس

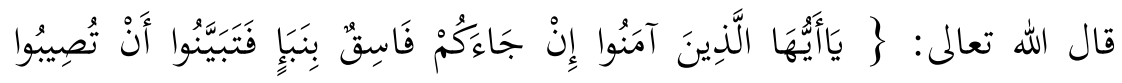

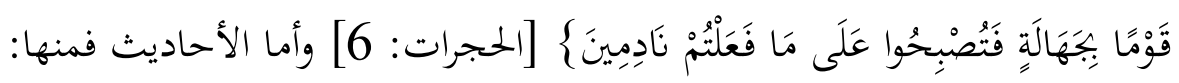

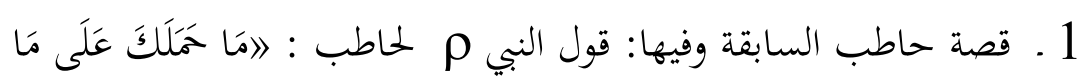

صَنَعْتَ

2 ـ وقول النبي م لكعب بن مالك في قصة تخلفه عن غزوة تبوك : " ما خَلََّكَكَ

(2)

$$
\text { فوائد من الحمديث : فئ }
$$

فيه أن النبي م يتروى ويتبت في الأمور ولا يتسرع في الحكم على الأشخاص ، وهذا تعليم

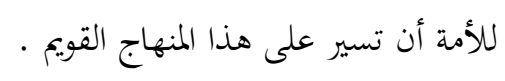

\section{باب (18 ) في في النبي م عن الاعتداء والتجاوز في العقوبة}

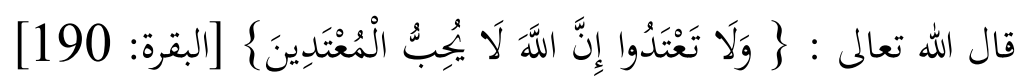

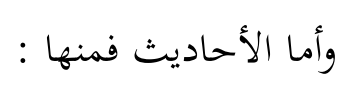

1. ما أخرجه مسلم في قصة الغامدية التي رجمت وفيها ،" وَأَمَرَ النَّاسَ

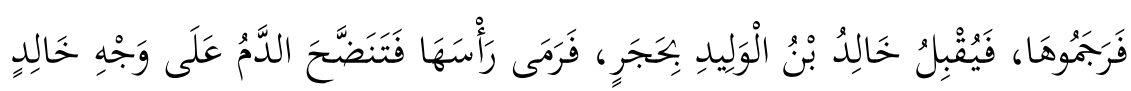

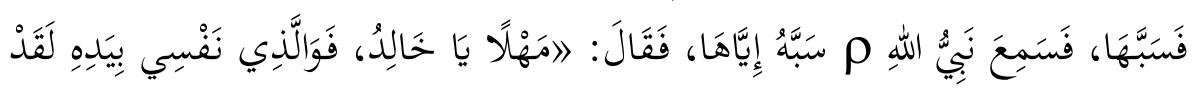

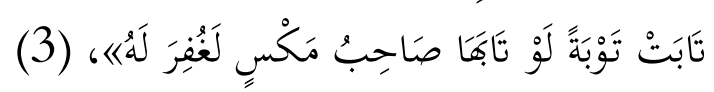

$$
\text { (1) فتح الباري لابن حجر (12/ (12) }
$$

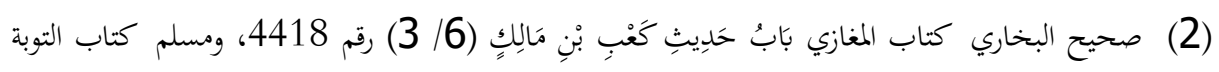

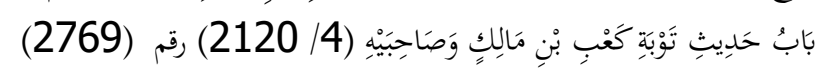

(3) سبق تخريكهاص 


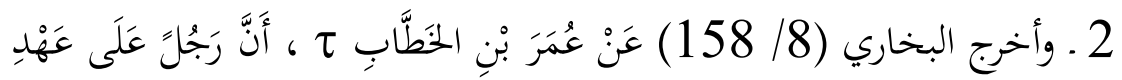

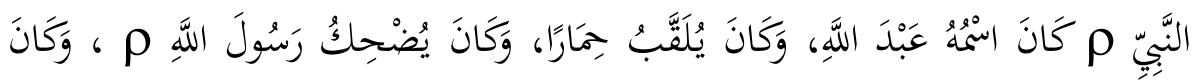

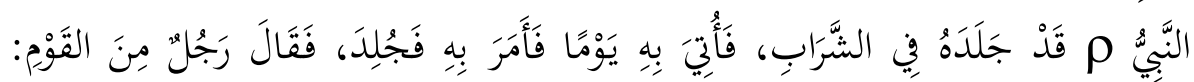

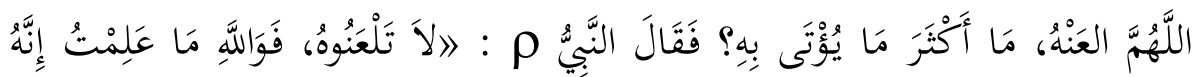

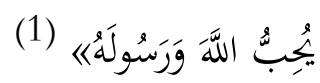

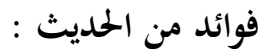

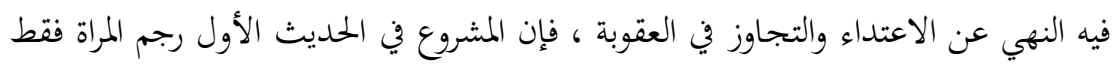

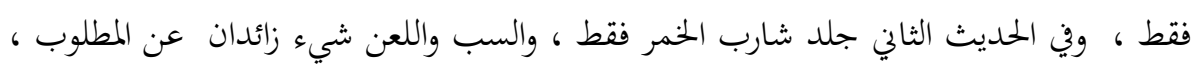

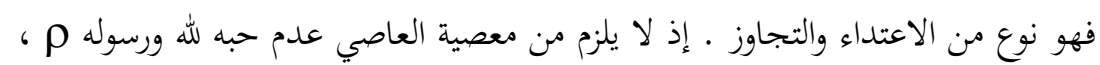

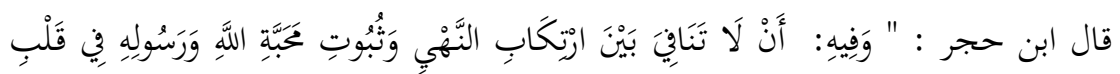

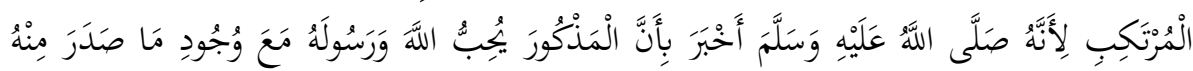

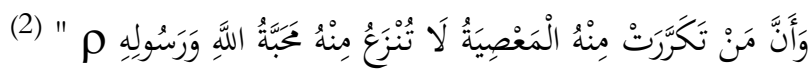

\section{باب(19) في مخاطبة الببي م العقل والعاطفة للإقناع بالحكم الشرعي}

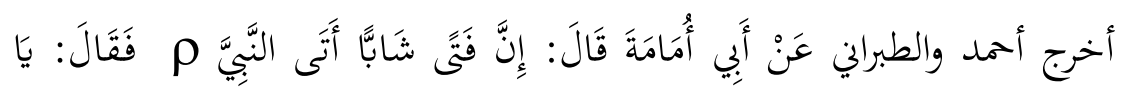

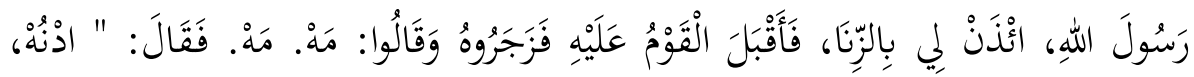

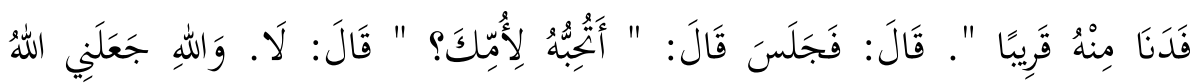

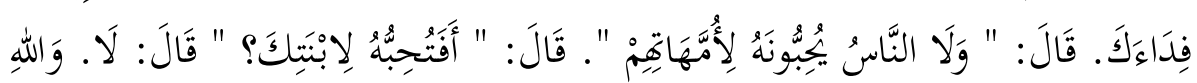

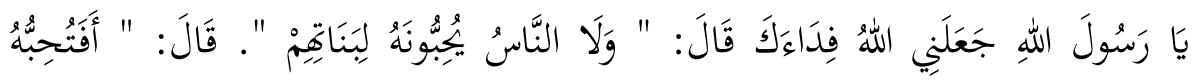

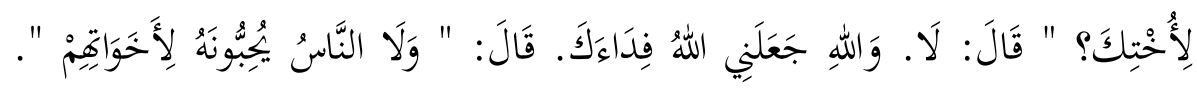

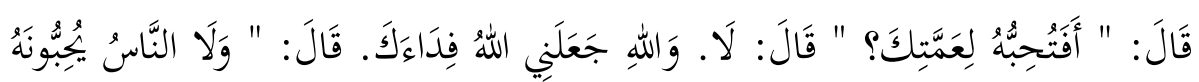

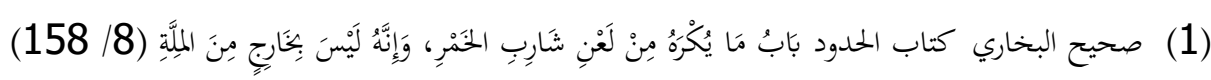

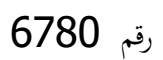
(2)فتح الباري لابن حجر (78/12/ 


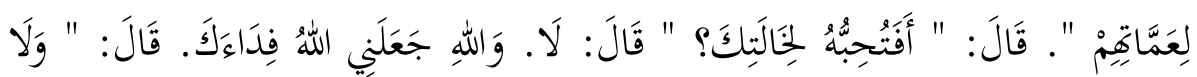

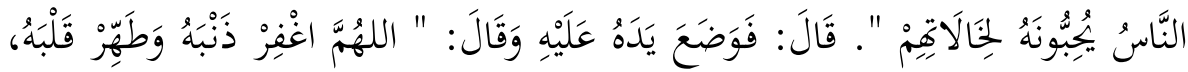

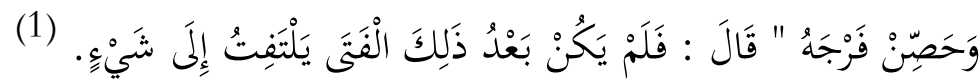

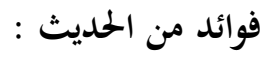
فيه بيان لمنهج النبي م العظيم في إقناع الشاب بحرمة الزنا فلم يسرد عليه آيات تحريم الزنا

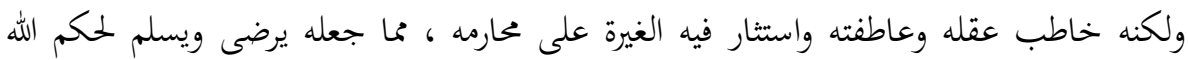
ورسوله

باب(20) في اتباع النبي م منهج الترغيب والترهيب

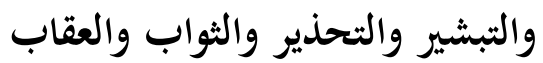

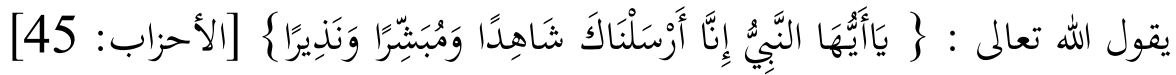

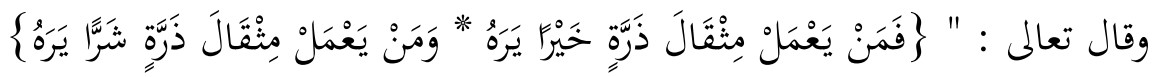

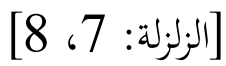
وأما الأحاديث فأكثر من أن تخصى منها :

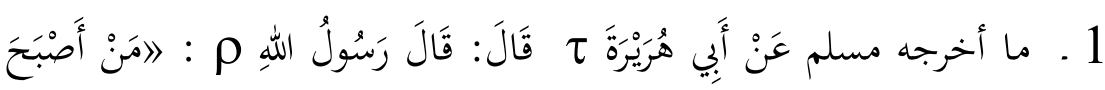

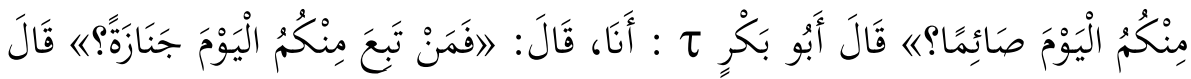

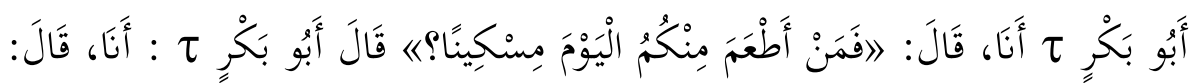

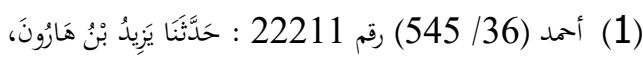

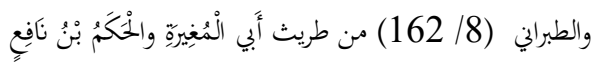

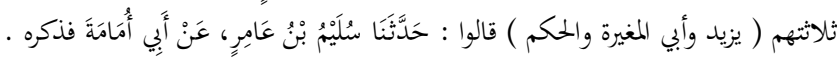

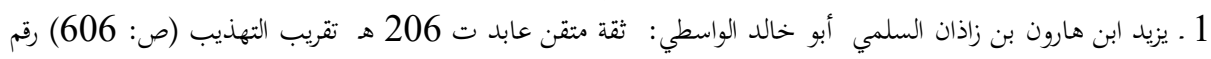
7789 2. سليم ابن عامر الكلاعي ويقال الخبائري [بخاء معجمة وموحدة] أبو يهيى الحمصي: ثقة من الثالثة غلط من قال إنه أدرك

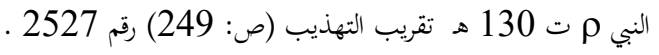
3 أبو أمامه الصحابي المشهور

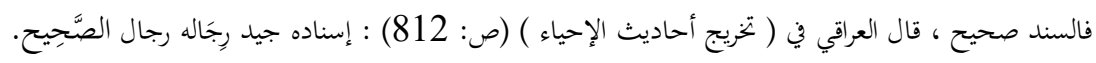




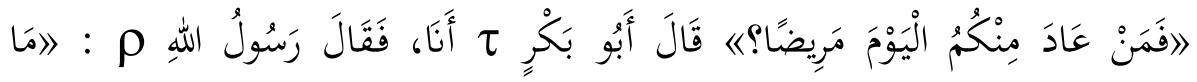

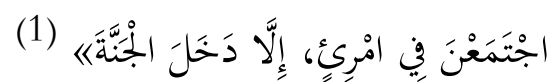

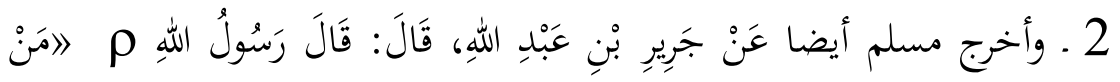

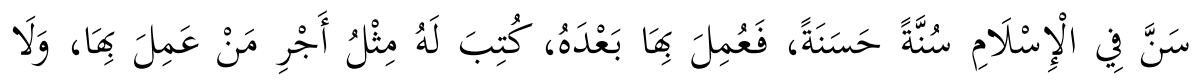

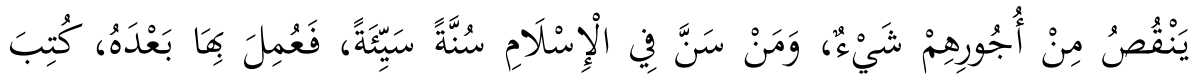

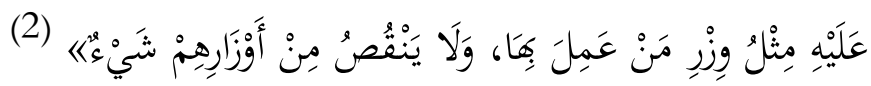

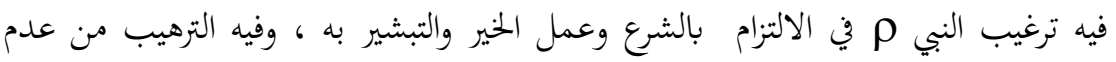

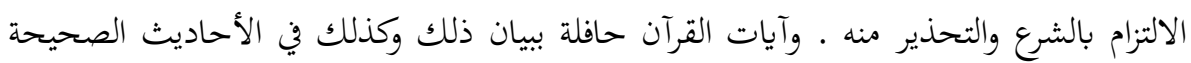

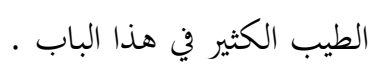
وإلى هنا أكون قد وصلت إلى خاية البحث داعيا الله أن يتقبله مني بقبول حسن وأن يعفو

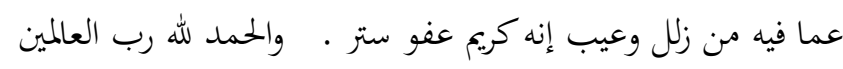

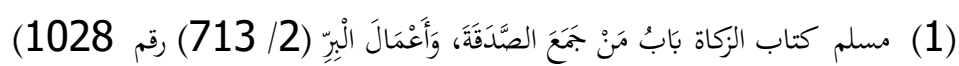

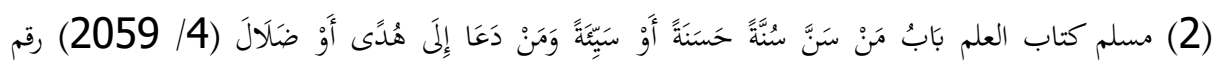




\section{خاتمة البحث وتوصياته}

الحمد لله الذي بنعمته تتم الصالحات ، والصلاة والسلام على سيد الخلق وحبيب

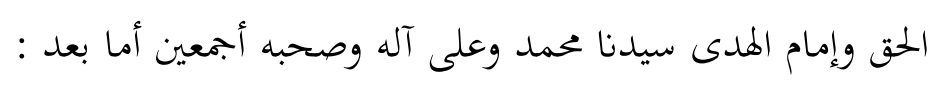

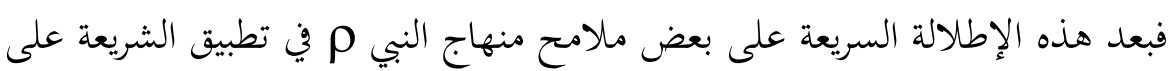

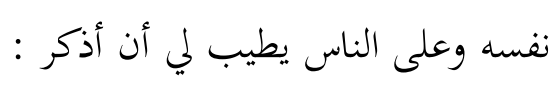
أهم النتائج التي توصلت إليها وهي

1 ـ أن النبي م هو أرقى أنموذج بشري عرفته الدنيا في تطبيق الشريعة التي جاء هما

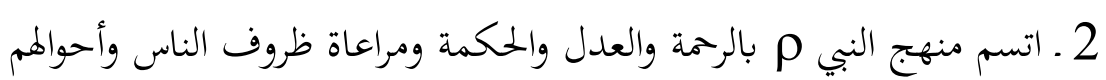

3 . حياة النبي م صفحة بيضاء ليس فيها مخالفة ولا شائبة .

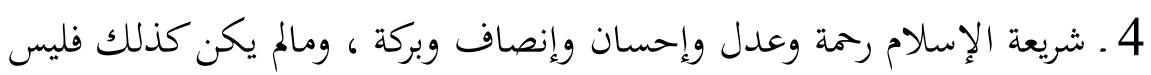
من الشريعة في شيء

5 ـ العيب في المسلمين الذين لم يحسنوا تطبيق الشريعة وليس في الشريعة ذاتحا .

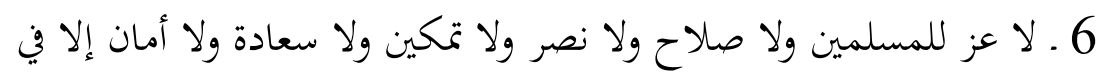

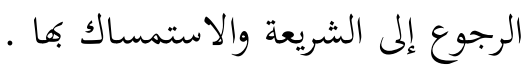

7 ـ الإشكالية الفكرية هي في عدم التفريق بين المسلمين والإسلام ، أو بين الشرع

$$
\begin{aligned}
& \text { ذاته وسوء الفهم له . لـ إلهاليه } \\
& \text { وأما عن : } \\
& \text { أهم التوصيات : }
\end{aligned}
$$




$$
\begin{aligned}
& 1 \text { ـ أوصي بأن يتم دراسة المنهج النبوي في تطبيق الشريعة بشكل أوسع في صورة } \\
& \text { رسائل جامعية أو عقد مؤتمرات للوقوف على الجوانب المشرقة من هدي النبي م في } \\
& \text { ذلك . } \\
& \text { وأسأل الله تعالى أن يعيد الأمة الإسلامية إلى سابق عهدها وعزها إنه ولي ذلك } \\
& \text { والقادر عليه } \\
& \text { وصلى الله وسلم وبارك على سيدنا محمد وآله وصحبه أجمين }
\end{aligned}
$$

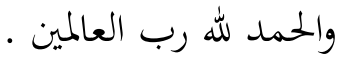




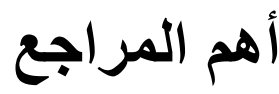

المرجع بن عاصبر

1. الاستذكار: للإمام أبي عمر يوسف بن عبد الله بن عبد البر بن عاصم القرطبي (المتوف: 463هـ)،تحقيق: سالم محمد عطا،

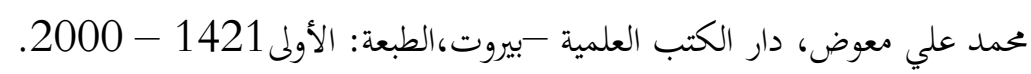

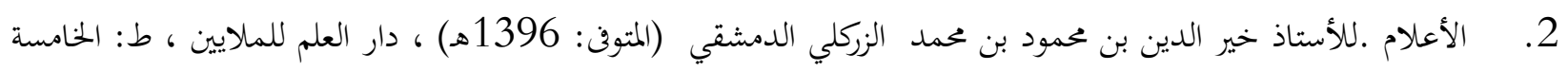

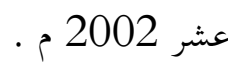

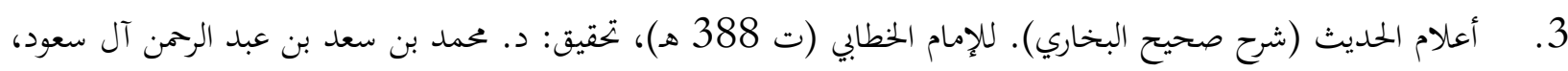

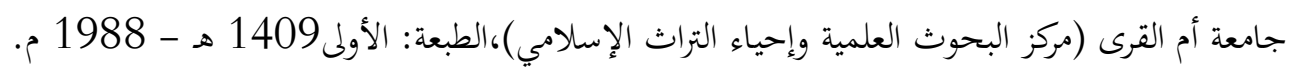

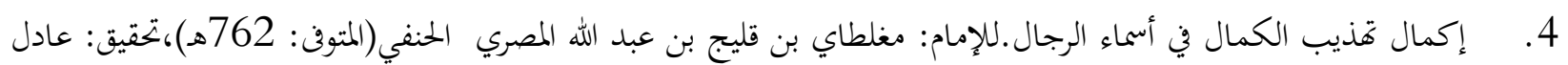

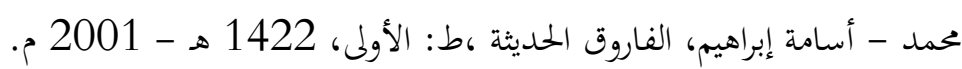

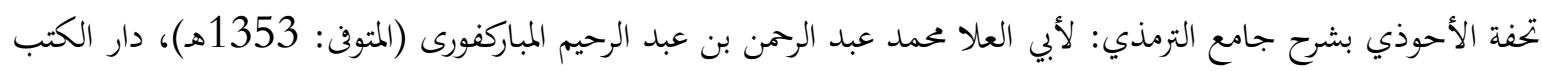
.5 العلمية - بيروت. 6. التعريفات:لإمام علي بن محمد بن علي الزين الشريف الجرجاني (المتوف: 816هـ)، ضبطه وصححه جماعة من العلماء التراء

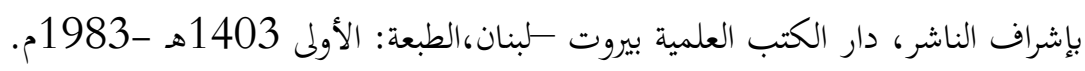

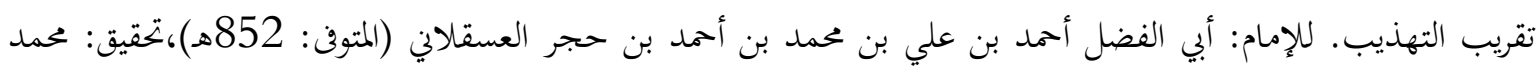
.7

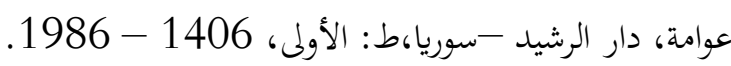

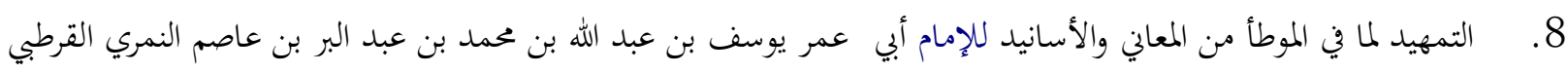

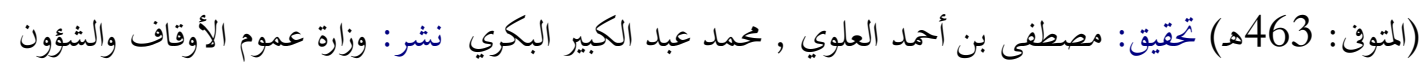

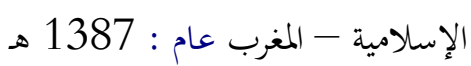

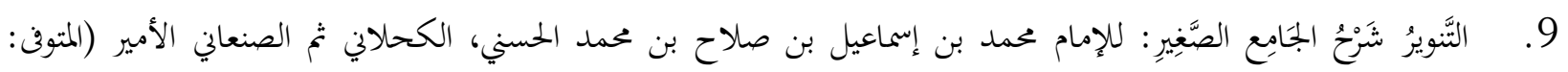

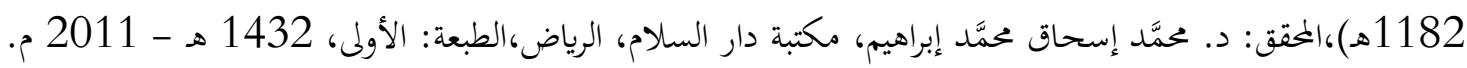

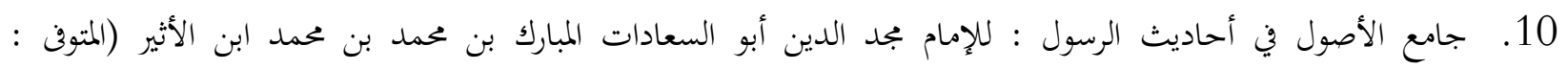

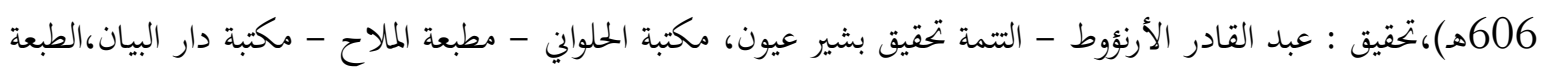

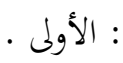




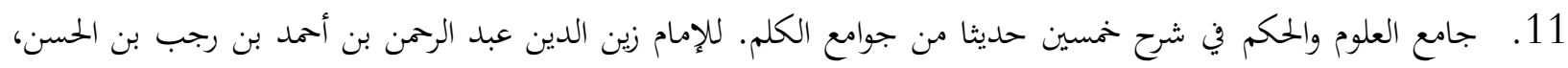

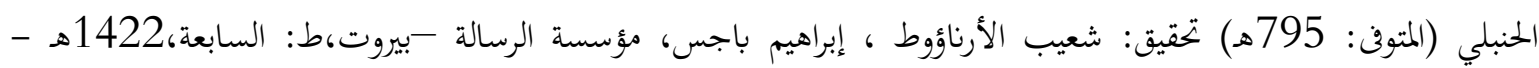
2001

12. د دليل الفالحين لطرق رياض الصالحين: للإمامحمد علي بن محمد بن علان بن إبراهيم البكري الصديقي الشافعي (المتوف:

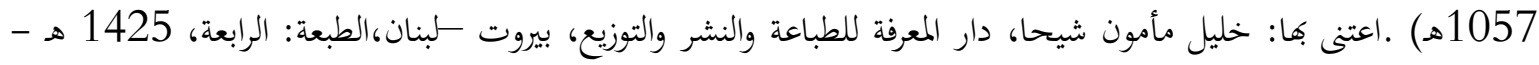
م 2004

رسالة رؤية هلال ذي الحجة من مجموع رسائل الحافظ ابن رجب الحنبلي ، تحقيق: طلعت بن فؤاد الحلواني نشر: الفاروق .13

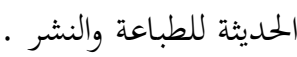

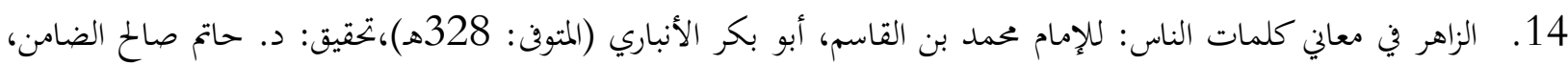

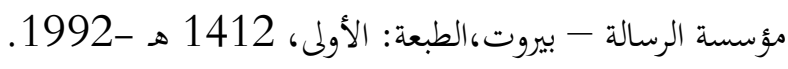

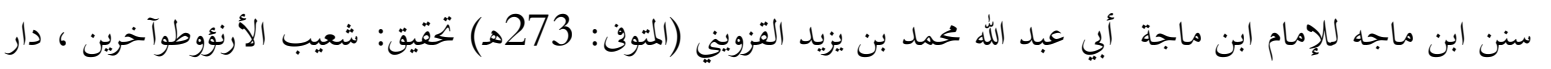
.15

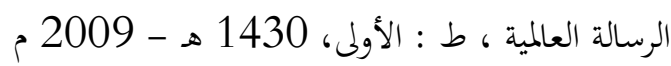

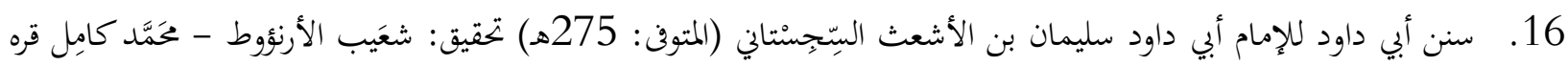

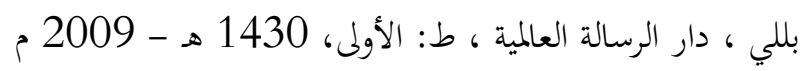

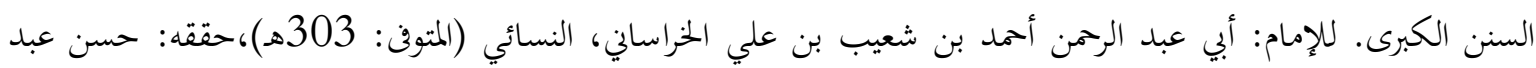

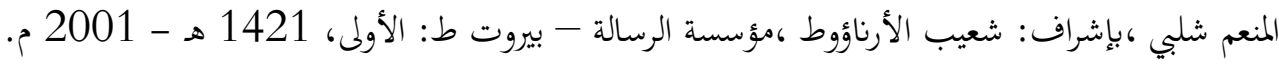

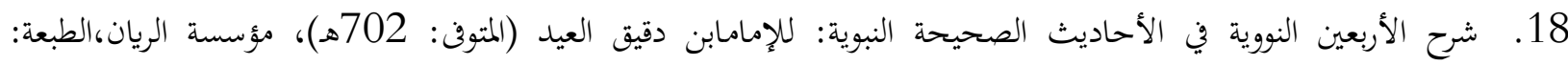
السادسة 1424 هـ - 142003 م. 2003 م.

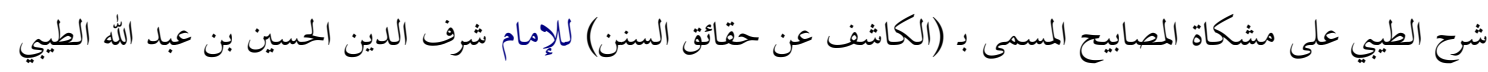
.19

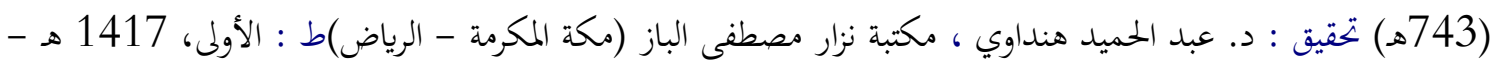

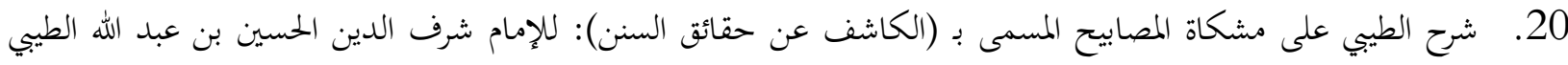

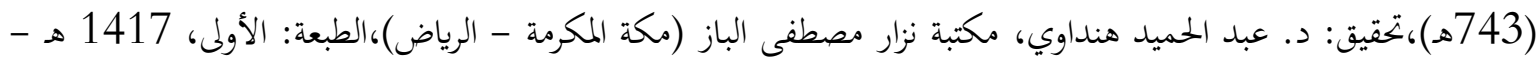
1997

2الصحاح تاج اللغة وصحاح العربية: للإمام الجوهري (المتوف: 393هـ)، تحقيق: أحمد عبد الغفور عطار، دار العلم للملايين .21

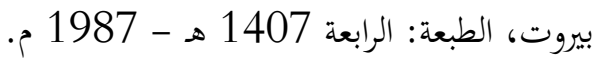


صحيح البخاري للإمام عحمد بن إسماعيل أبو عبد الله البخاري ، تحقيق: محمد زهير بن ناصر الناصر ، دار طوق النجاة ط:

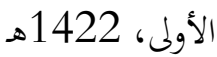

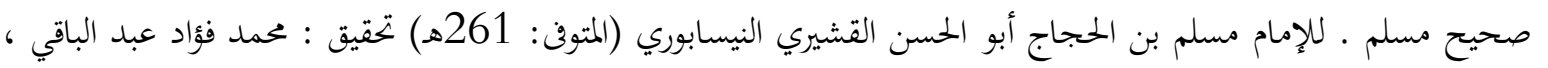

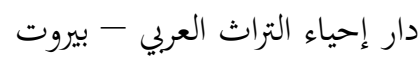

24. عمدة القاري شرح صحيح البخاري. للإمام بدر الدين العينى (المتوف: 855ه)، دار إحياء التراث العربي - بيروت.

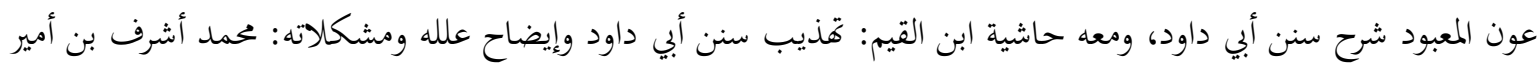

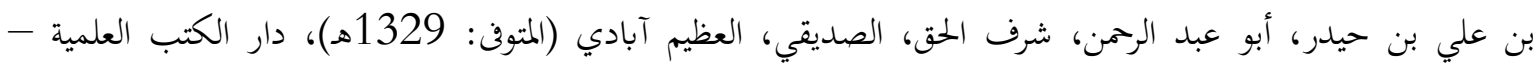

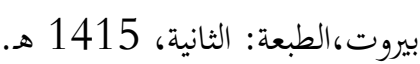

فتح الباري شرح صحيح البخاري.لإإمام: أمد بن علي بن حجر أبو الفضل العسقلاني الشافعي، دار المعرفة - بيروت،

لسان العرب للإمام محمد بن مكرم بن على، أبو الفضل، جمال الدين ابن منظور الأنصاري الإفريقى (المتوف: 711هـ) دار

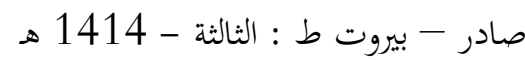

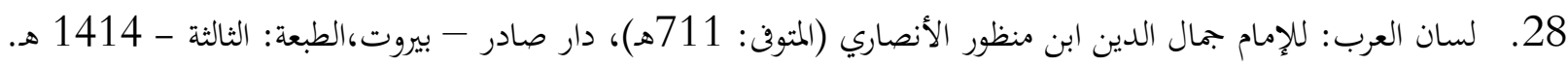

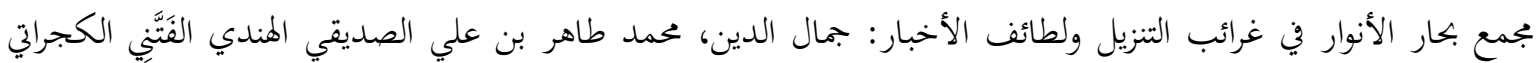

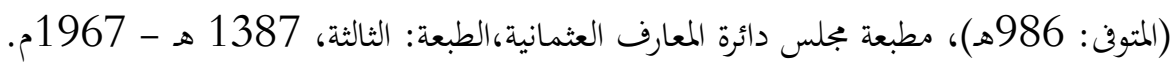

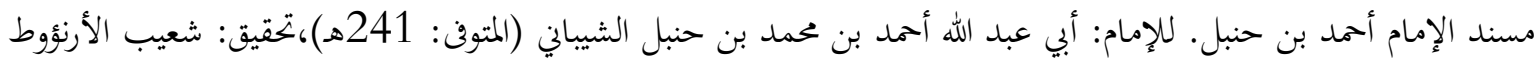

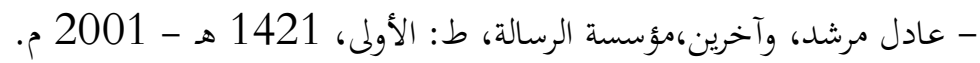

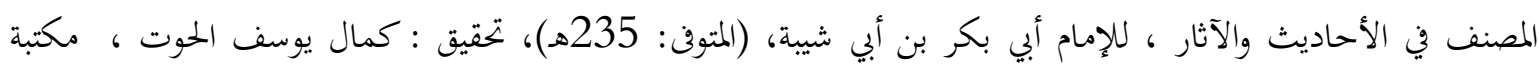

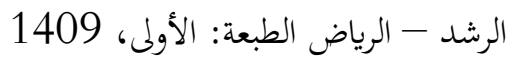

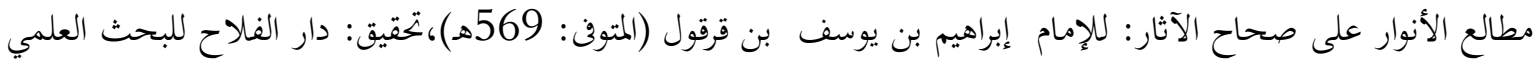

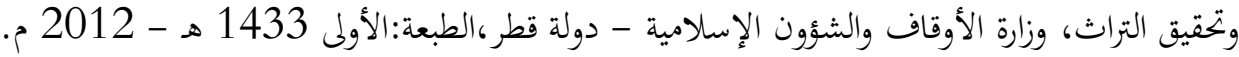

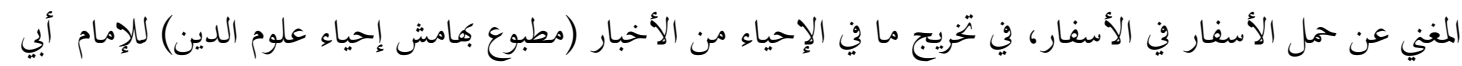

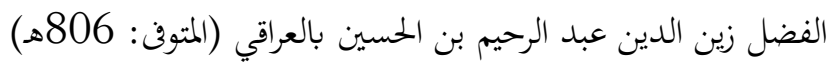

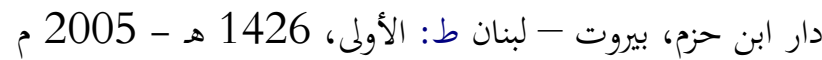

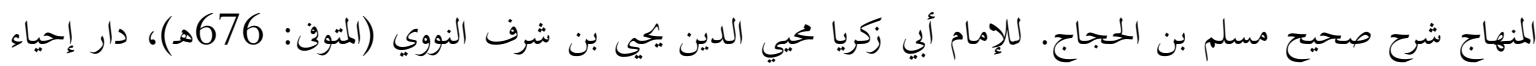
.34 التراث العربي - بيروت،الطبعة: الثانية، 1392. 
35. المنهاج شرح صحيح مسلم بن الحجاج.لإمام: أبي زكريا محيي الدين يهيى بن شرف النووي (المتوف: 676هـ)، دار إحياء

التراث العربي - بيروت،طئ الثانية، 1392.

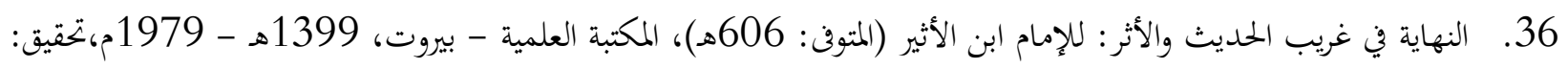

طاهر أممد الزاوى - محمود محمد الطناحي.

37. النهاية في غريب الحديث والأثر:للإمام بحد الدين ابن لأئير (المتوف: 606هـ)، المكتبة العلمية - بيروت، 1399هـ -

1979م.تحقيق: طاهر أحمد الزاوى - محمود محمد الطناحي. 